العدد التاسع عشر لسنة 2018

667

مجلة البحث العلمى فى التربية

دراسة تحليلية لبعض أساليب ووسائل التربية والتعليم في السنة النبوية وتطبيقاتها التربوية

أ/ وفاء عبد الرحمن الرميح 


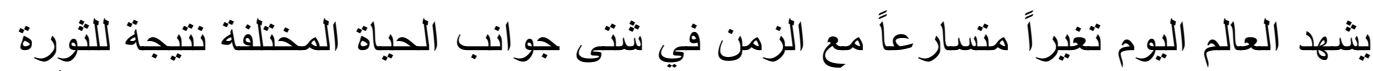

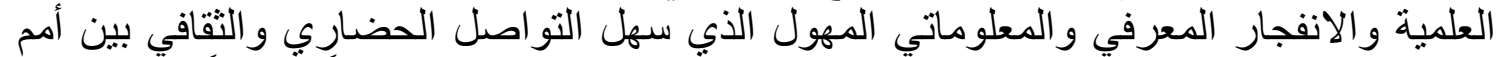

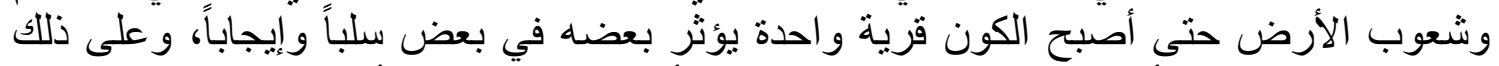

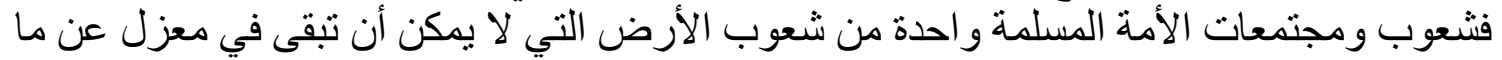

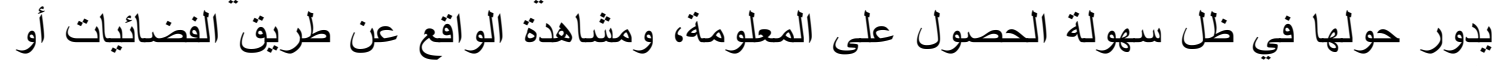
الثبكة العنكبوتية العالمية.

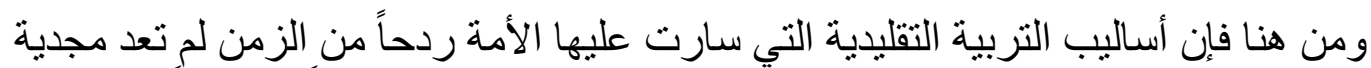

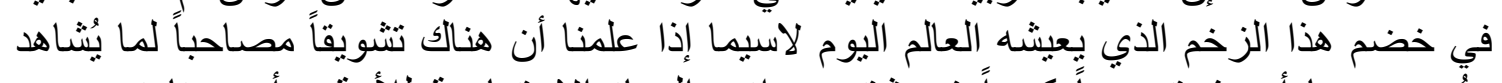

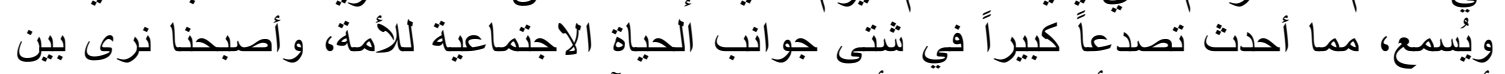

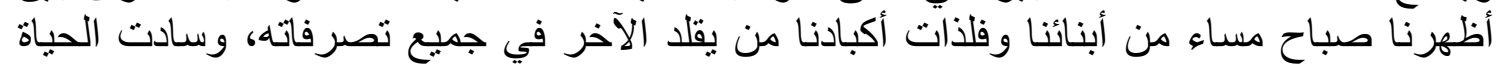

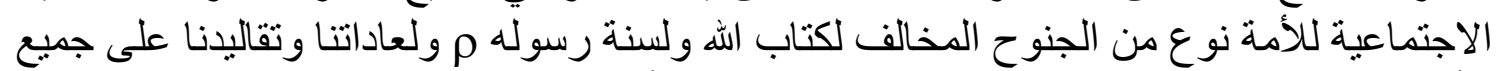

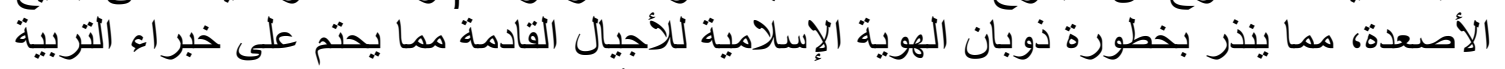

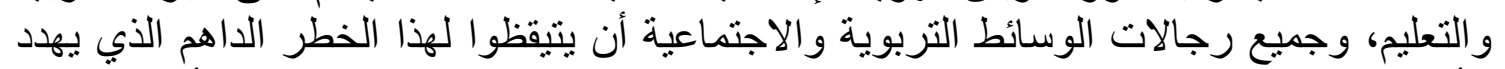

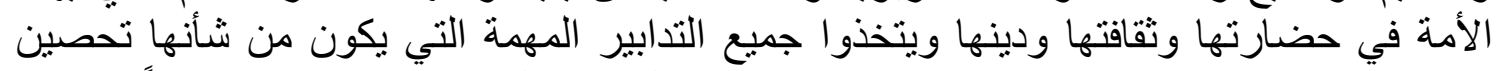

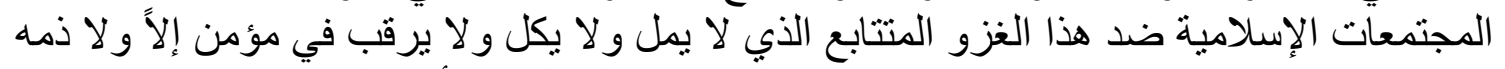

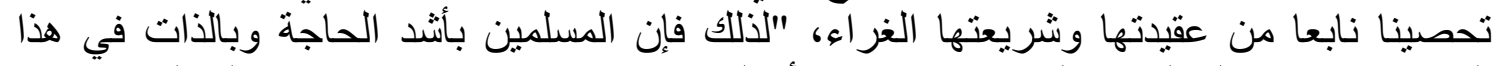

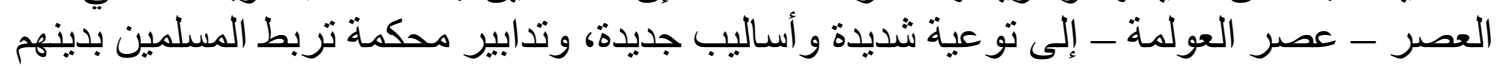

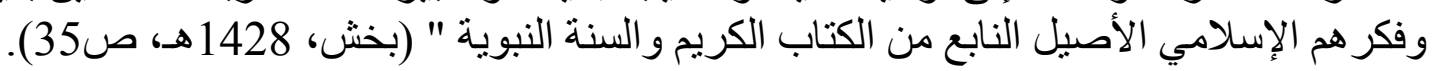

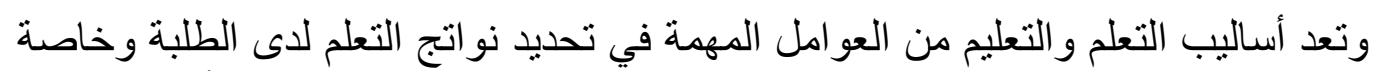

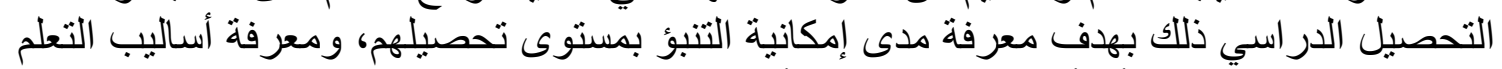

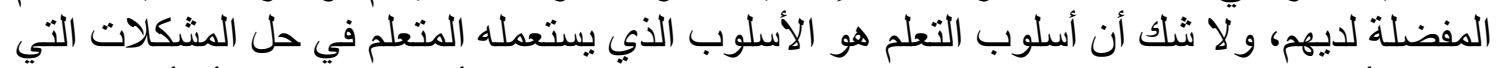

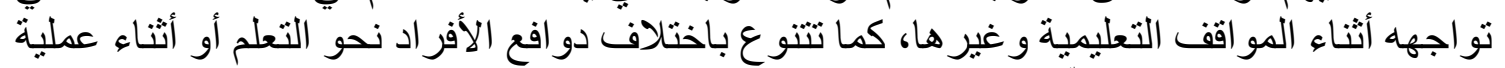

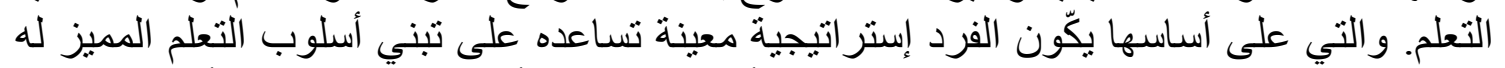

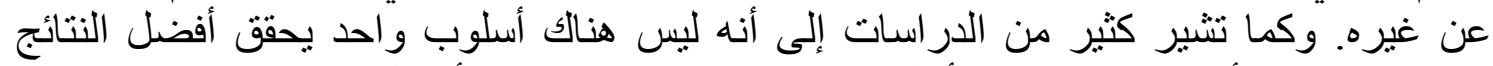

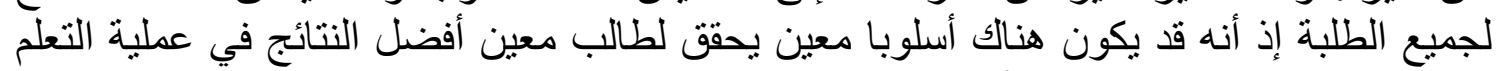

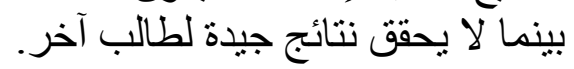

إن البحث في أساليب التعلم يعد اتجاها مهماً في مجال علم النفس التربوي و بخاصة عندا عندما

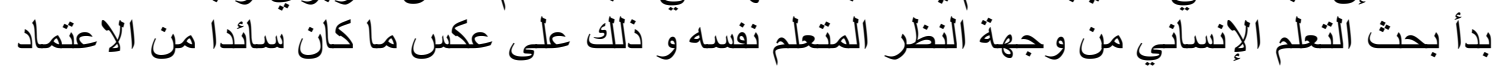

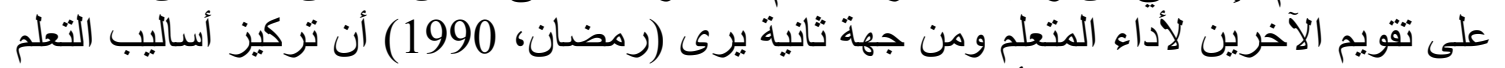

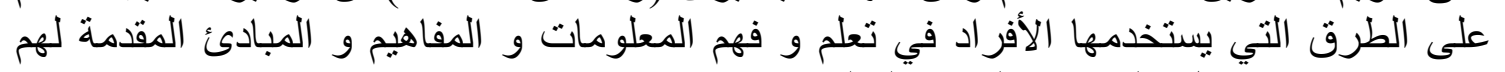
عكس ما كان من فبل بالتركيز على كم التعلم.

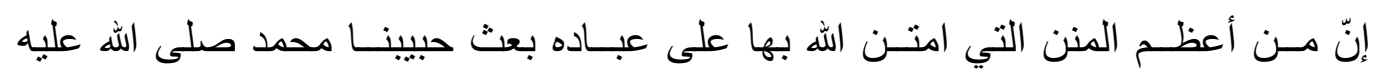

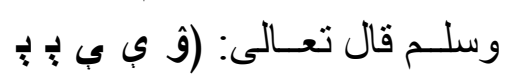

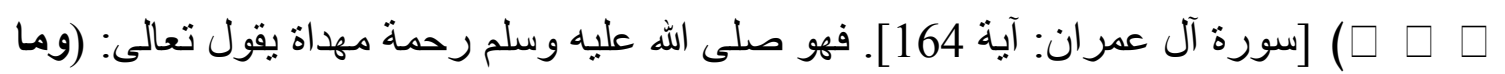

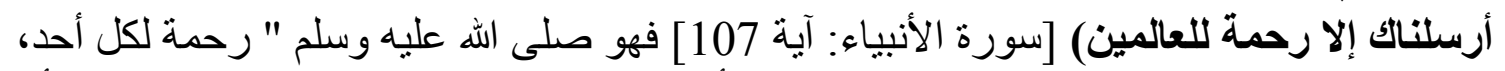

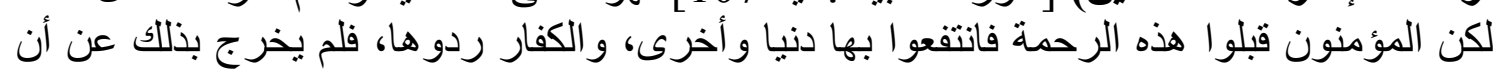

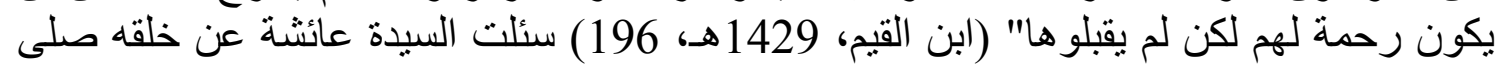


الله عليه وسلم فقالت " كان خلقه القرآن" (ابن رجب، 1408هـ، 148) فهذا وصف جامع مانع

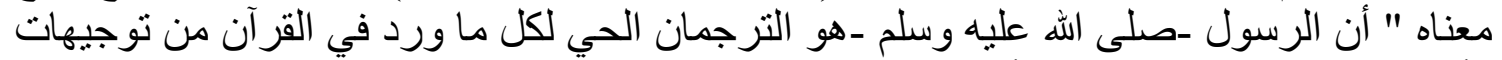

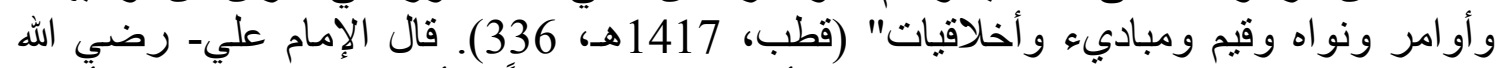

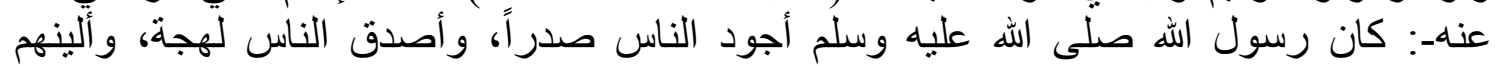

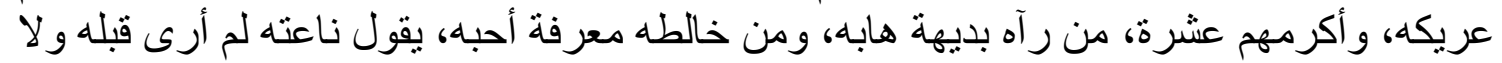

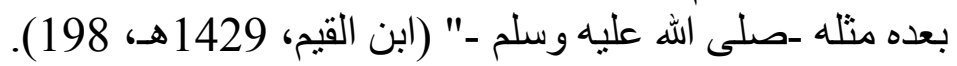

وفي السنة النبوية المطهرة أوضح سيد البشرية ومعلم الإنسانية صلى الله عليه وسلم أهمية

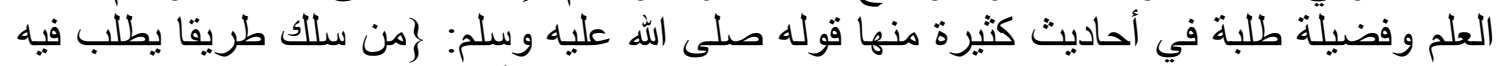

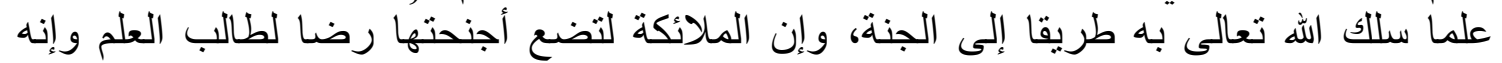

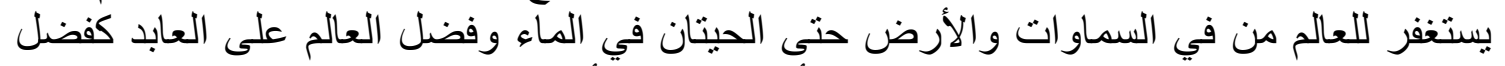

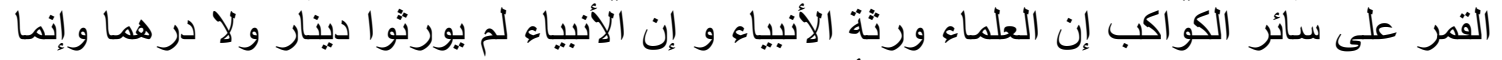

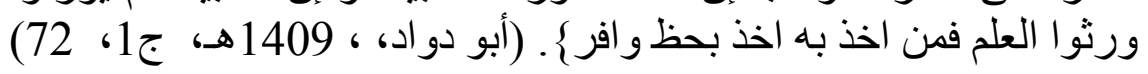

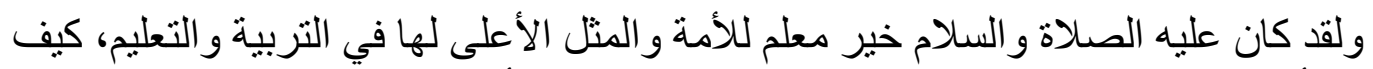

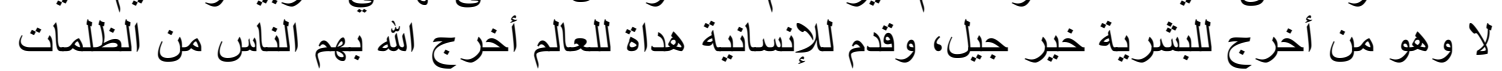

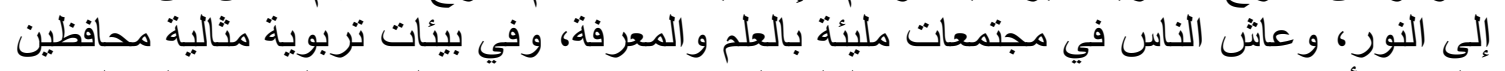

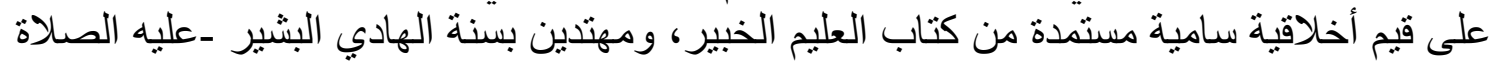

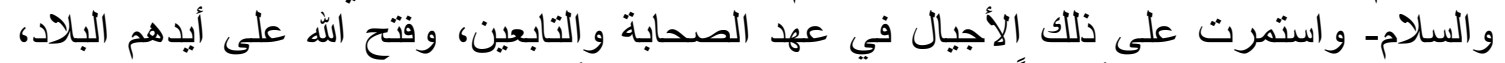

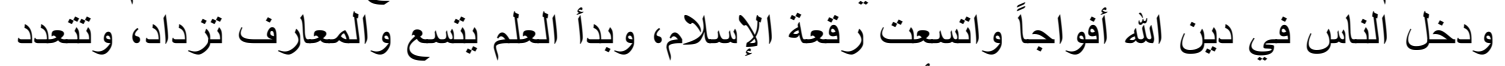

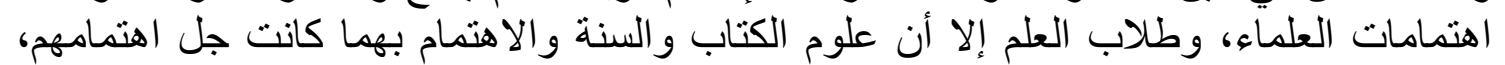
و التي منها ينطلقون للعلوم الأخرى.

وقد حققت أساليب ووسائل التربية الإسلامية نتائج نربوية عظيمة انعكست آثار ها على فلى

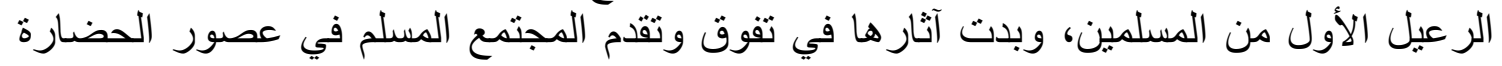

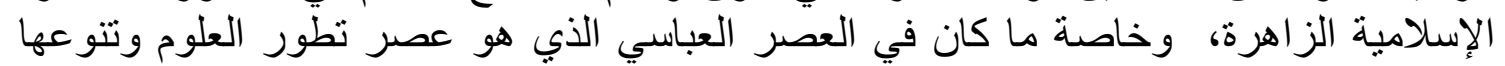

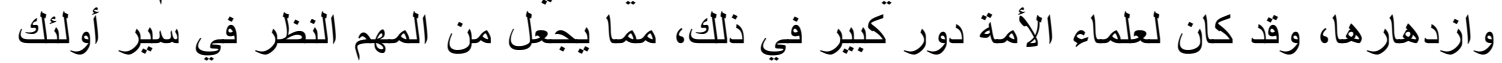

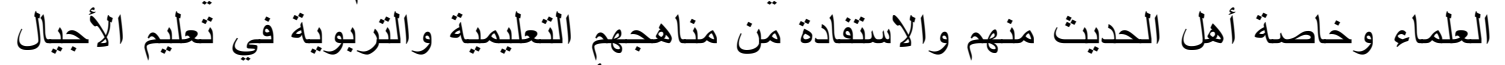

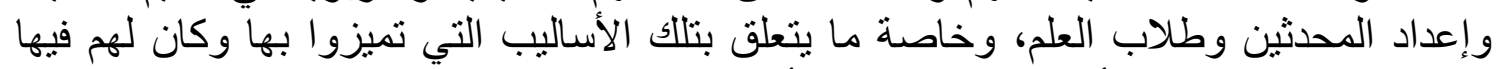

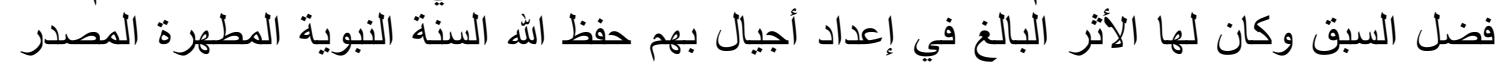

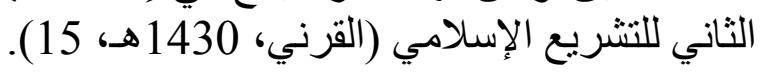

$$
\text { قضية الدراسة: }
$$

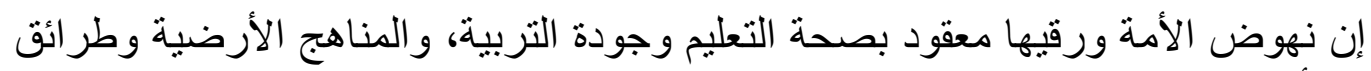

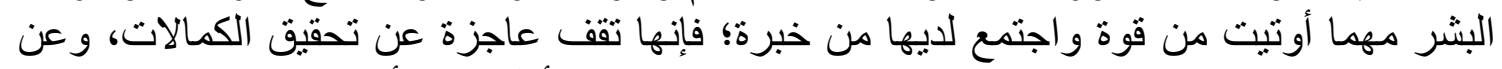

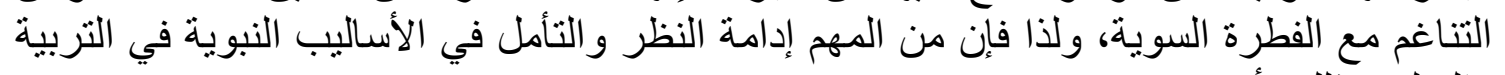
و التعليم وذللك لأمور: الفرة

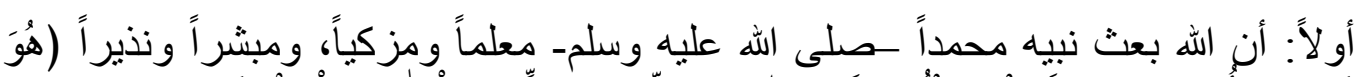

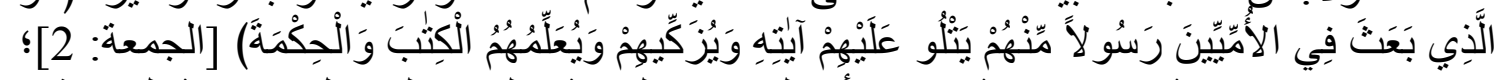

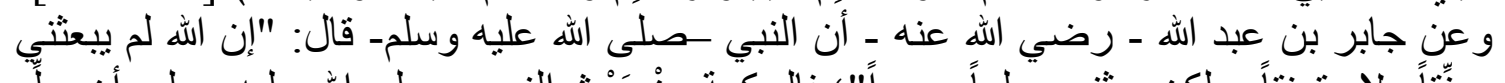

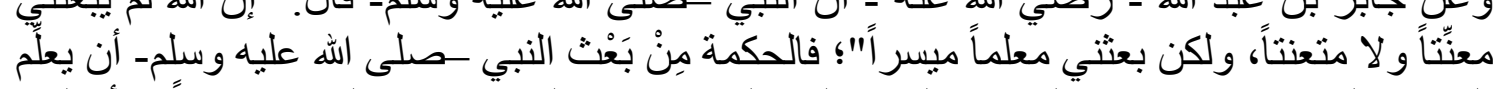

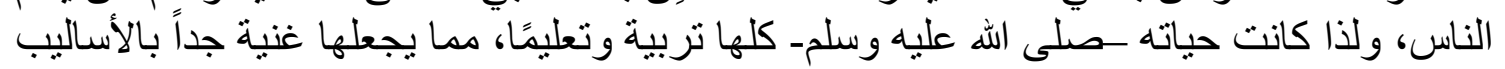


ثانياً: أن النبي ــلى الله عليه وسلم- أوتي الكمال البشري، وعُصم من الخطأ الذي يقدح

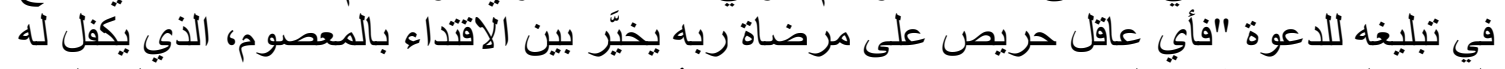

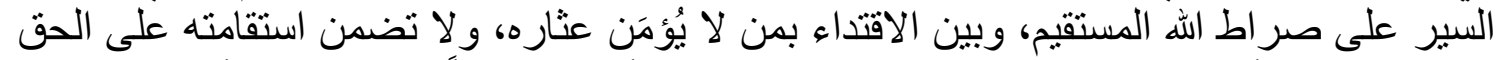

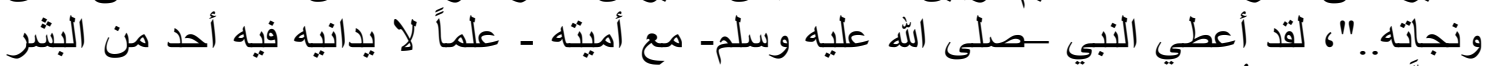

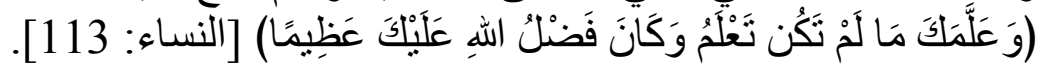

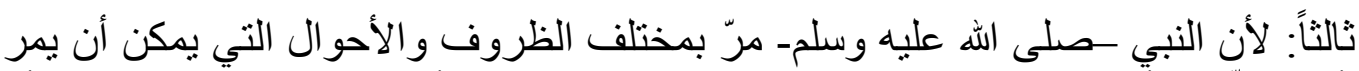

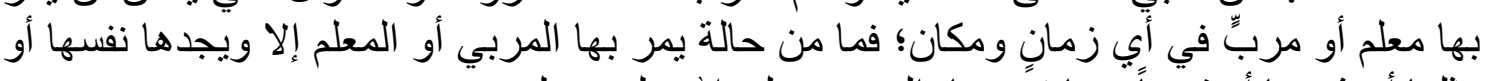

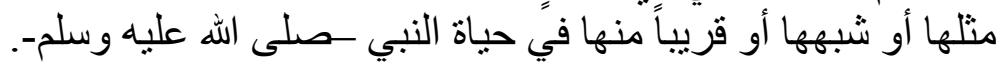

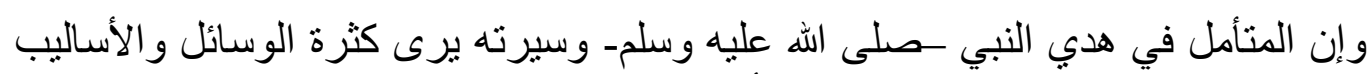

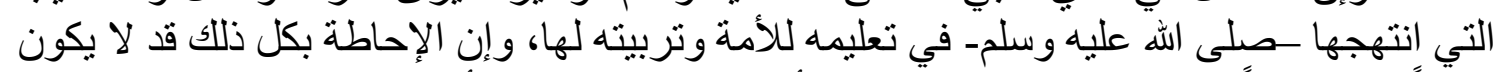

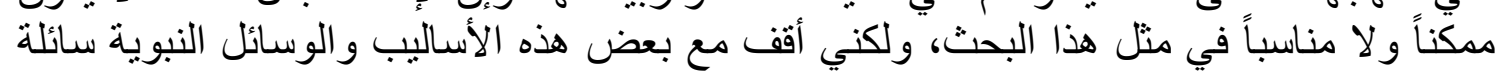
المولى التوفيق و السداد.

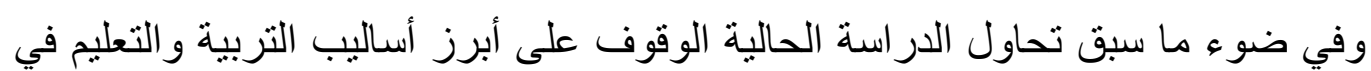

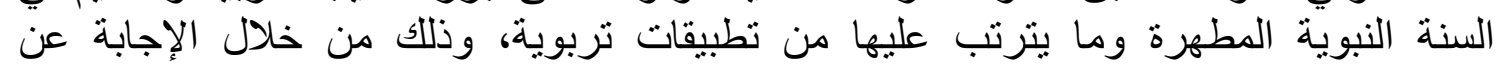
التساؤ لات التالية:

أسئلة الدراسة:

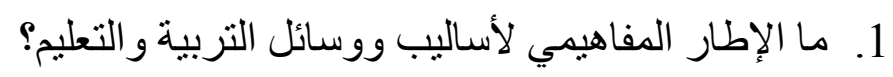

2. ما أبرز أساليب التربية التعليم في السنة النبوية وتطبيقاتها التربوية؟

3. ما أبرز وسائل التربية والتعليم في السنة النبوية وتطبيقاتها التربوية؟؟

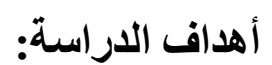

تهدف الدر اسة إلى إبراز أساليب التربية والتعليم في السنة النبوية وتطبيقاتها التربوية وذلك

من خلال تعرف ما يلي: 1. الإطار المفاهيمي لأساليب ووسائل التربية والتعليم.

2. أبرز أساليب التربية التعليم في السنة النبوية وتطبيقاتها التربوية.

3. أبرز وسائل التربية و التعليم في السنة النبوية وتطبيقاتها التربوية.

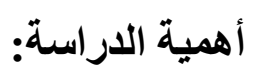

تتطلق أهمية الدراسة من عدة اعتبار ات يمكن إيجاز ها على النحو التالي:

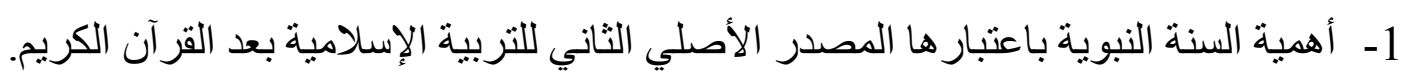

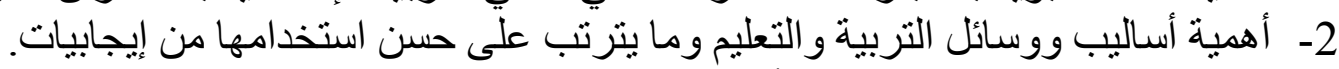

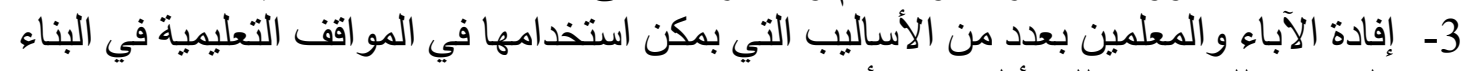

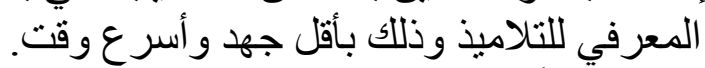

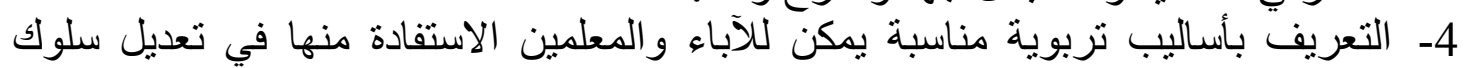

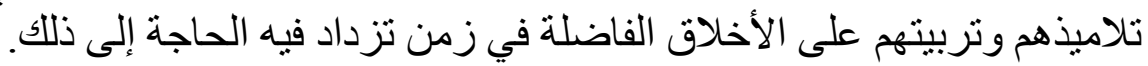


5- إبراز الأساليب التربوية من السنة النبوية التي تساعد المربين و الإداريين على تحقيق أهدافهم

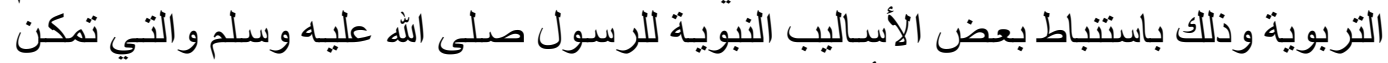
المعلم من بناء النشء المسلم على أسس تربوية إسلامية.

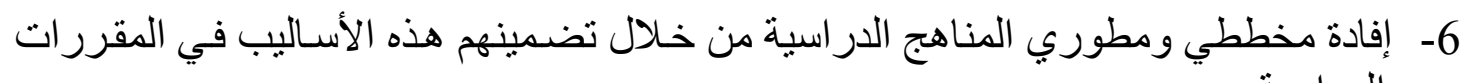

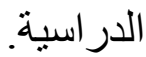
منهج الدراسة: تستخدم الدراسة المنهج الأصولي وذللك بالرجوع إلى إلى السنة النبوية المطهرة ومحاولة استنباط من بها من أساليب ووسائل تربوية وما يترتب على ذلإلك من تطبيقات تربوية. مصطلحات الدراسة:

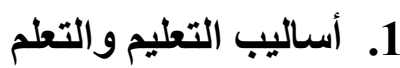
يعرف البعض أساليب التعلم بأنها الخصائص المعرفية و الانفعالية و السمات النفسية الثابتة

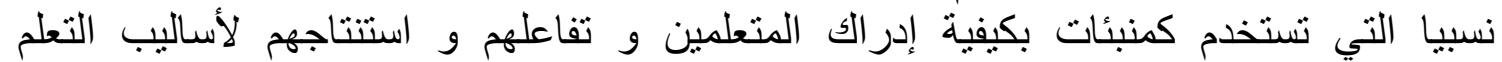

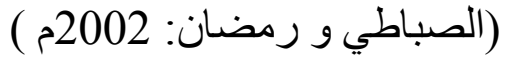

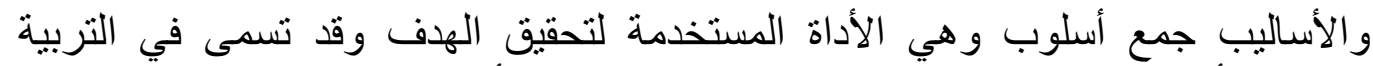

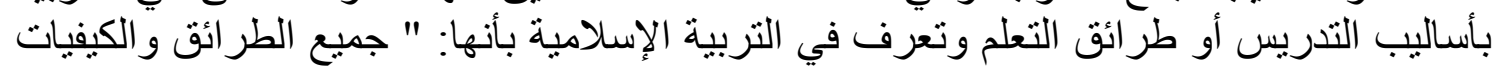

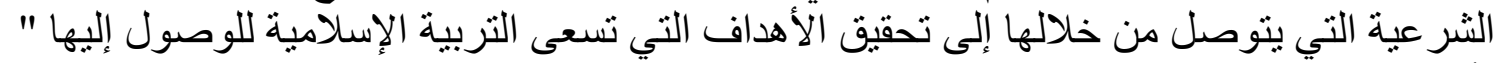

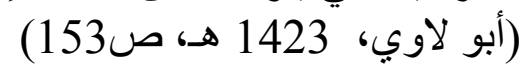

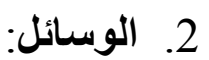

هي الأدوات المعينة على توصيل المعلومة للمتعلم سواء كانت مادية أو معنوية (البيانوني، 1415هـ، 283).

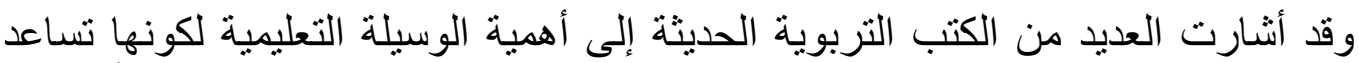

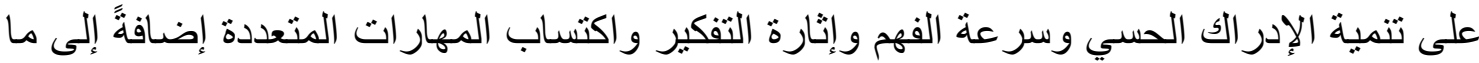
تقدمه الوسيلة، من فرصة لترسيخ عناصر الدرس في أذهان الطلاب.

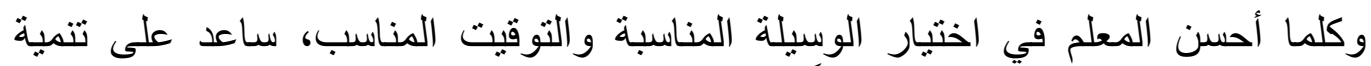

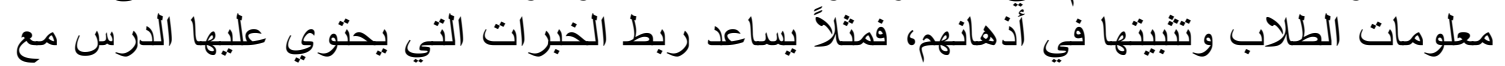

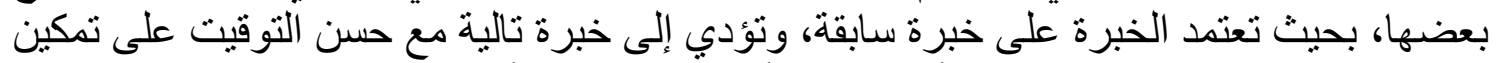

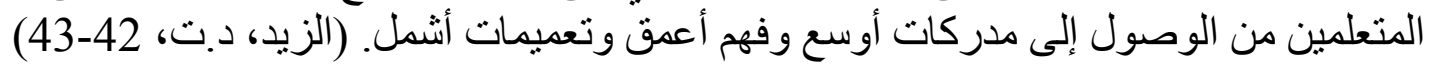

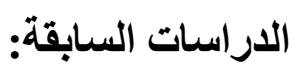

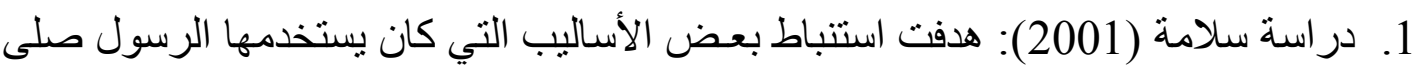

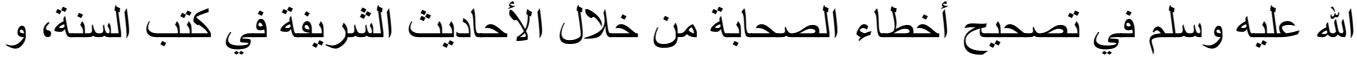

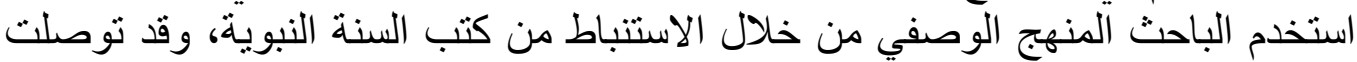

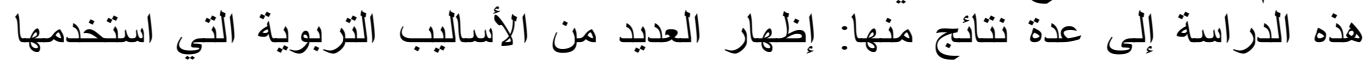

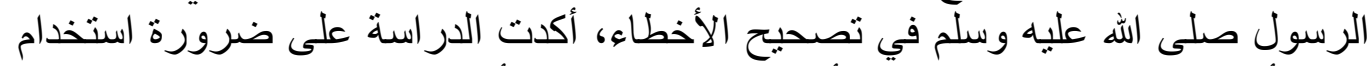
هذه الأساليب في العصر الحاضر لأننا بحاجة للارتقاء بالأساليب التربة التربوية للمربين.

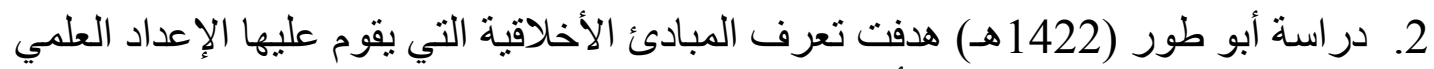

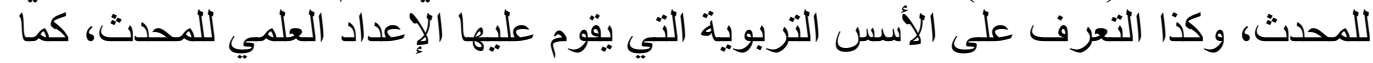


تكلم الباحث عن جهود المحدثين في التدوين في القرن الثالث، و وعن معايير نقد الرواة،

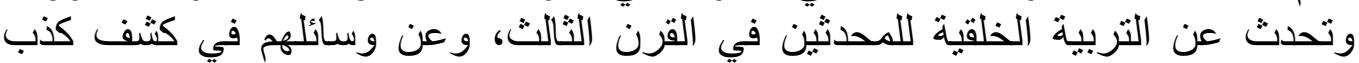

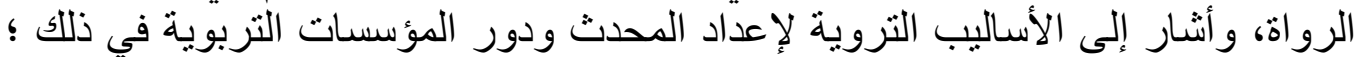

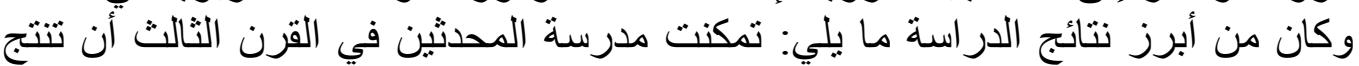

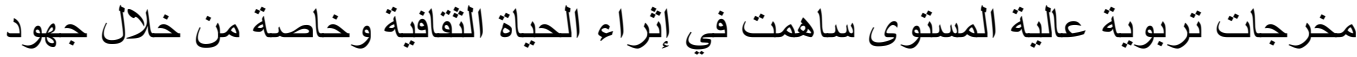

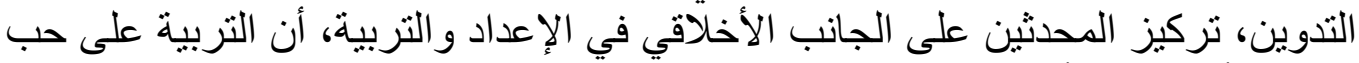

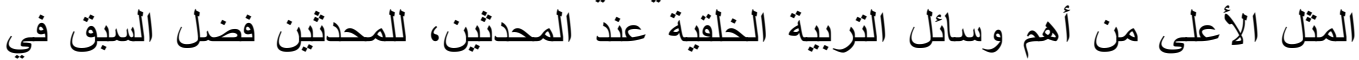

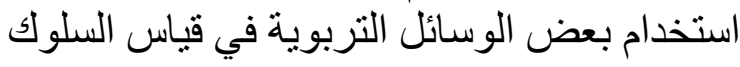

3. دراسة القرني (1424هـ): هدفت توضيح مفهوم وخصائص الضبط الاجتماعي في

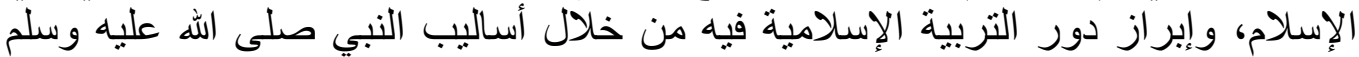

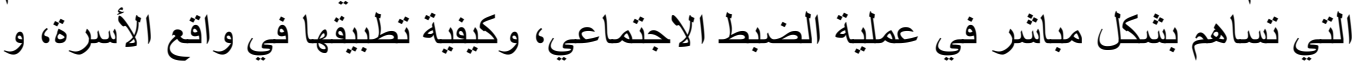

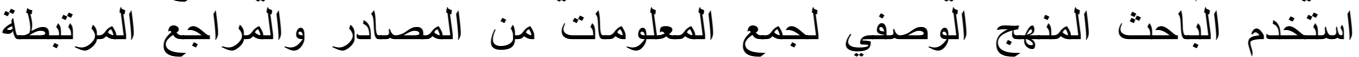

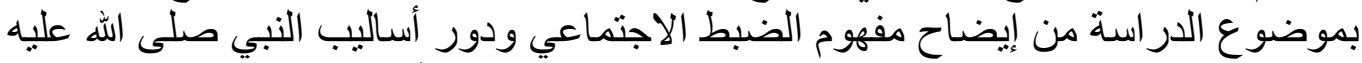

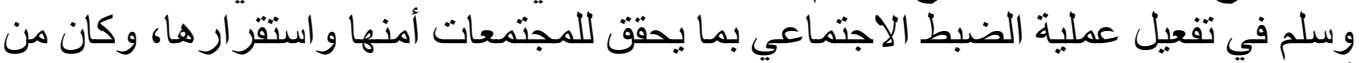

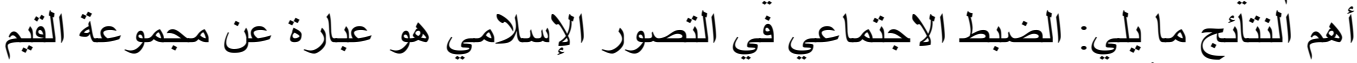

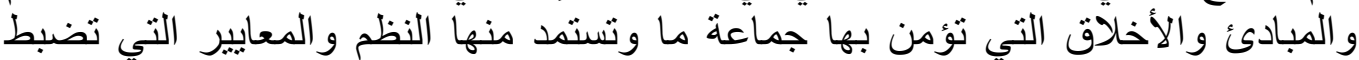

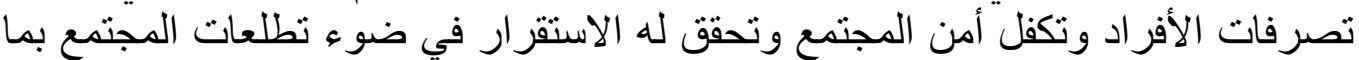

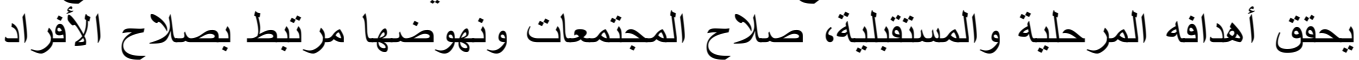

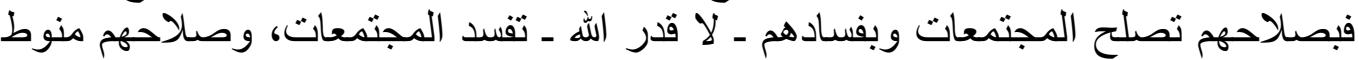
بصلاح تربيتهم وتعليمهر، فقل لي: أي تربية وتعليم تتلقاه؟! أقول للك: من أنتص؟، الأساليب

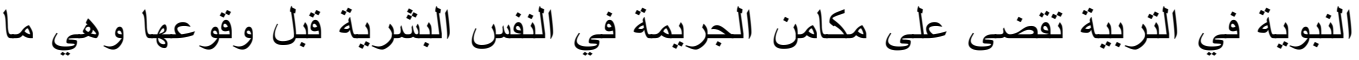

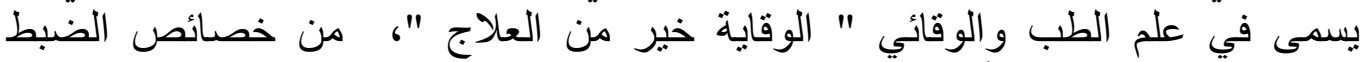

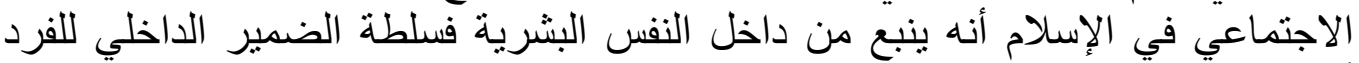

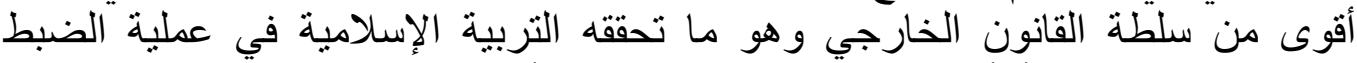

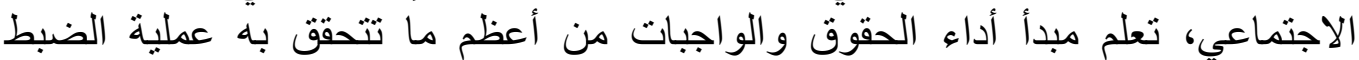

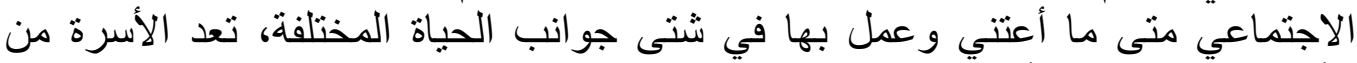
الأهمية بمكان لتفعيل أساليب النبي صلي ألهي الله عليه وسلم في عملية الضبط الاجتماعي.

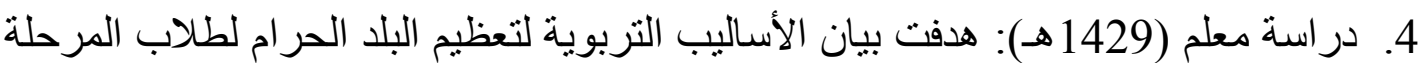

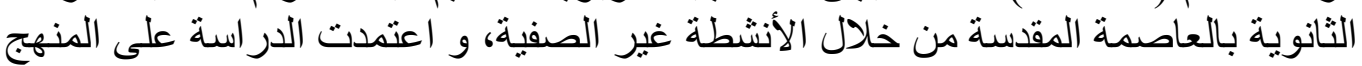

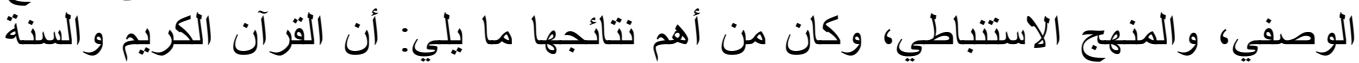

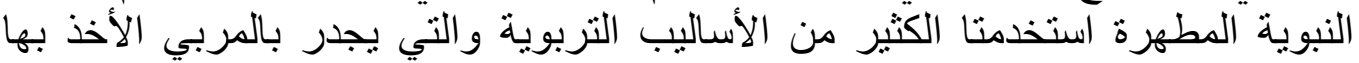

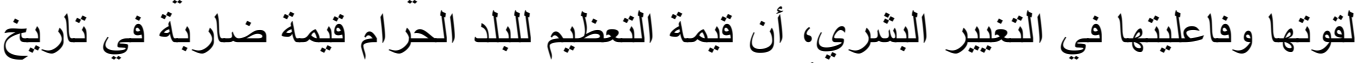

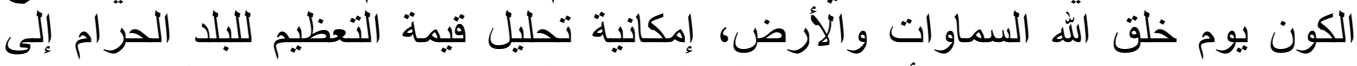

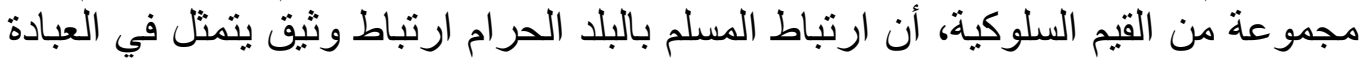

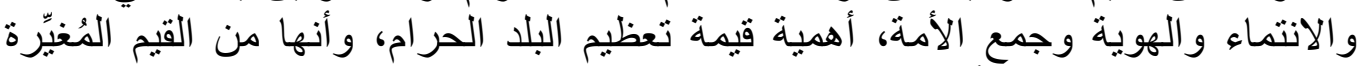

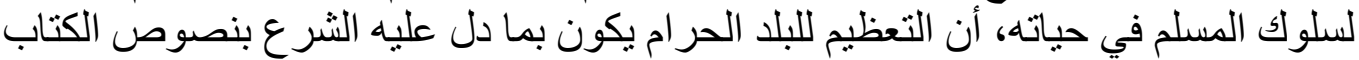

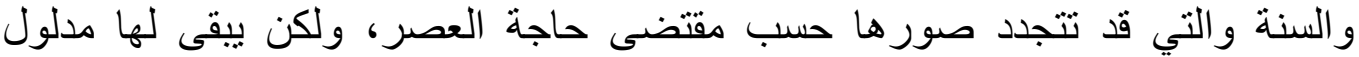

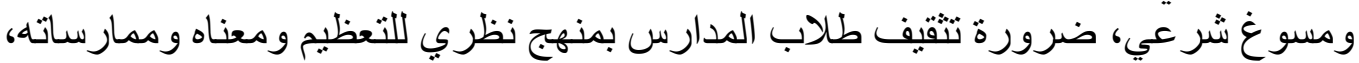

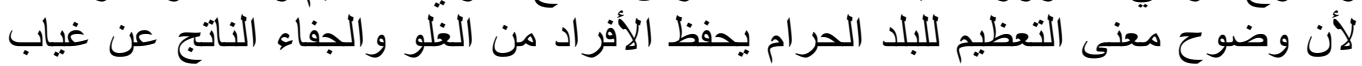
الجانب المعرفي الصحيح المنبثق من الكتاب و السنة. 


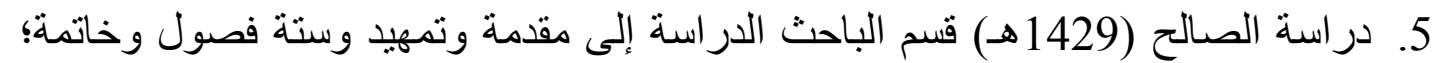

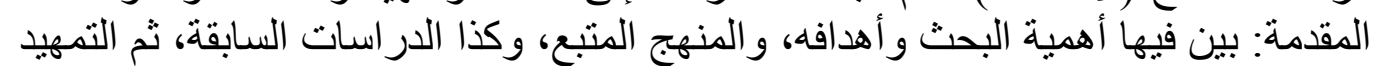

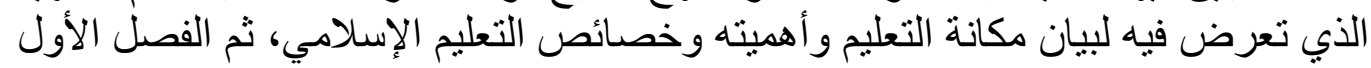

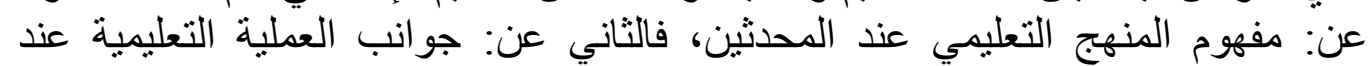

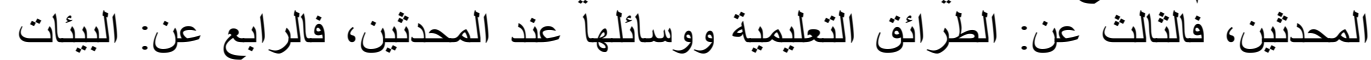
التعليمية عند المحدثين، فالخامس عن: التقويم التربوي عند التهدين التحدثين، فالسادس: الآثار

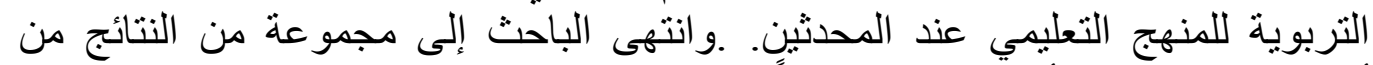

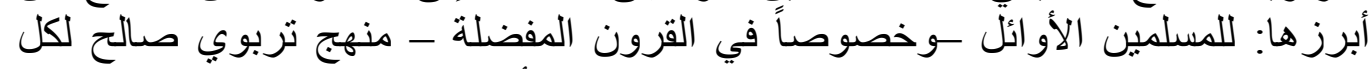

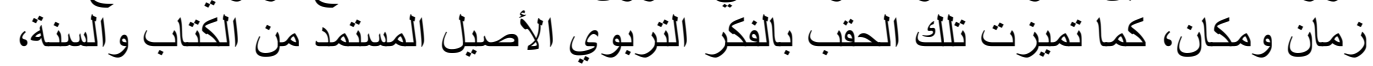

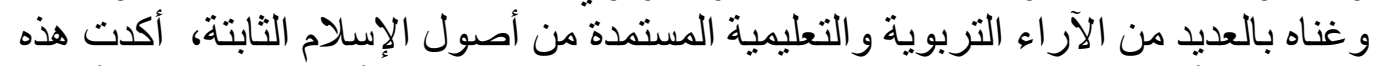

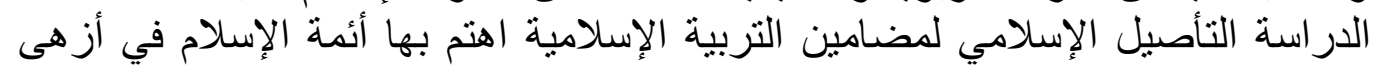

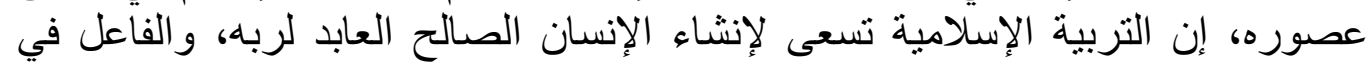
مجتمعه، ليتكون المجتمع المؤهن.

6. دراسة الصعيدي (2009): هدفت الكثف عن الأساليب النبوية التي استخدمها الرسول

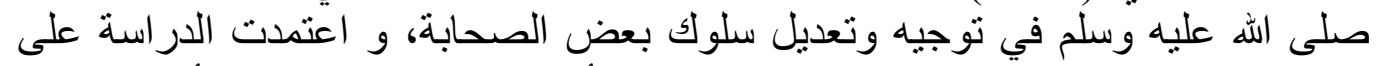

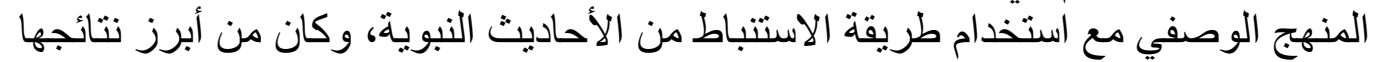

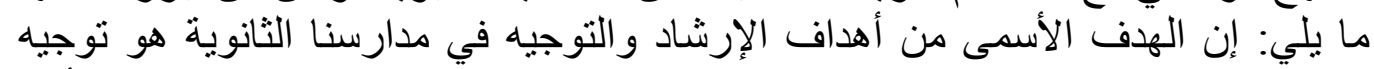

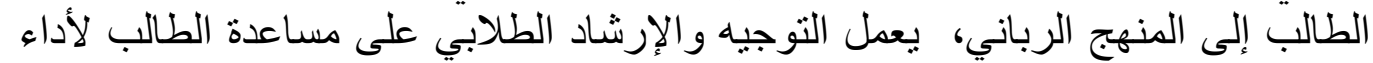

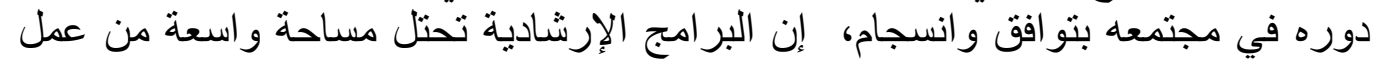

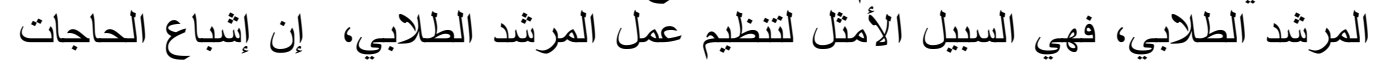

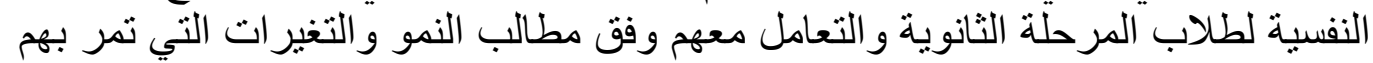

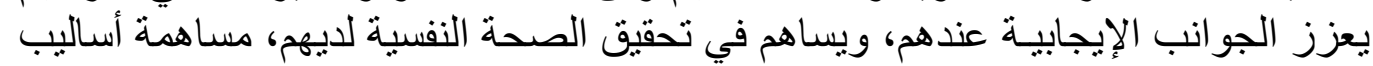
التربية النبوية في تنمية الجانب النفسي لشخصية النّية الطالب المسلم بالمرحلة الثانوية. 7. دراسة القرني (1430): هدفت الكثف عن أساليب علماء الحديث في التربية والتعليم في

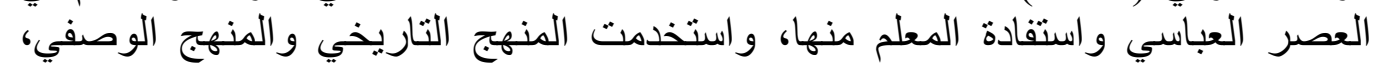

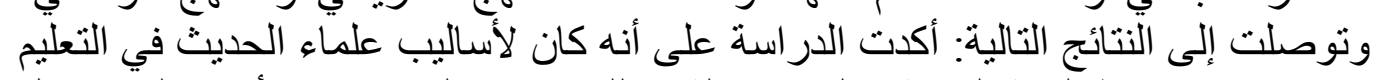

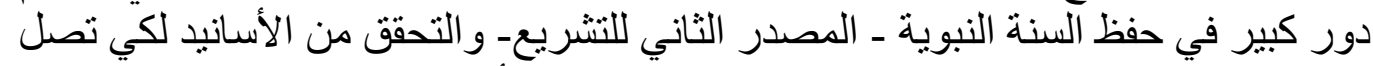

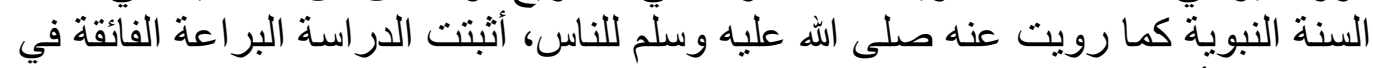

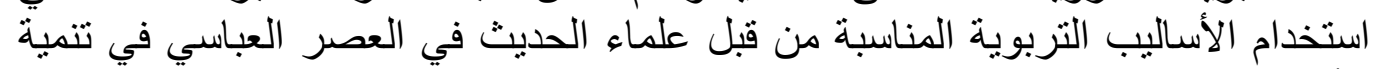

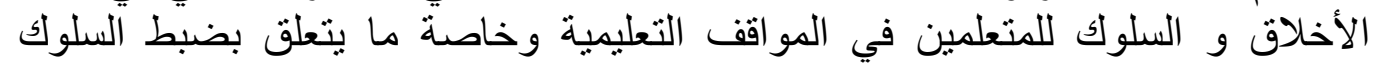

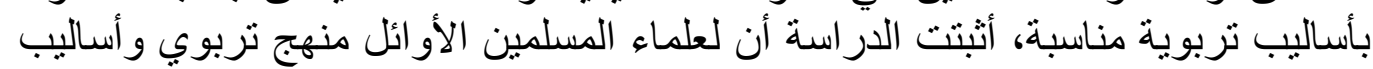

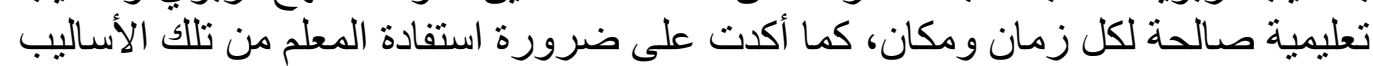
في المو اقف التعليمية وذلك للتنمية المعرفية و السلوكية المتميزة و المثمرة للأجيال. 


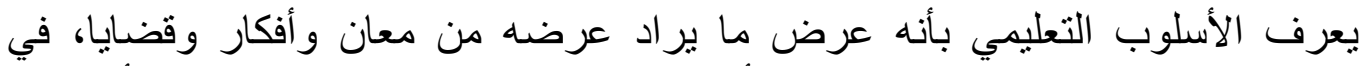
عبار ات وجمل مختارة لتناسب فكر المخاطبين و أحو الهم، وما يجب النه لكل مقام من المقال. (أبا بطين

1412هـ، 523

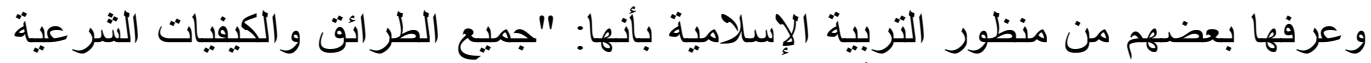

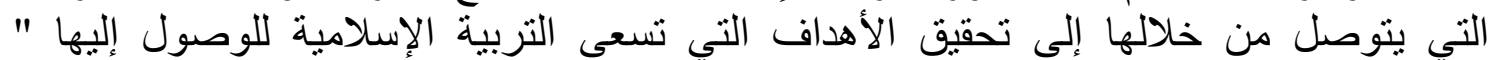

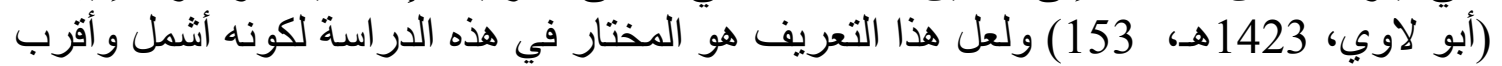
لجميع ما تهدف له التربية الإسلامية من أهداف و وغايات.

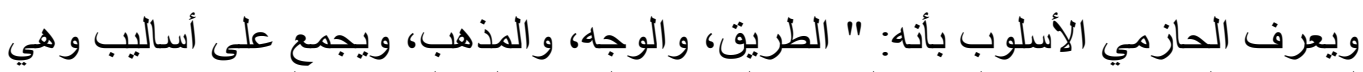

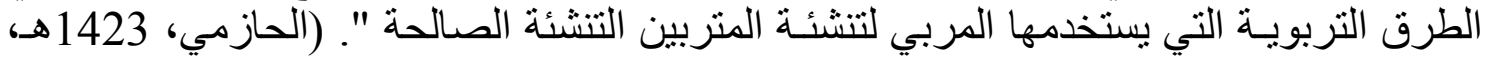

وقيل أساليب التربية و التعليم هي "وسيلة الاتصال التي يستخدمها المعلم لتوصيل المحتوى التوى التوبي إلى التلاميذ باستخدام أو كيفية تناول المعلم تلكالك الوسيلة أثناء قيامه بعملية التدريس". (الثمري، (86، 2003

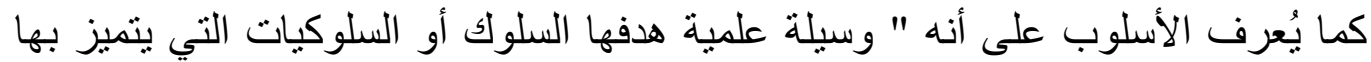

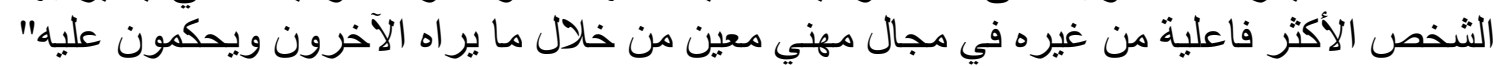

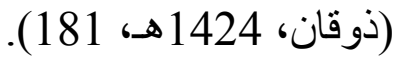

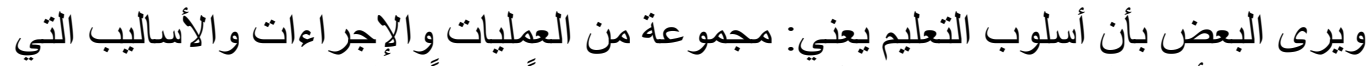

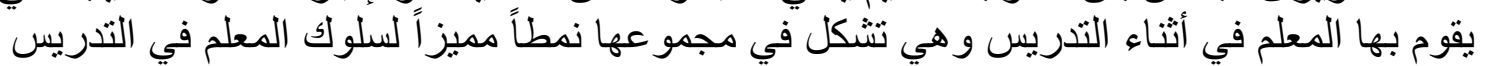

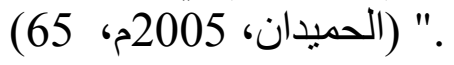

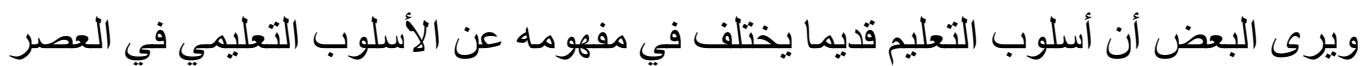

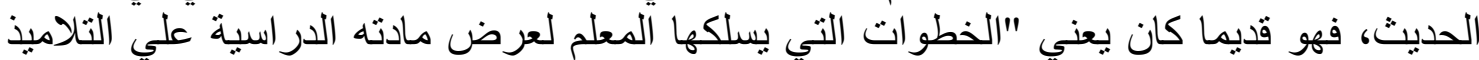

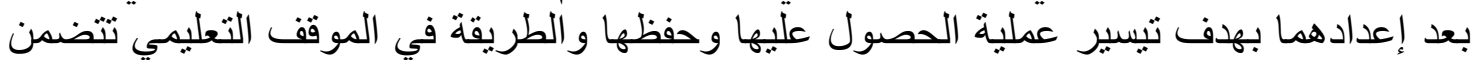

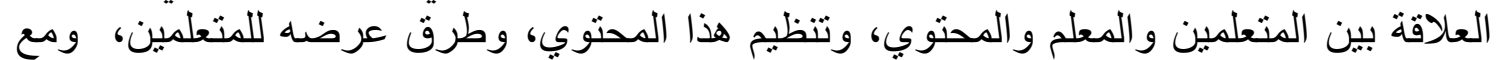

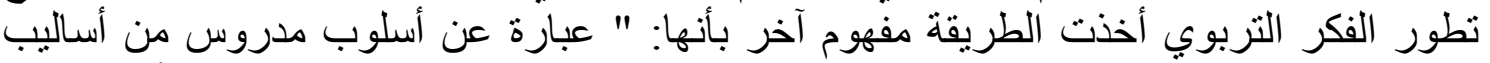

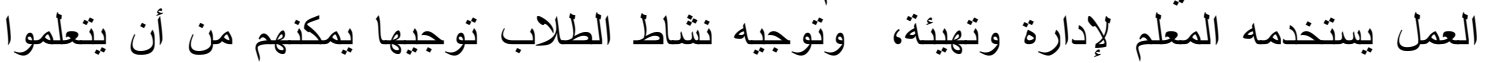

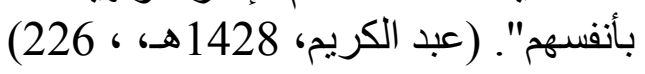

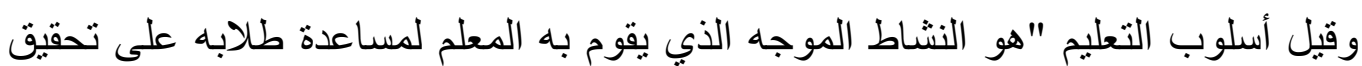

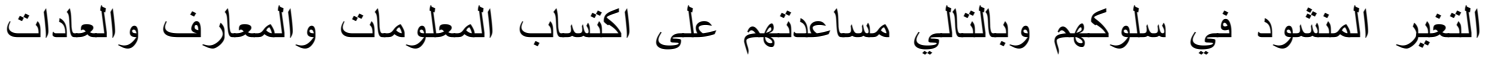

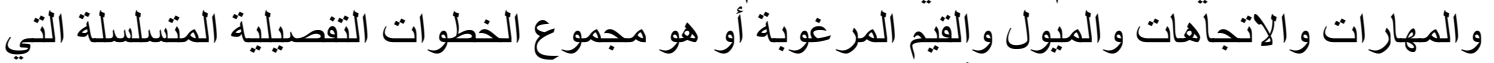

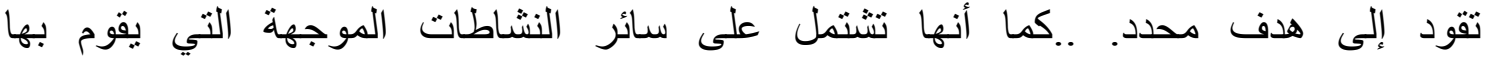
الطلبة".(الساموك، 2005، 149) "و الأساليب النبوية هي الطريق النبوي أو الطرق النبوية في النربية ". (حافظ، 1428هـ، 


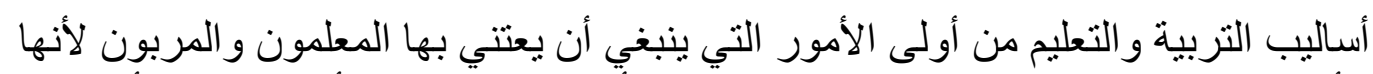

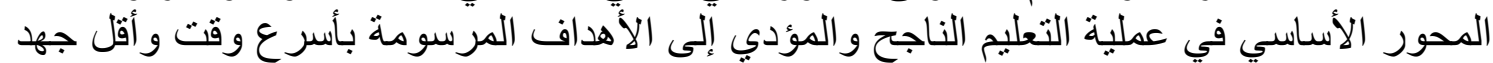

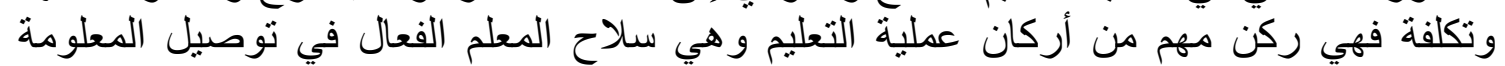
وتعديل السلّك و وهي الطريقة السهلة و اليسيرة للاب المربي في في تنمية شخصية التمنربي.

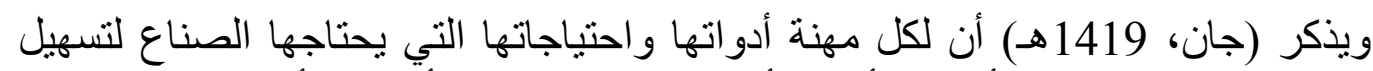

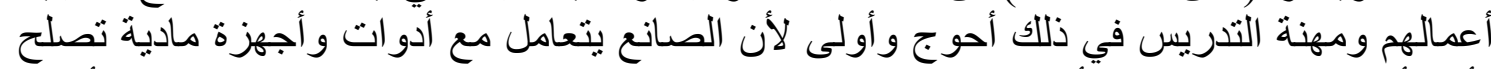

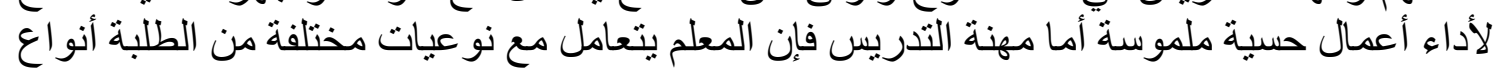

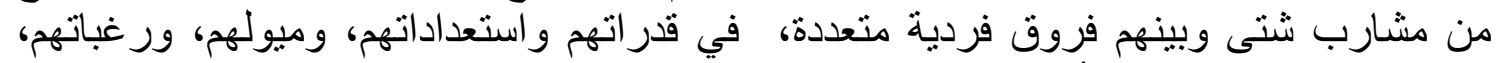

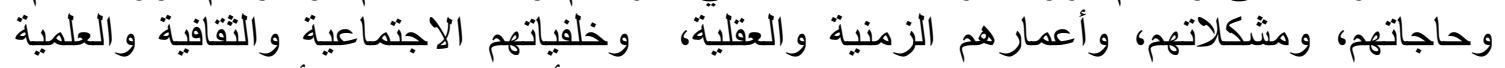

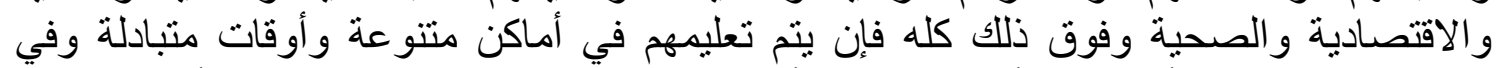

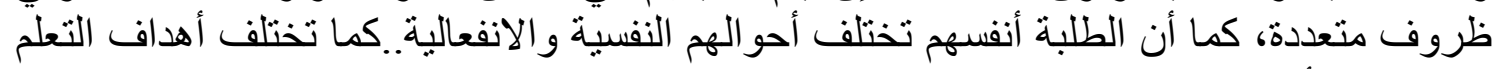

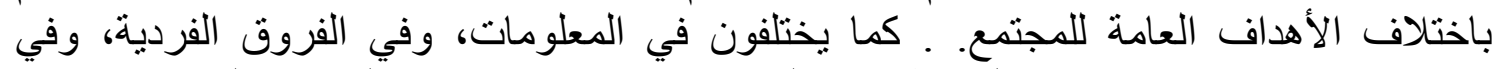

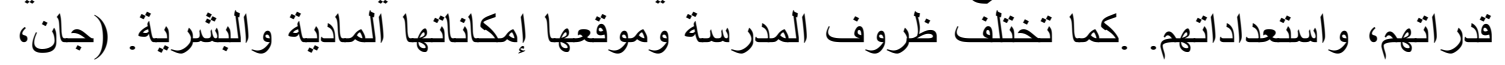

1419 هـ، 424)

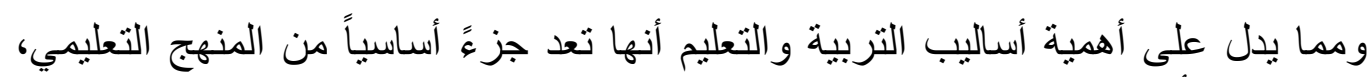

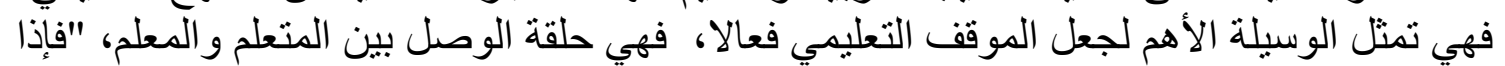

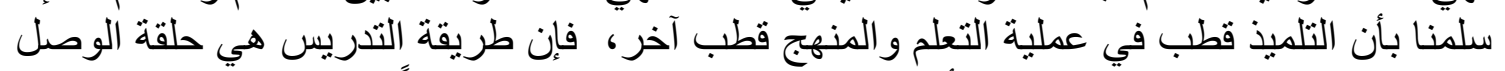

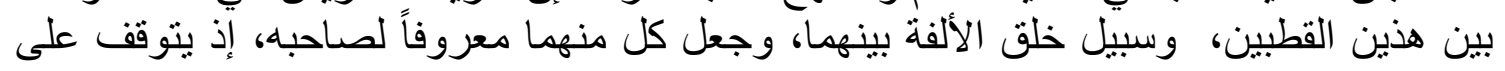

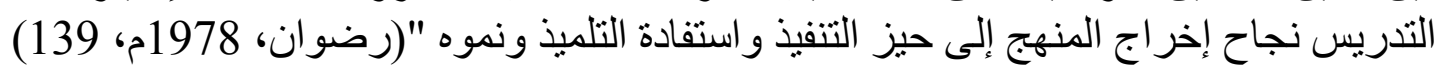

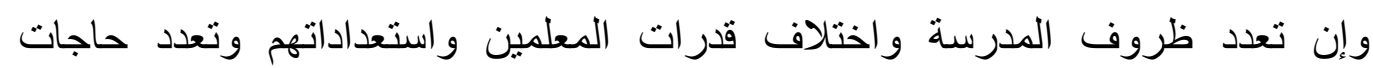

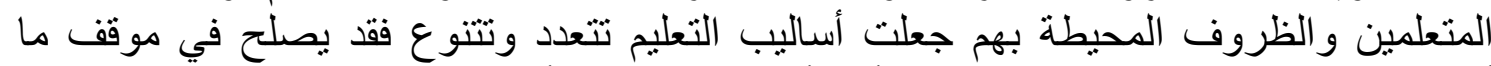

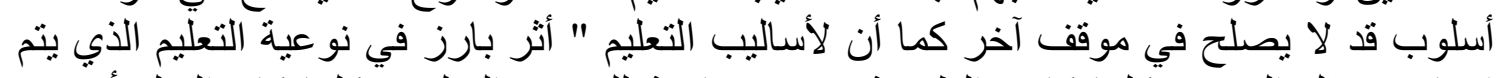

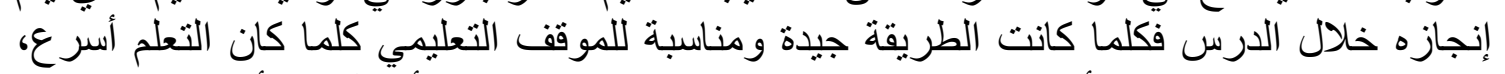

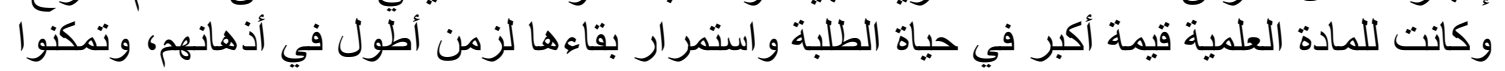

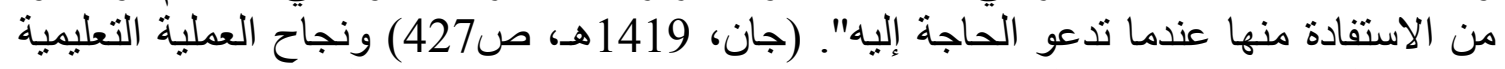

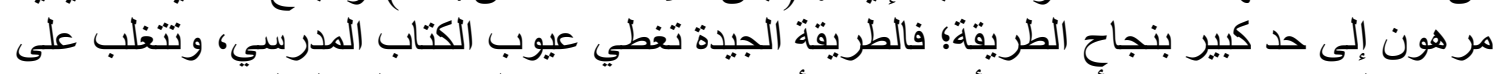

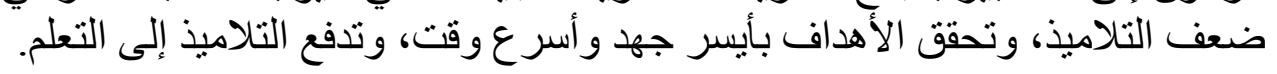

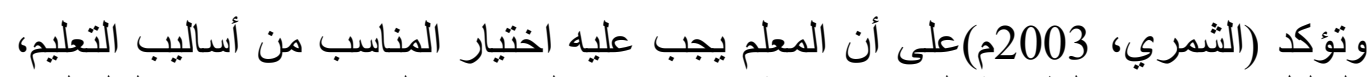

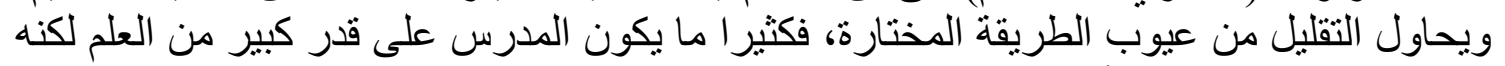

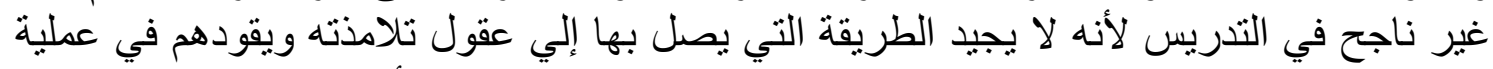

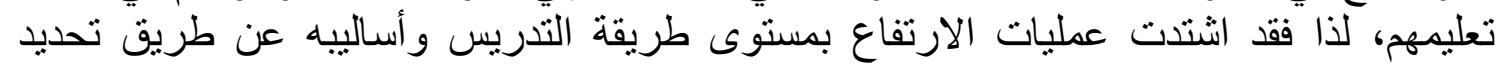

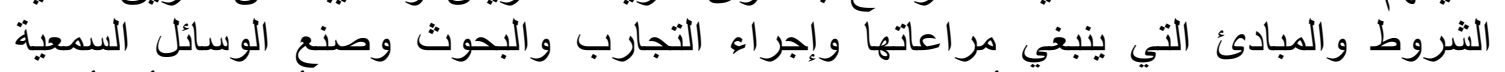

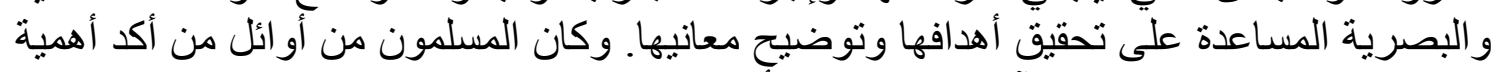

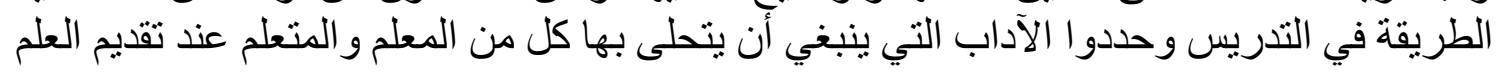

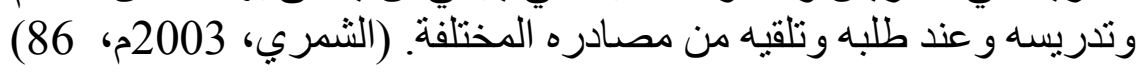


كما أن للأساليب التربوية أهمية كبيرة في العملية التربوية، يمكن إيضاحها فيما يلي:

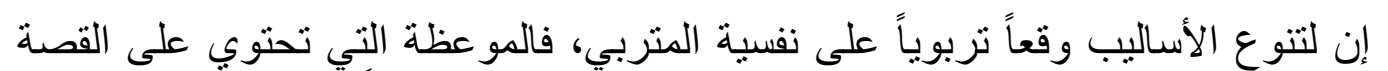

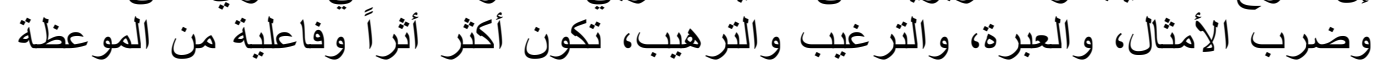
المجردة، أو الأسلوب الأحسادي.

تمكن المربي من اختيار ما يناسب و اقع الحال للمتربي، و الظروف المحيطة به.

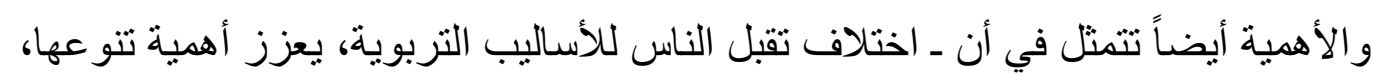

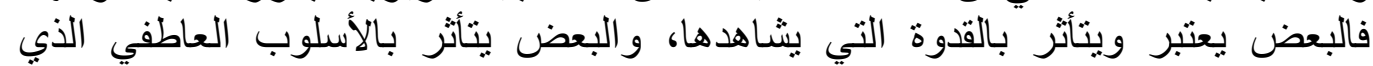

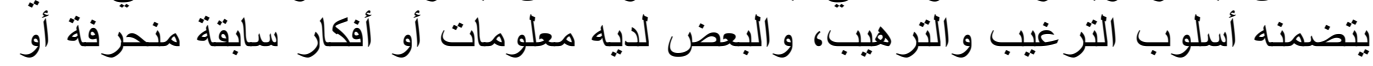

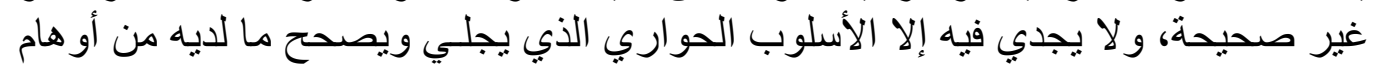

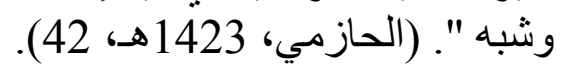

ويمكن مما سبق أن يستتتج عدة أمور تدل على أهمية أساليب التربية والتعليم ومنها

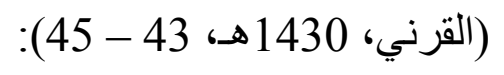

أن أساليب التربية والتعليم هي الوسيلة المثلى للوصول إلى الأهداف وتحقيق أفضل النتائج

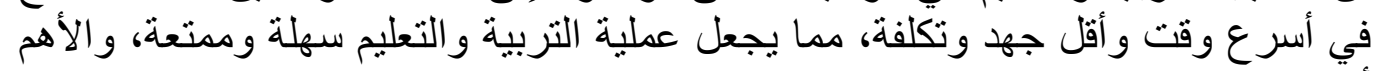
أنها تكون مثرة ونر وبناءه.

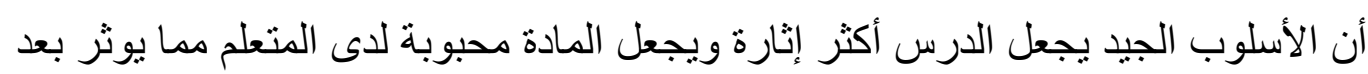

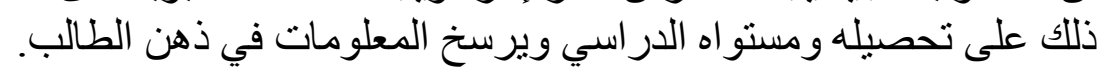
أن أساليب التربية و التعليم تساعد على التوازن في بناء شخصية الفرد والاستغلال الأمثل

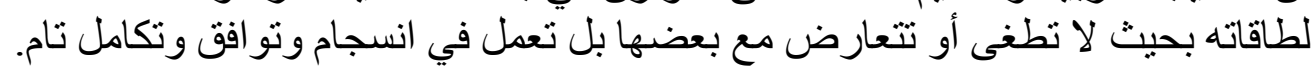

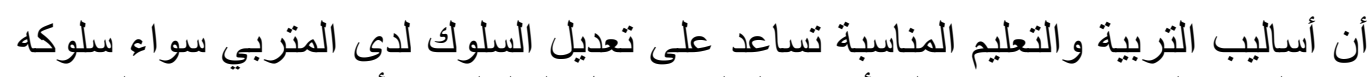

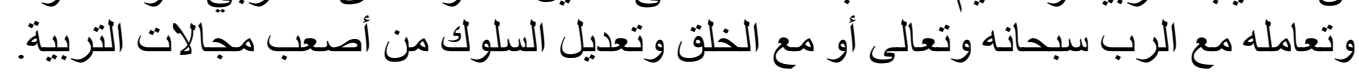

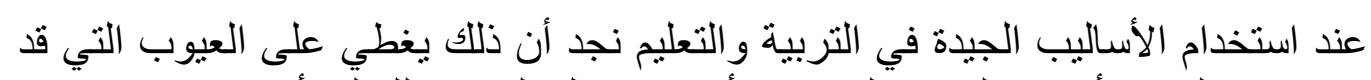

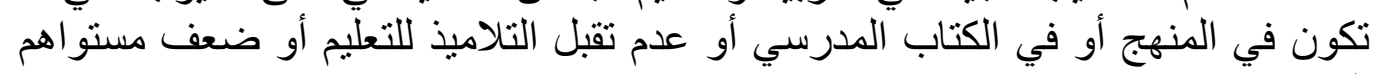
الدر اسني.

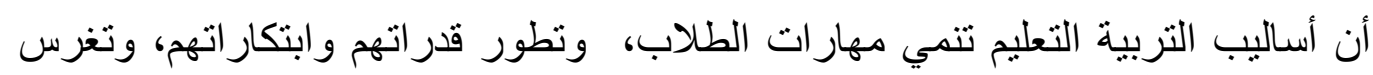

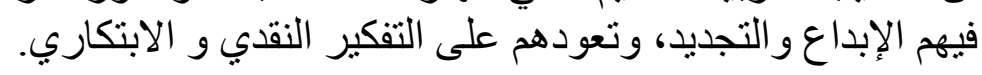

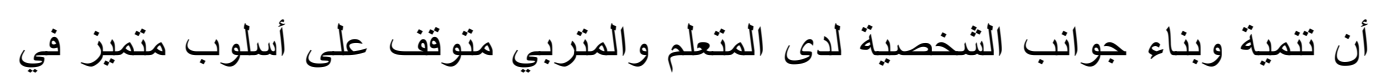

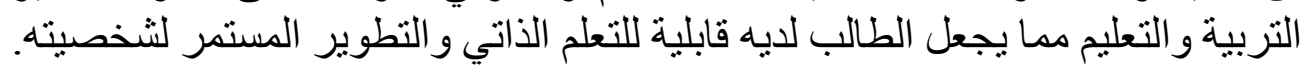
أن صعوبة القيام بعملية التربية لاختلاف الأذو اق والاتجاهات و الظروف يجعل من الأهمية

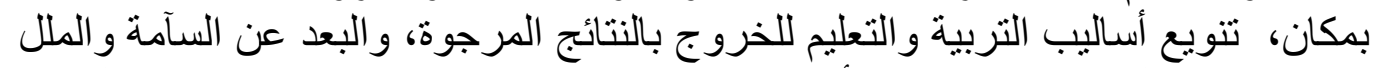

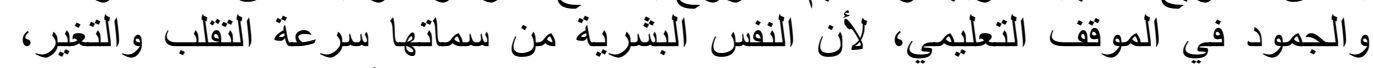

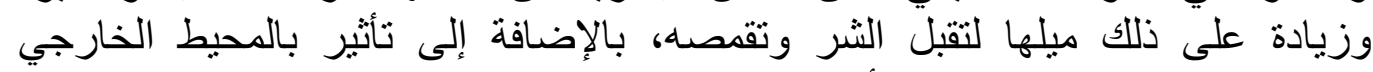

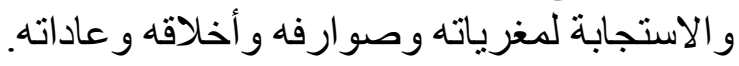


الوسائل التعليمية: وهي كل أنواع الوسائط التي تعين المعلم على توصيل المعلومات

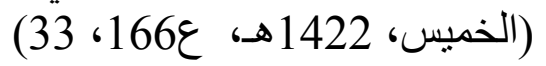

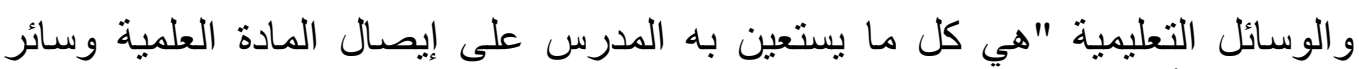
المعارف و القيم إلى أذهان الطلاب وتوضيحها "'"(طويلة، 1418هـ، 161 1لئل

ولعل التعريف الثاني هو الأشمل لكون الأول اقتصر على الجانب المعرفي وتوصيل المعلومة فقط للطالب بينما الآخر شمل سائر المعارف و القير.

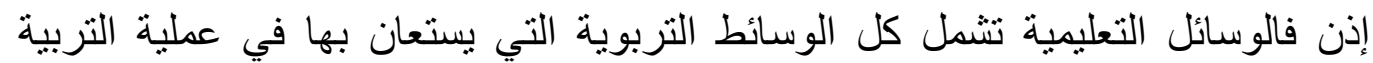

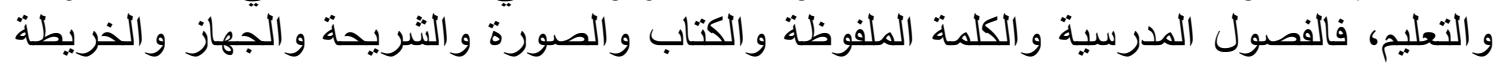
و المجسم. .و غير ها و هي كلها وسائل هامة لتوجيه و إنتاج التربية و التعليم الجيد للنانئئة.

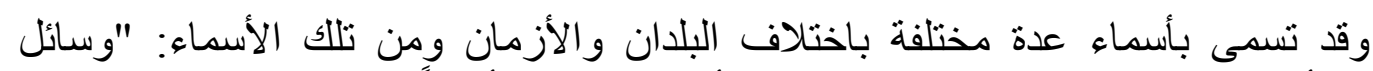

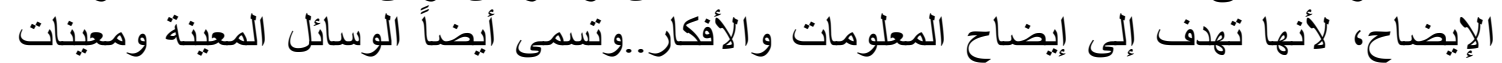

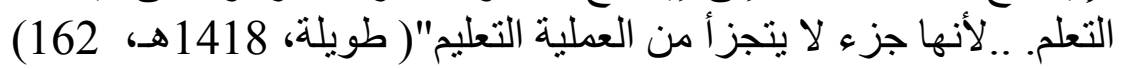
2. 2. 2 أهية الوسائل التعليمية:

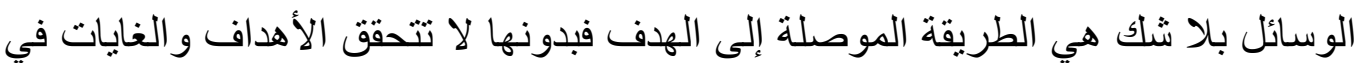

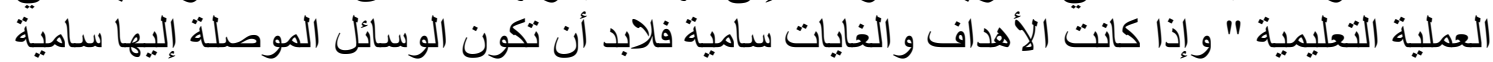

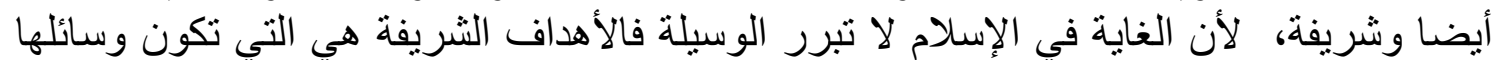

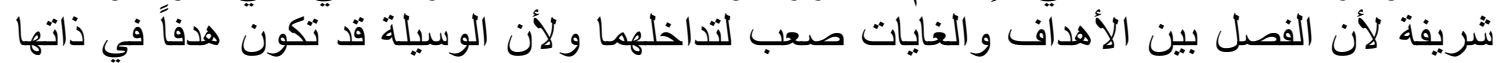

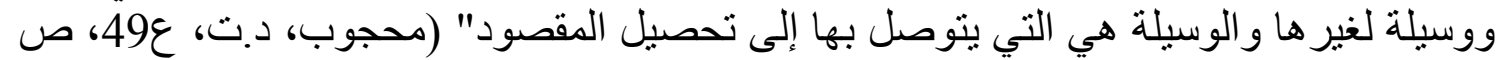

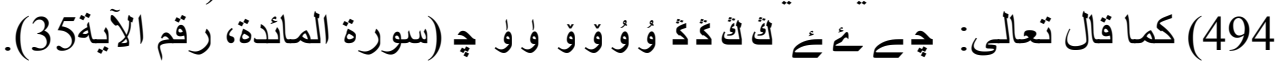

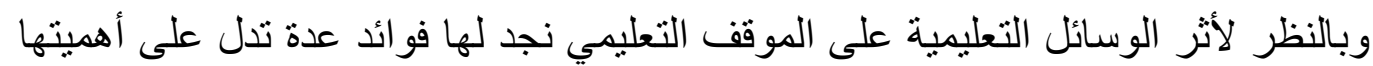

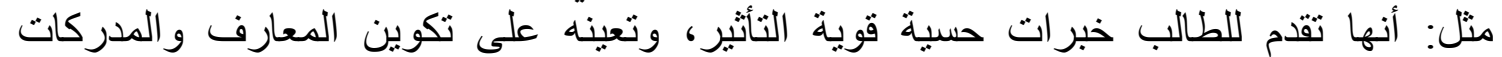

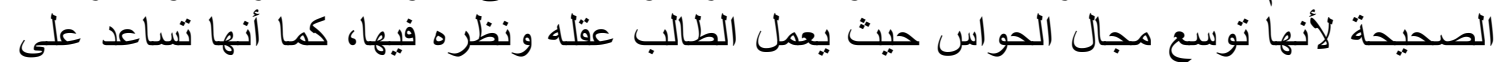

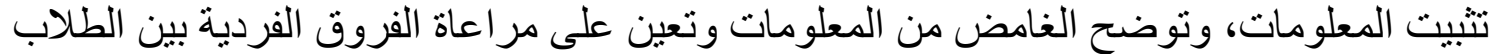
وتتمي في الطالب إتباع الأسلوب الغطان العلمي في التفكير. (طويلة، ويمكن مما سبق أن يستنتج بعض الفروق بين أساليب التربية والتعليم ووسائلها ومنها

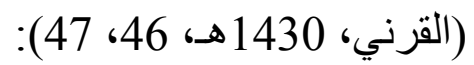

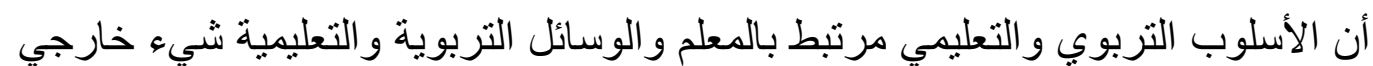

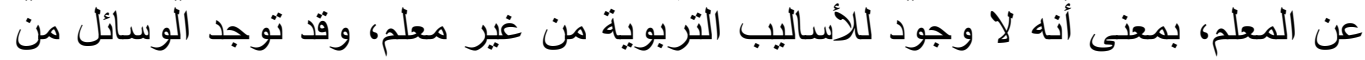

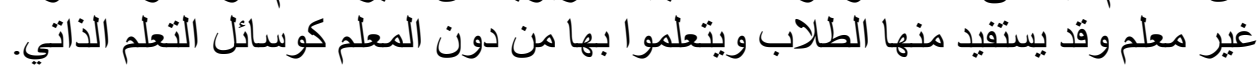

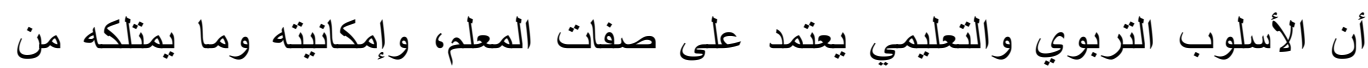

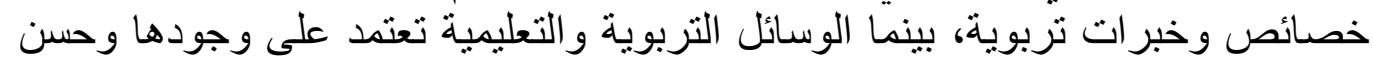
اختبار ها، ومن ثم حسن استخدامها، و هنا قد يكون للمعلم دوره و والحاجة إليه. 
أن الأسلوب التربوي والتعليمي شيء معنوي وغير محسوس بينما الوسائل التربوية و التعليمية هي أثياء مادية ومحسوسة ولتئية وملموسة فقد تكون أدو ات أو أجهزة سمعية وبصرية

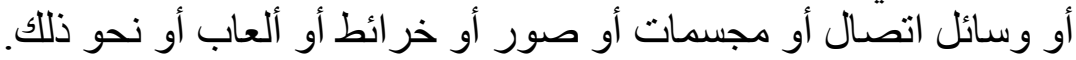

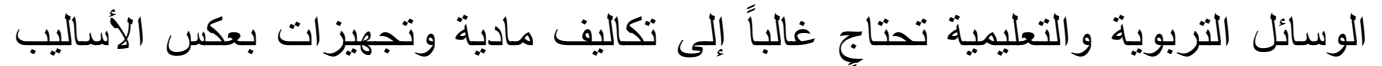

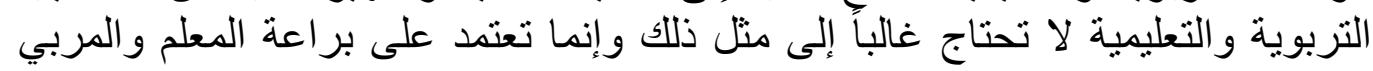
وخبر اته وقدر اته.

الوسائل قد بحتاج فيها المعلم إلى مساعدة أشخاص آخرين بساعدونه فيها، مثل: مُحضّر

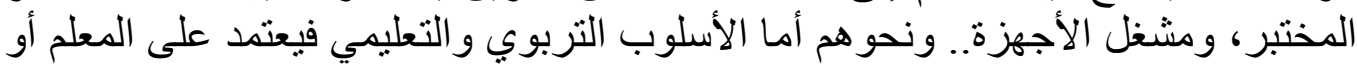
المربي بشكل مباشر.

أن الوسائل التربوية والتعليمية تزيد من فعالية الطالب ونشاطه داخل الحجرة التعليمية مما التها

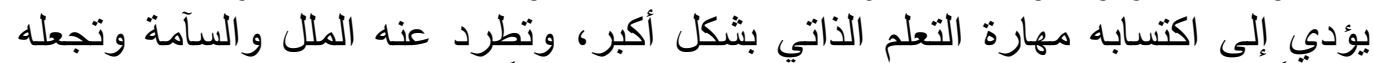

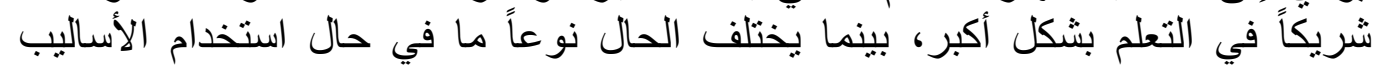
التربوية والتعليمية، حيث تقل مشاركته مما يتطلب مزيد من الجهد من قبل المعلم. المحور الثاني: بعض أساليب التربية والتعليم في السنة التبوية وتطبيقاتها التربوية:

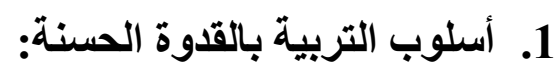

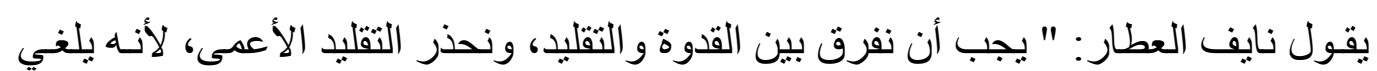

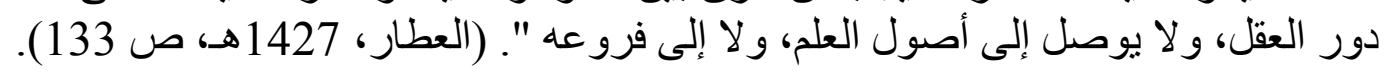

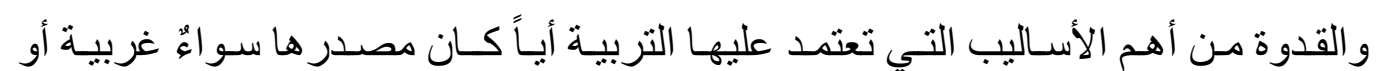

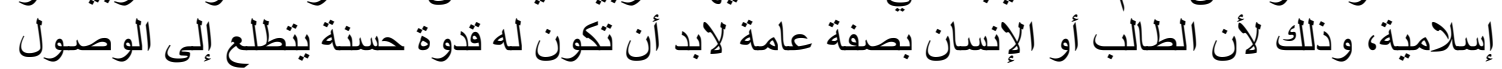

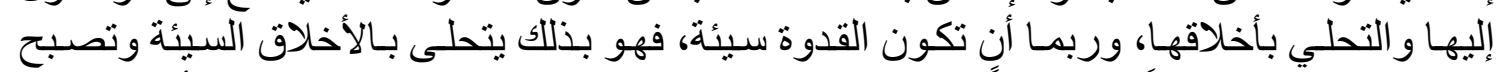

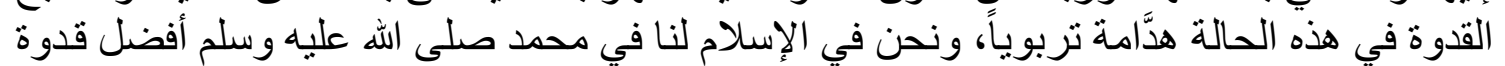

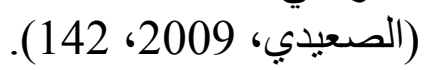

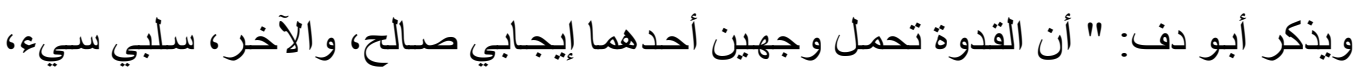

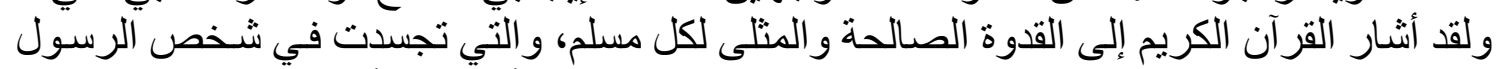

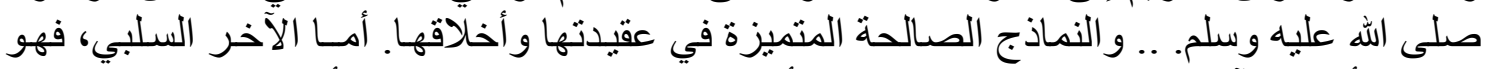

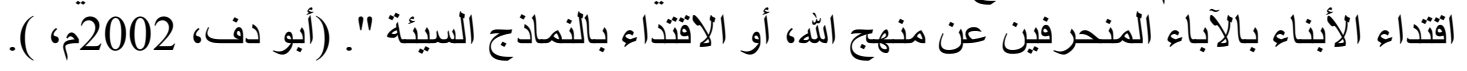
ويقول العطار: " ويكون نأثير القدوة في المقتدي بطريق عفوي غير مقصدود، أو بطريق

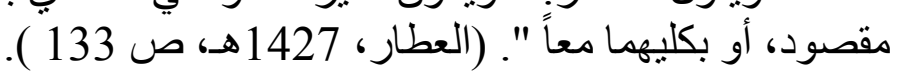

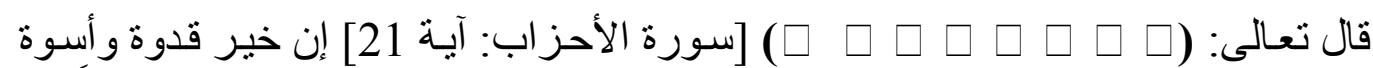

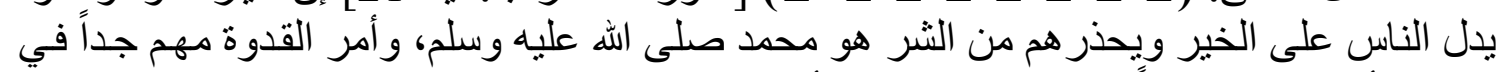

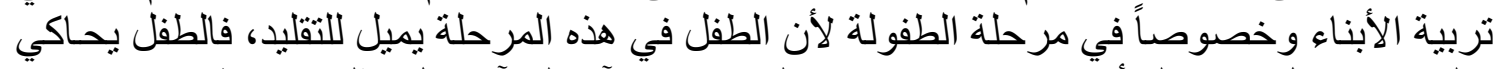

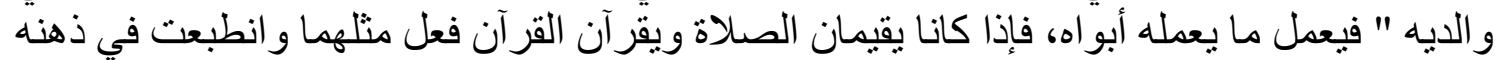

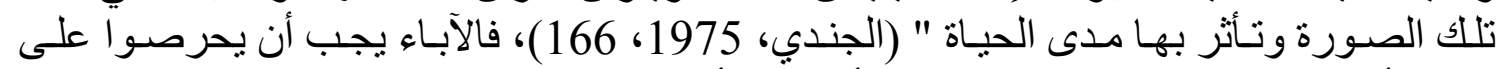

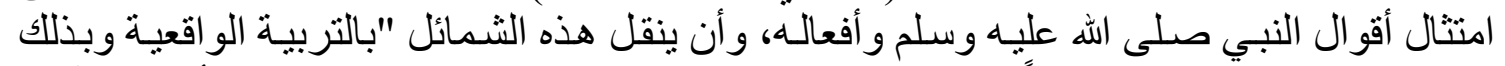

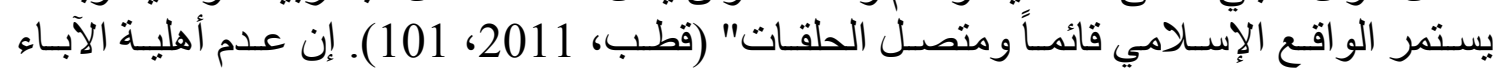

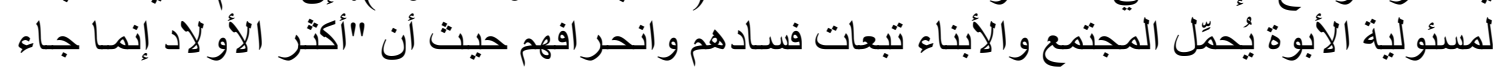

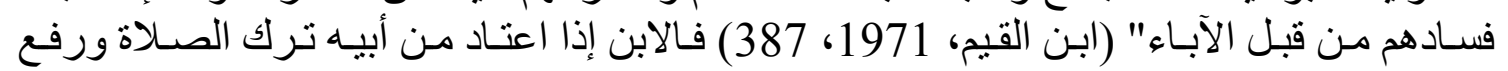




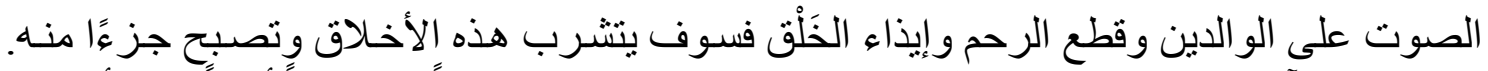

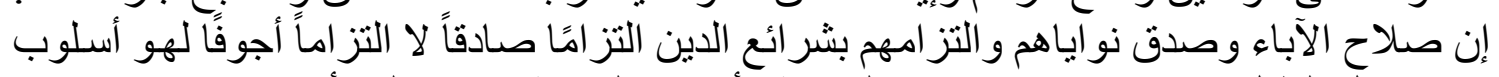

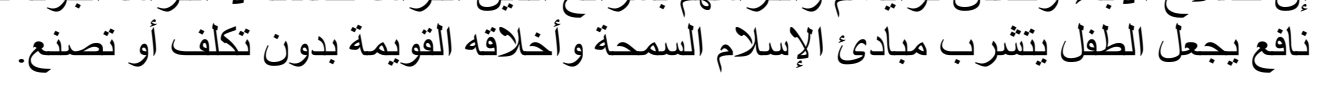

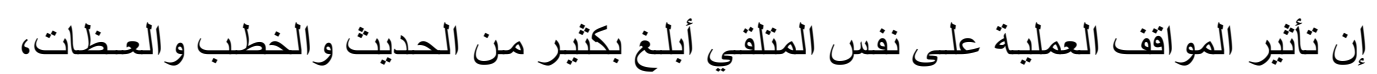

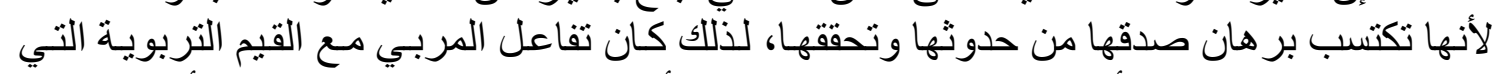

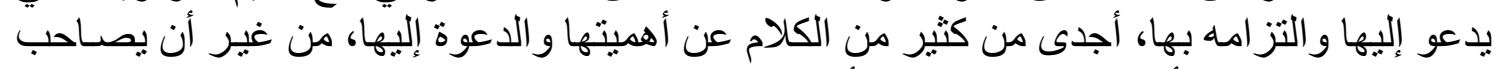

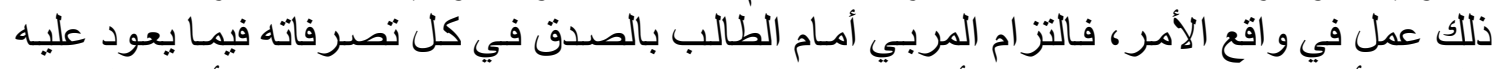

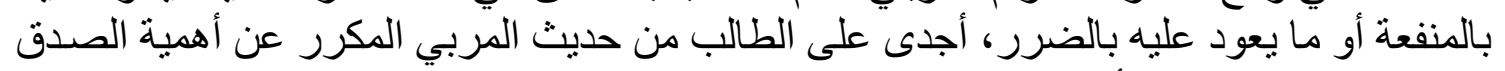

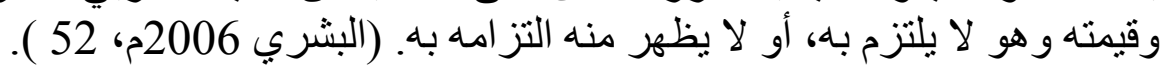

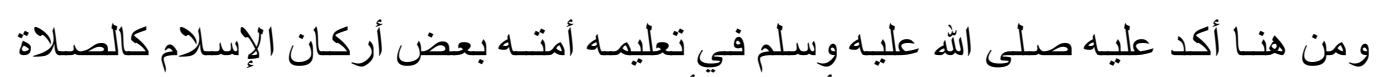

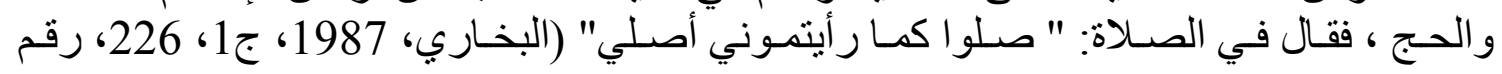

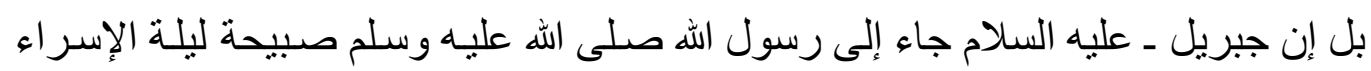

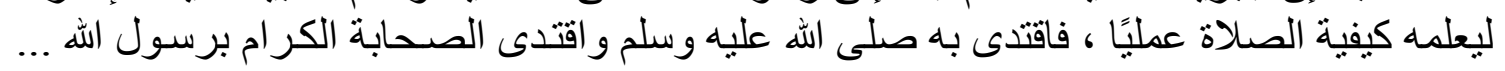

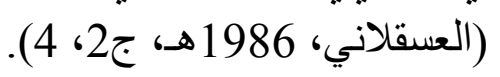

عُمقُ التأثير في النفس البشرية، وسـر عة استجابتها للأمور العملية أكثر من استجابتها

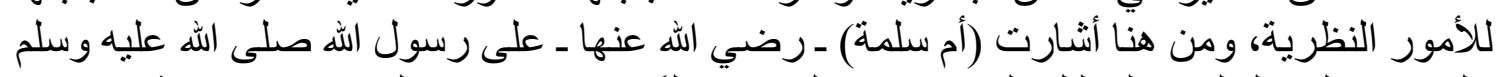

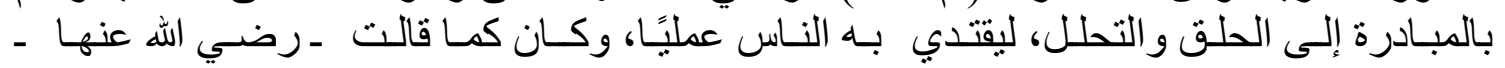

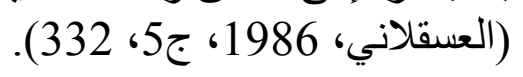

وكان بعض الصحابة ـ رضوان الله عليهم ـ يُصلي بالناس وهو لا بريد إلا أن بعلمهم صلاة

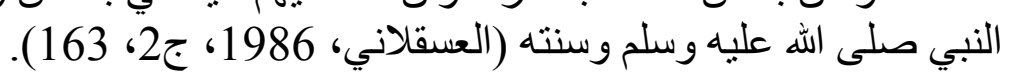

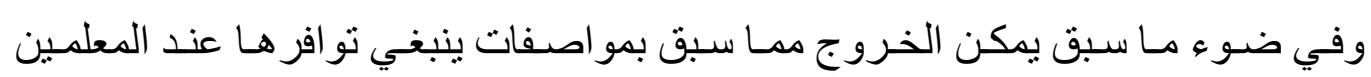
لتتكامل فيهم مواصفات القدوة الحسنة و القبول عند الطلاب (معلم، 1429 هـ، 150): ومن الصفات المهمة التي ينبخي أن لا يغفلها المعلم القدوة:

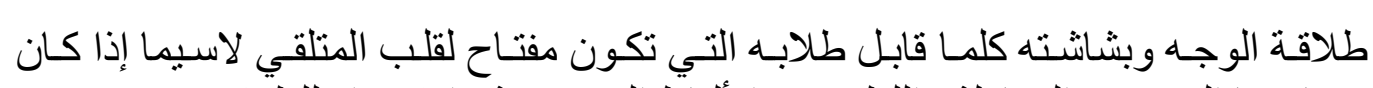

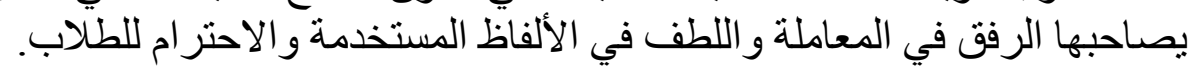

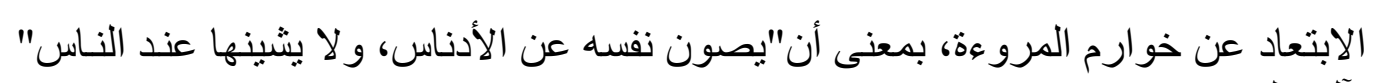

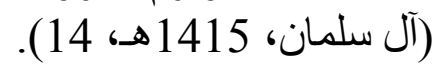
أن يطابق فعله قوله. 2. أسلوب التربية بالقصة:

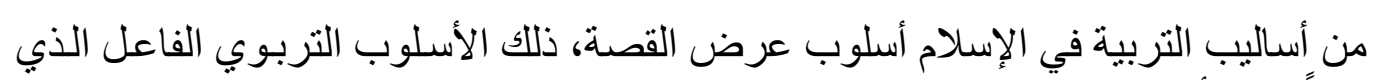

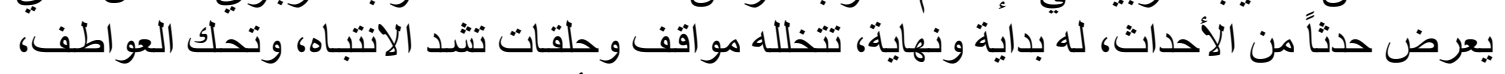

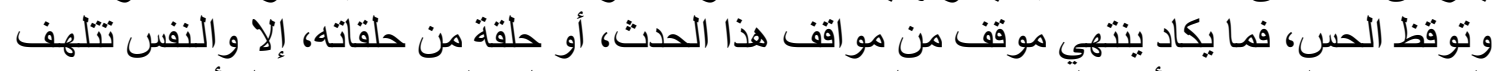

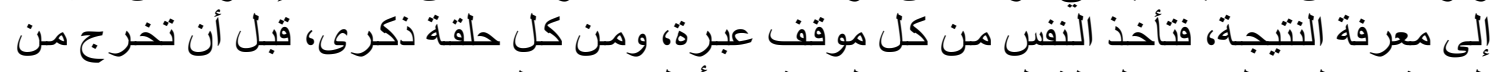

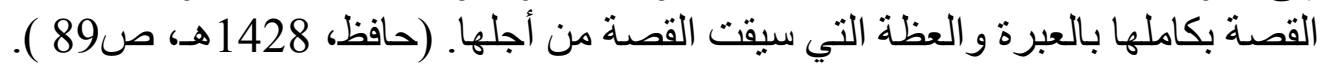




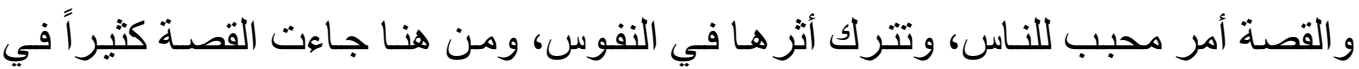

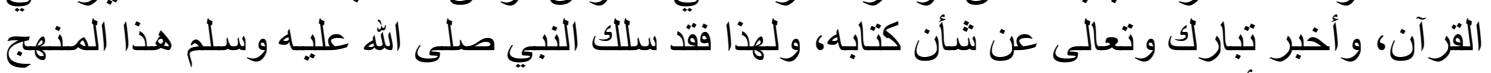

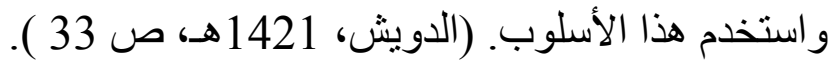
ولقد أكد القرآن وحث على قصِّ القصص لأثر ها الإيجابي والفعال على الفكر فقال تعالى:

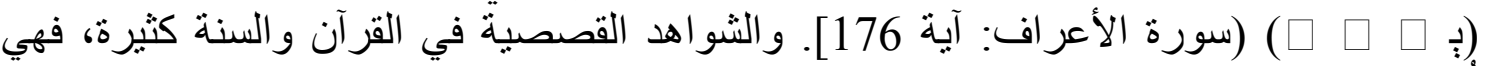

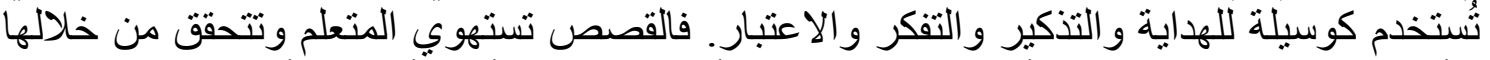

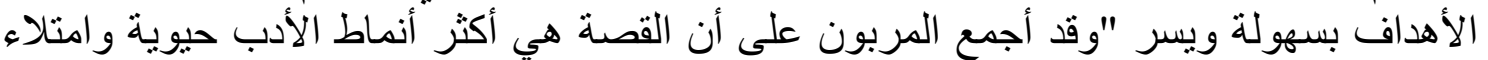

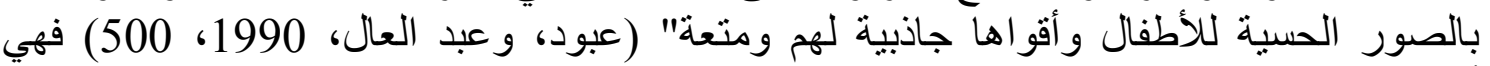
أسلوب محبب للطفل، "حيث تعمل على شد انتباهه ويقظة إحساسه" (طه، و آخرون، 1992، 48). إن القصة أمر محبب للناس، وثترك أثرها في النفوس، ومن هنا جاءت القصة كثنير اً في

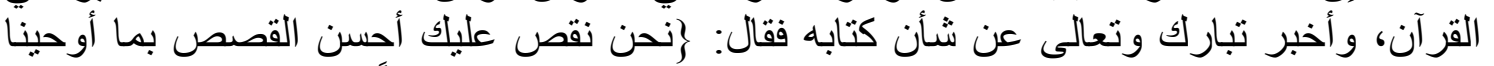

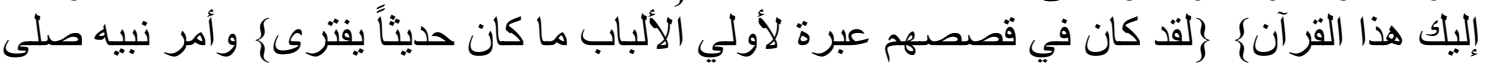
الله عليه وسلم بذلك فقال: (و أقصص القصص لعلهم يتفكرونج ولهذا فقد سلك النبي صلى الله عليه وسلم هذا المنهج و استخدم هذا الأسلوب.

ولذلك نجد أن القصة لها حيز كبير من المنهج الرباني في النصوص القر آنية وكذلك في

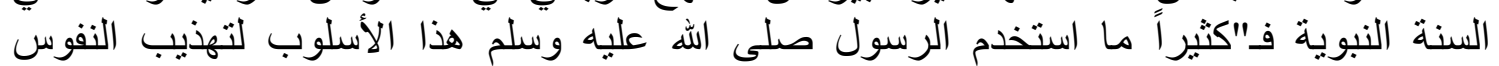

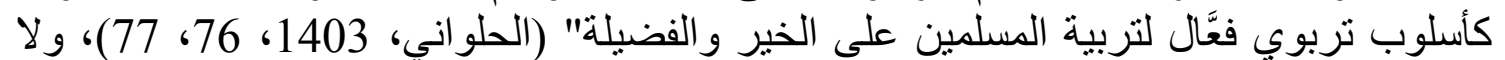
شك أن استخدام المنهج الرباني الكامل لهذا لتربة الأسلوب في تنشئة المسلم دلالة على على أهمية هذا

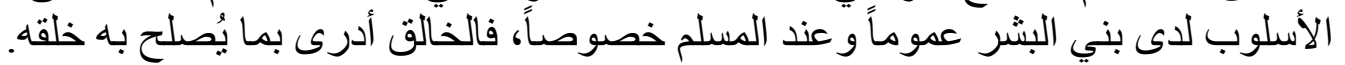

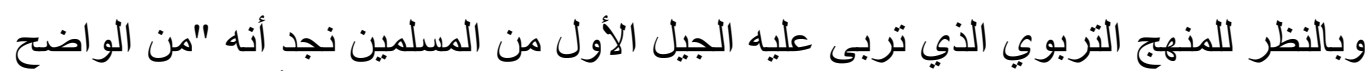

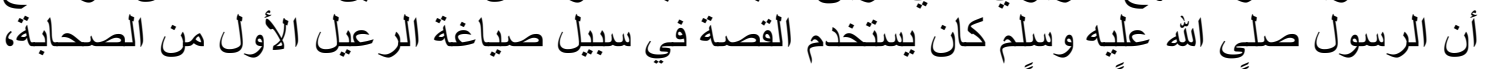

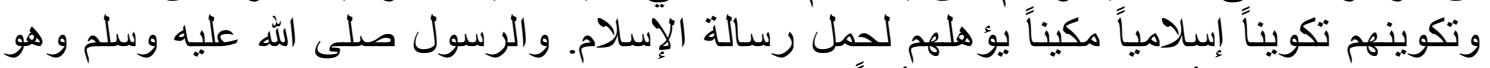

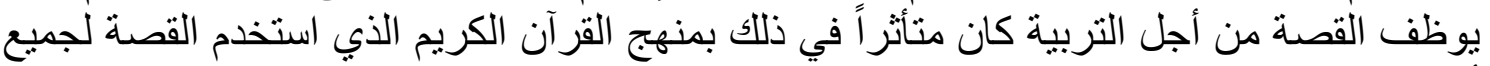

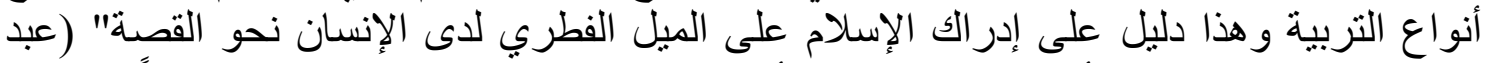

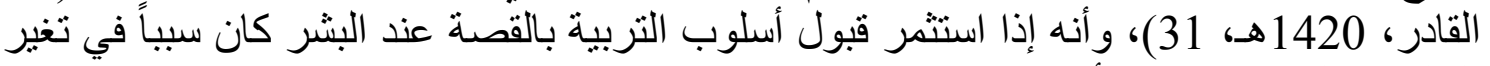
السلوك و القناعات لدى الأفر اد.

وتكمن أهمية القصة في كونها جزء من العملية التعليمية التي كانت في عهده صلى الله عليه

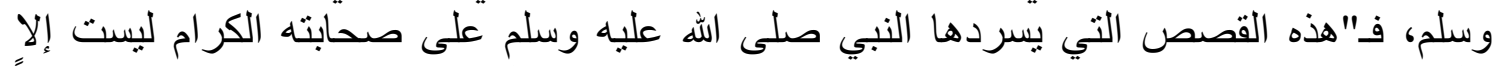

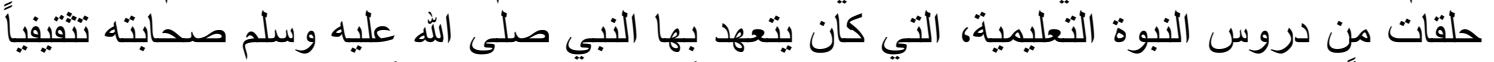

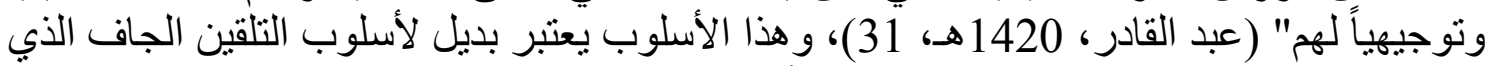
يعتمد على نقل المعارف كمعاني مجردة من الأحاسيس. و القصة أسلوب ناجح في التربية، و لا بستطيع المُربي أن بستغني عنها لأهميتها، فهي تُعمِل

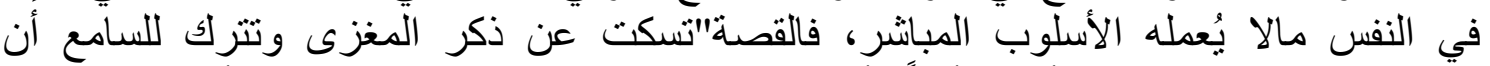

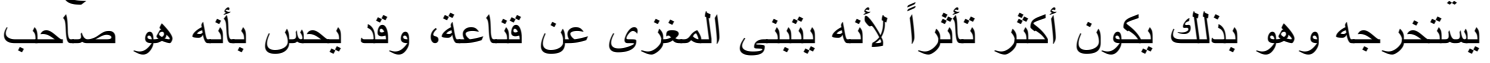

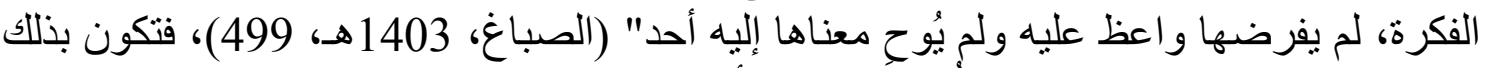

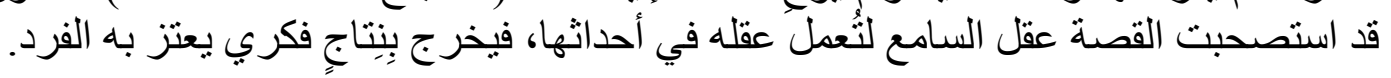
و الأسلوب القصصي يُحرّّك مر اكز التأثير في النفس من استثارة عاطفية وجدانية، و وإثباع

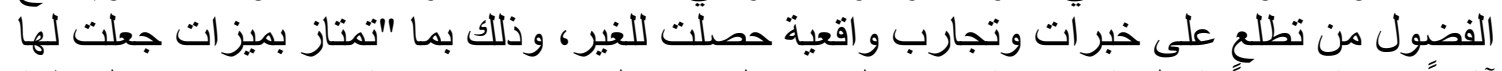

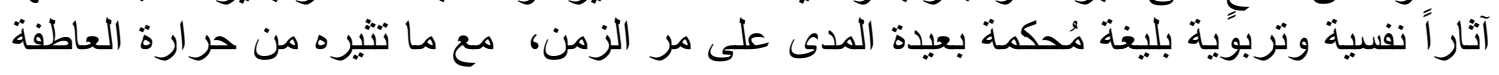


و ون حيوية وحركية في النفس، تدفع الإنسان إلى تغيير سلوكه وتجديد عزيمته بحسب مقتضى القصة وتوجيهها وخاتمتها و العبرة منها" (النحلاوي،

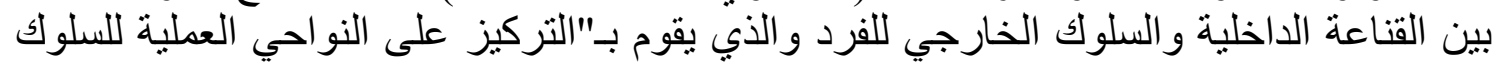

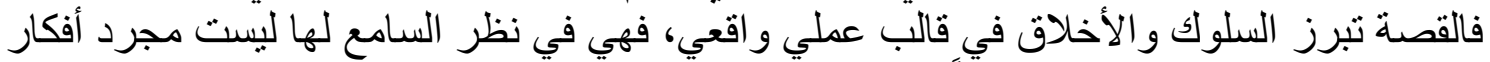

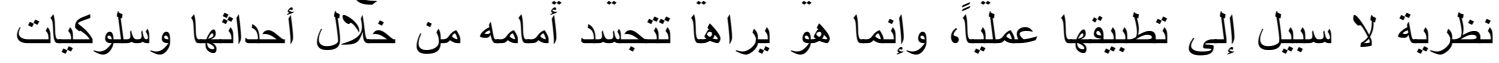

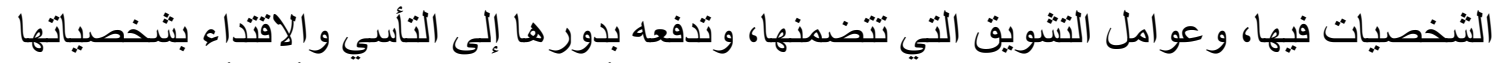
فيما هو خير" (السقاف، 1428هـ، 645)، و هذا ما يمكن أن يفسر به طريقة تأثير أسلوب التهبه التربية بالقصة على الفرد.

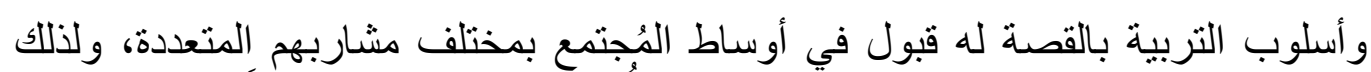

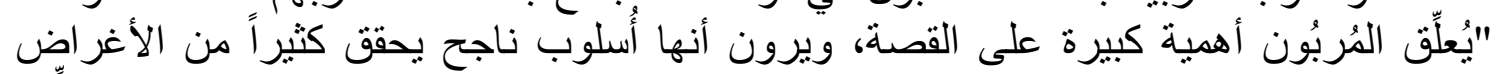

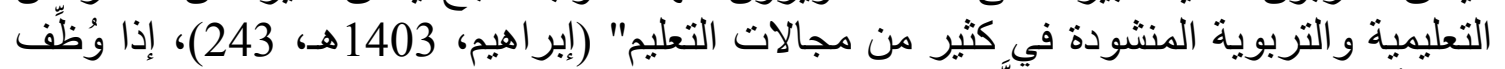
هذا الأسلوب بشكل صحيح ومُنظّلَّ.

وقد سن الله تعالى هذا الأسلوب في تعليمه لنبيه صلى الله عليه وسلم. قال تعالى: (وكلا"

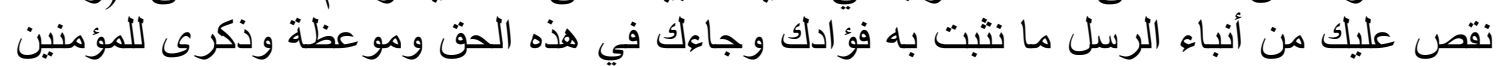
(سورة هود، الآية: 120)

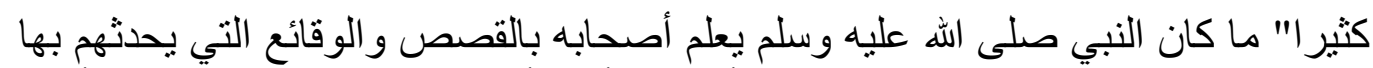

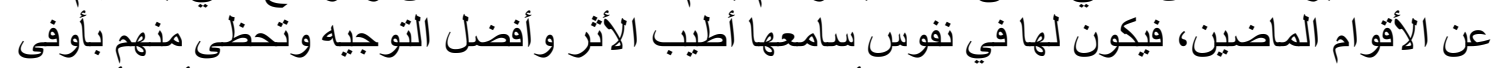

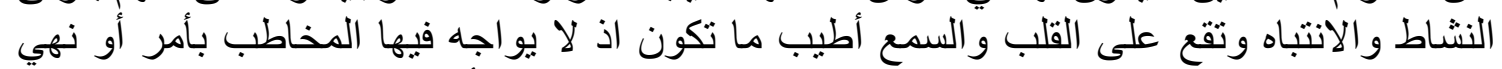

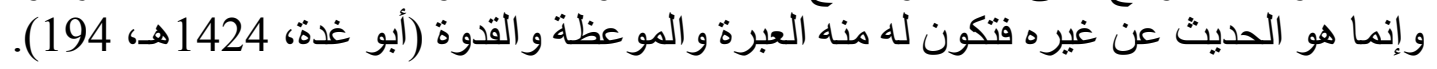

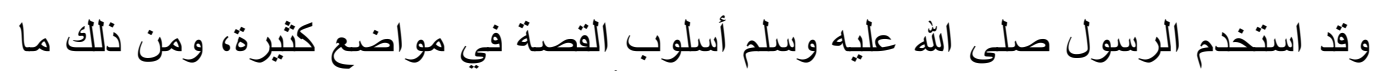

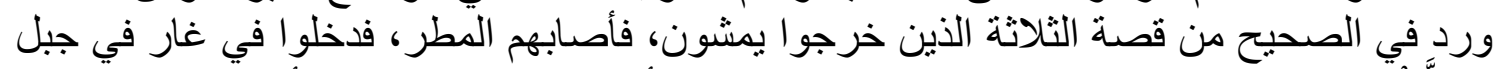

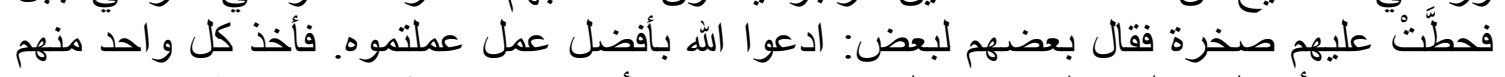

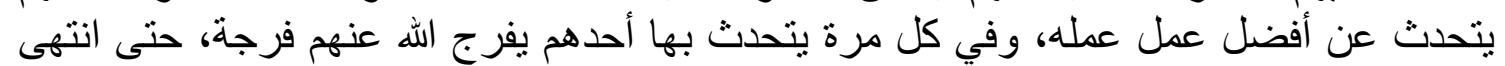

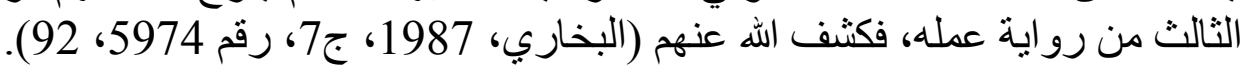

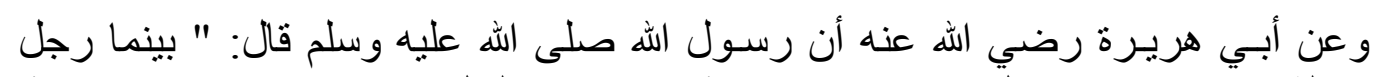

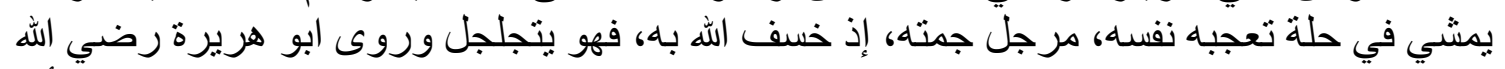

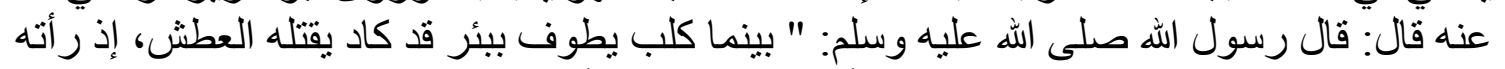

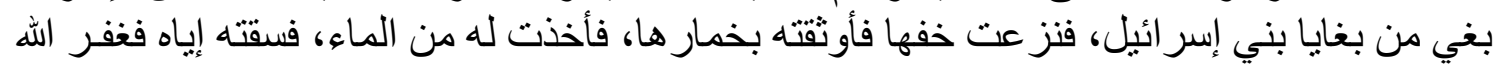

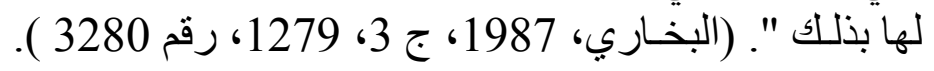

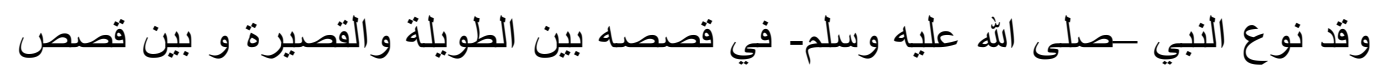

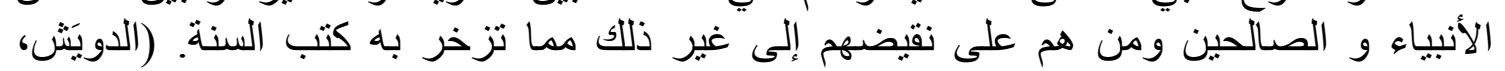

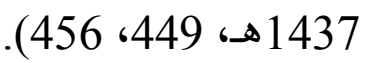

وفي ضوء ما سبق ينبغي للمُربي أن يأخذ باعتباره عند استخدام أسلوب التربية بالقصة

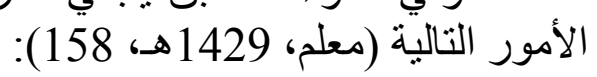

اختيار القصة المناسبة للهدف الذي وضعه المعلم لتحقيقه في اللقاء.

إعـادة صياغة القصـة - إذا احتـاج الأمـر - بألفاظ و اضـحة مستخدمة لدى طـلاب المرحلـة التعليمية الذين يتعامل معهم. 
الوقوف على أحداث القصة و عبر ها المستنبطة وكيفية الاستفادة منها وتطبيق عبر هـا في

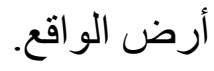

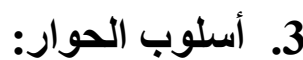

الحوار هو عبارة عن مناظرة بين طرفين أو شخصين بلوغا إلى الحق أو جلاء للصواب "

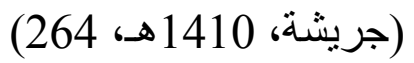

وعرفه الأهدل (1421هـ، 53) بقوله: " هو نوع من من الحديث يتم بين شخصيتين على الأقل

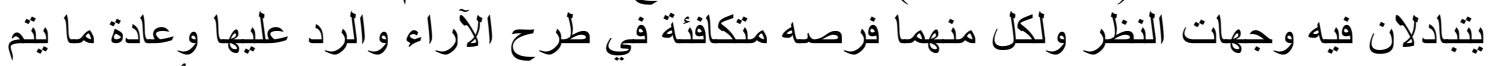

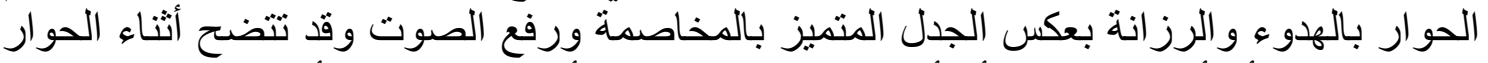

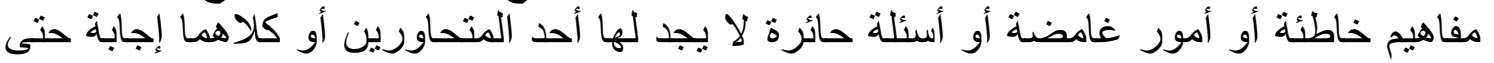

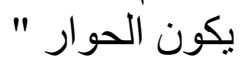

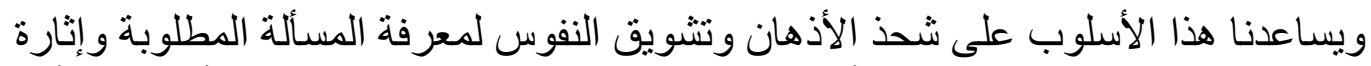

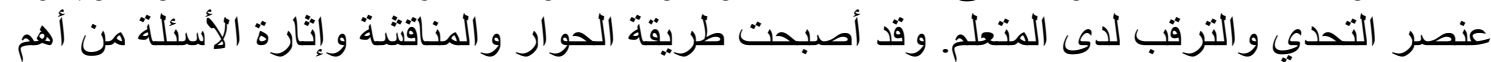

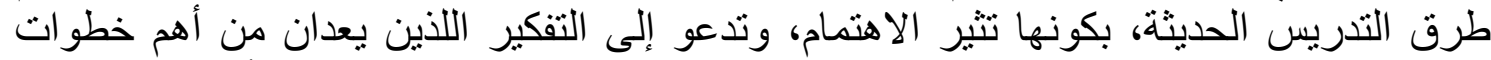

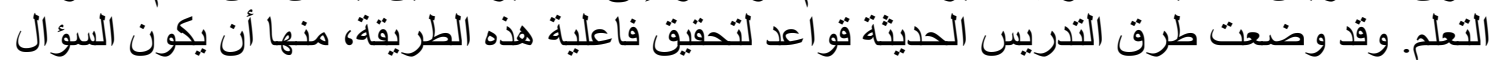

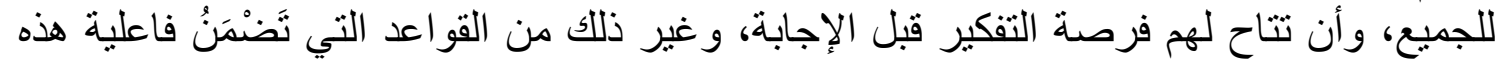

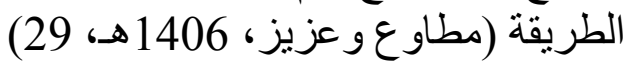

وكانت هذه الطريقة هي طريقة القرآن الكريم في استئصسال جذور المعصية، و التتفير منها،

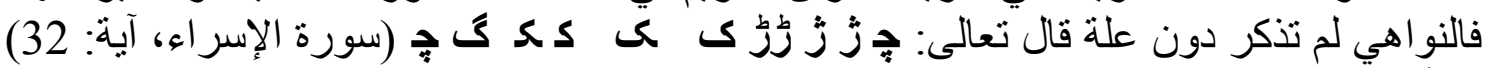

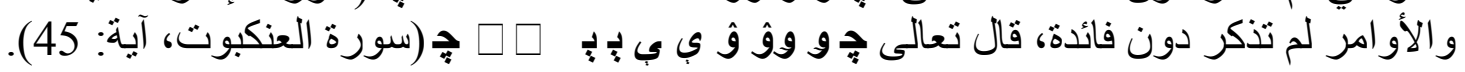

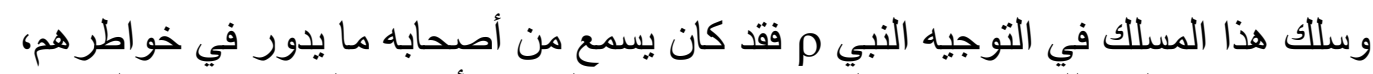

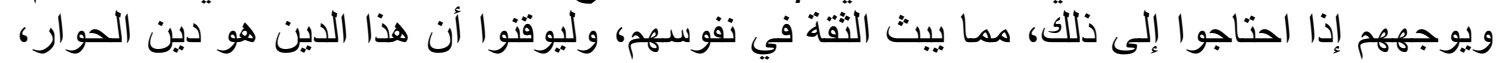

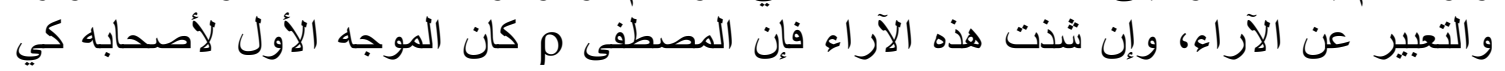

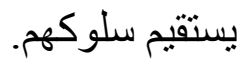

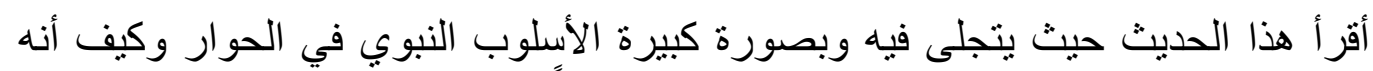

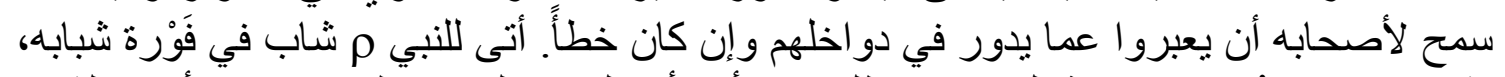

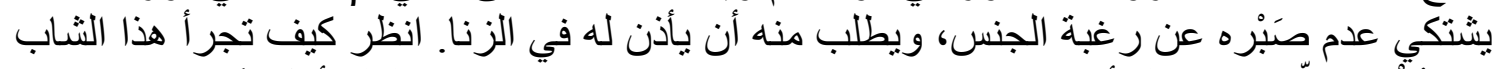

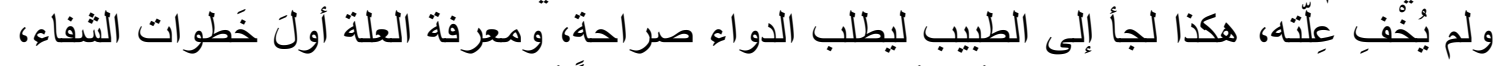

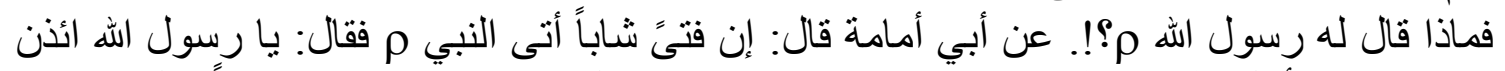

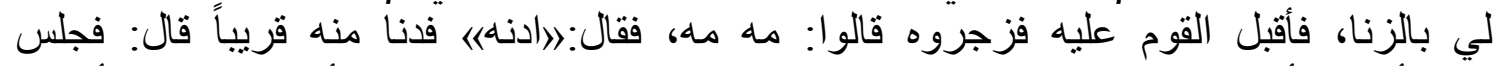

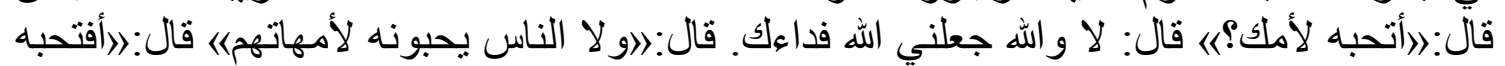

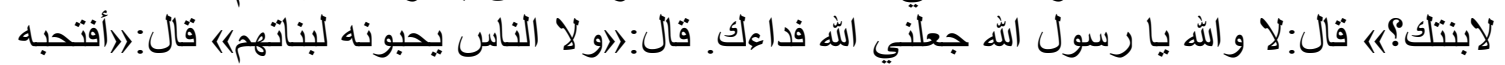

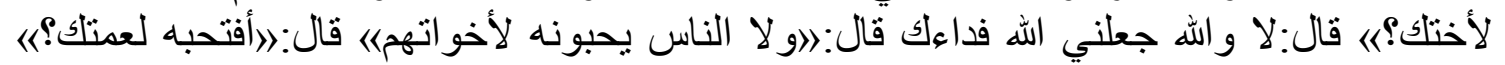

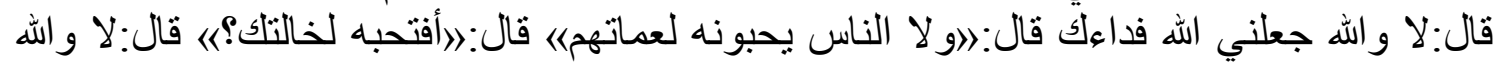

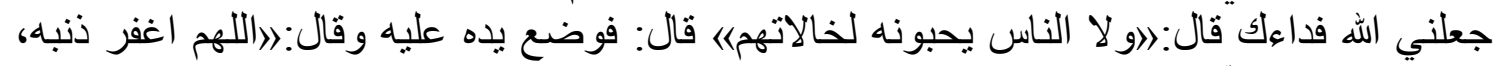
وطهر قلبه، وحصِّن فرجهاء فلم يكن بعد ذللك الفتى يلتفت إلى شيء (ابن حنبل، 545، رقم 22211).

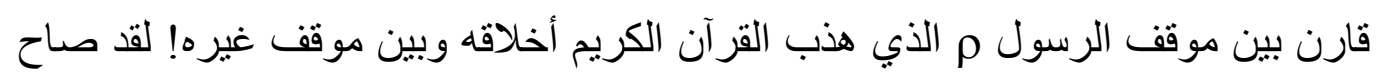

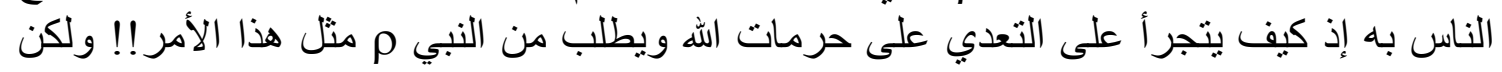


النبي م وجدها فرصة ليخرج من هذا الموقف بدرس يستفيد منه الرجل، ومن حضر ذلك المجلس

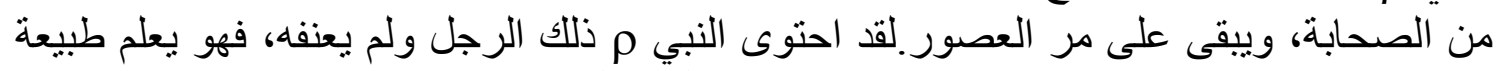

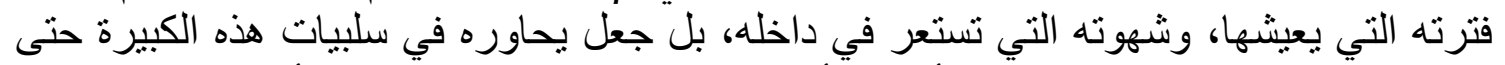

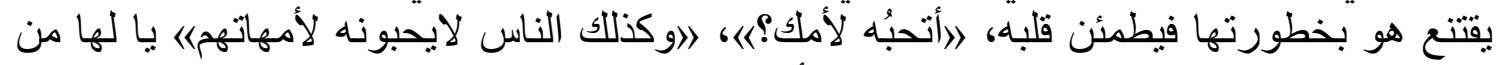

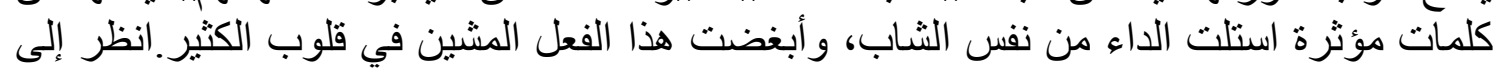

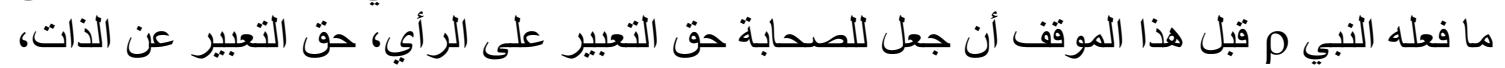

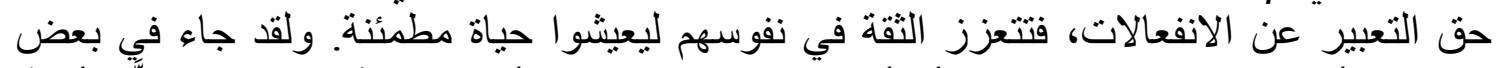

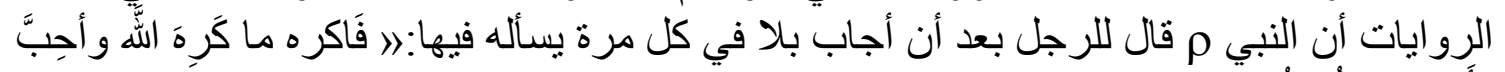

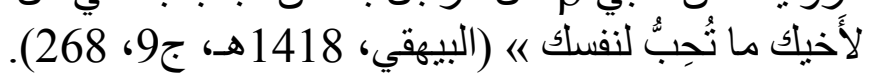

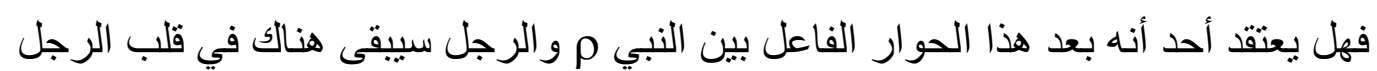

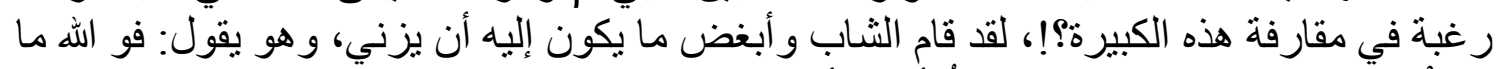

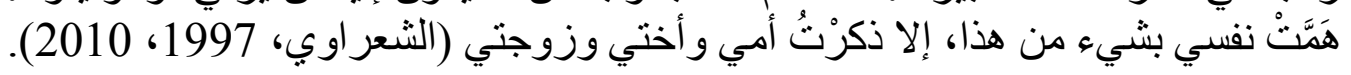

يقول ابن هشام (د. ت، ج1 314): لقد أنى عتبة إلى النبي م حتى جلس إليه فقال: يا ابن فئ

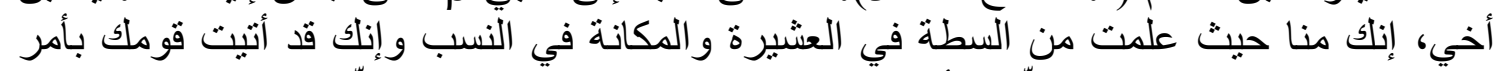

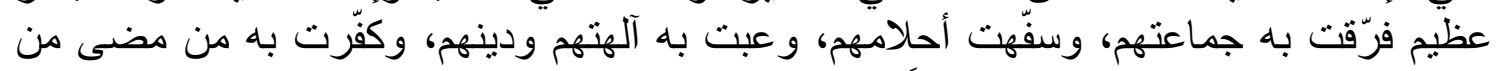

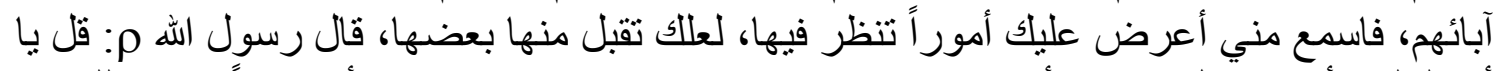

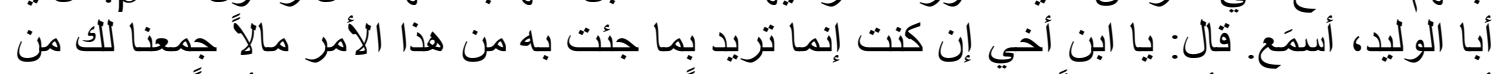

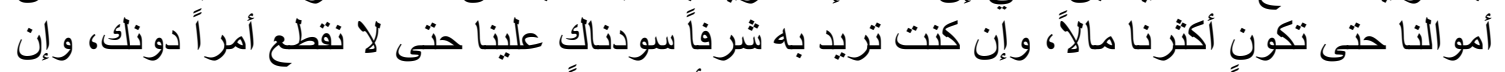

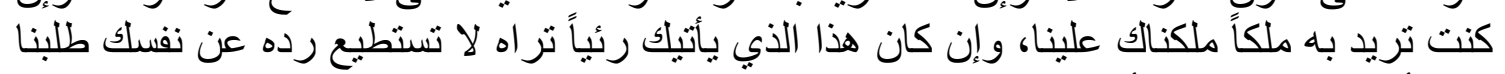

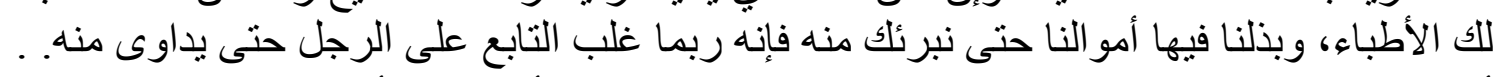

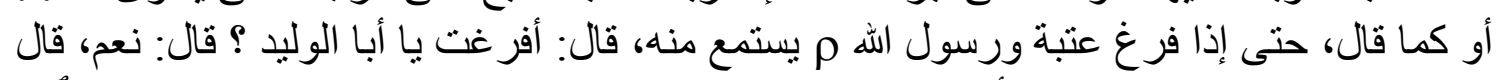

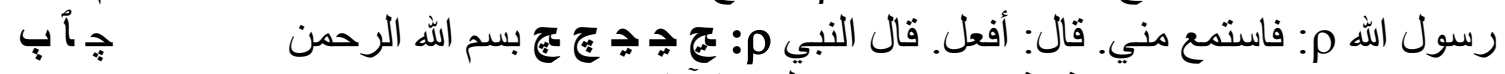

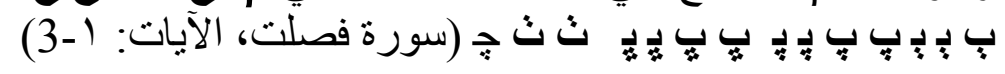

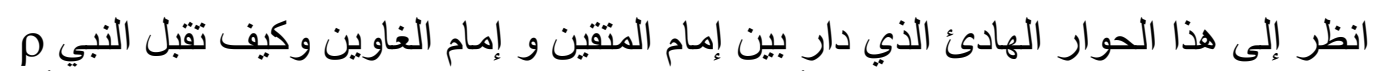

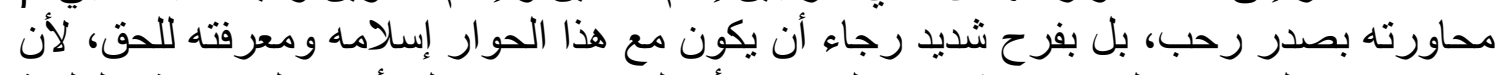

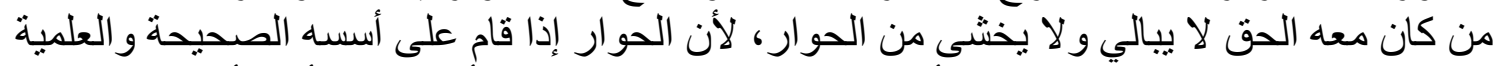

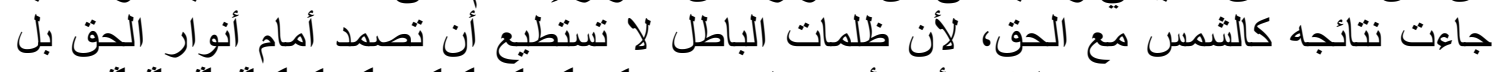

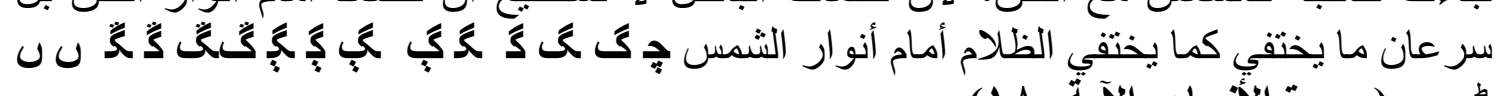
لَج ج) (سورة الأنبياء، الآيةًة: 1 (1).

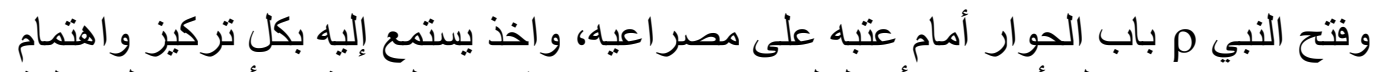

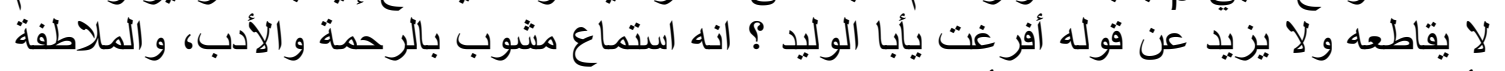

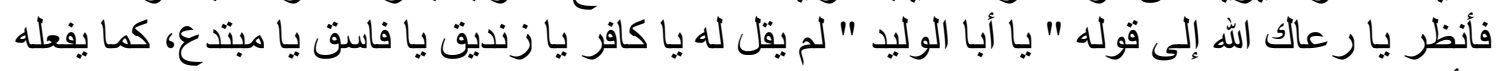

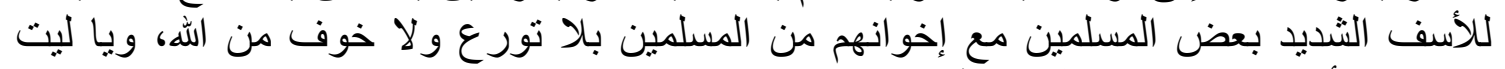

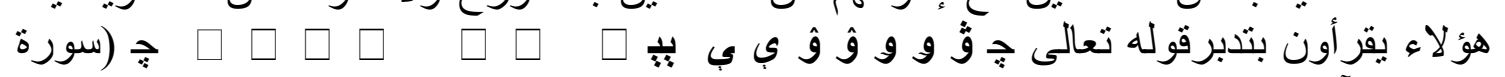

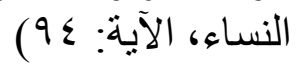

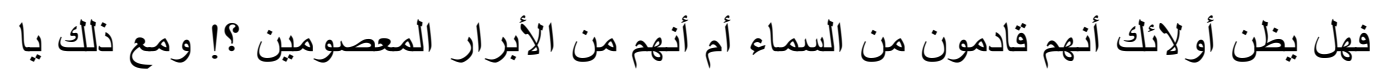

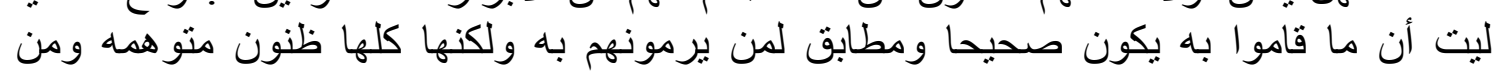
صندوق وكالات يقولون. 
ولنعد إلى النبي لنكمل حواره مع عتبه، ويردد في نهايتها: أفرغت يا أبا الوليد ؟. فيقول:

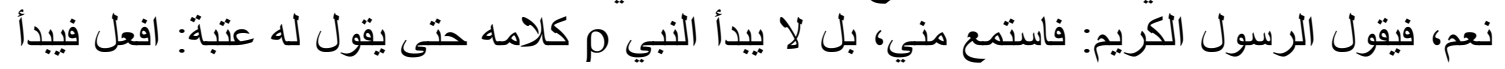

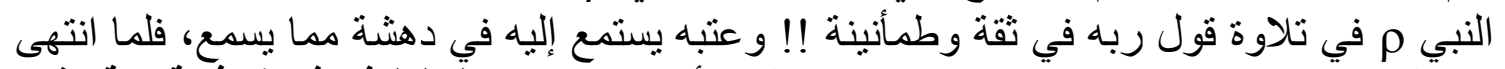

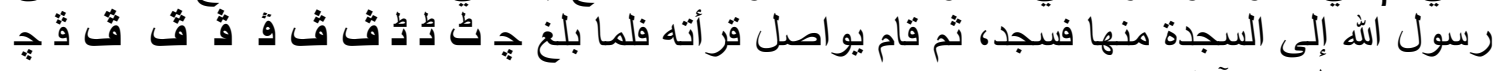

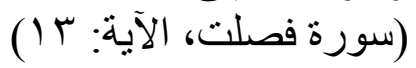

أمسك عتبة بفي رسول الله م، وهو يقول أناشدك الله و الرحم أن تقف، ثم عاد إلى قومه فلما

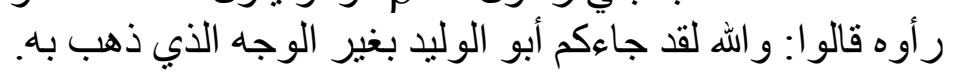

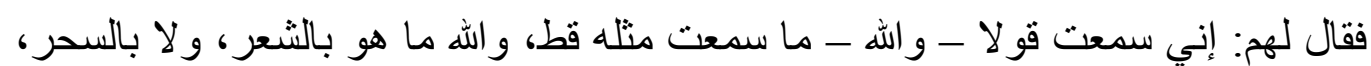

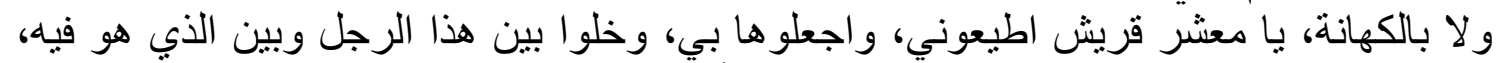

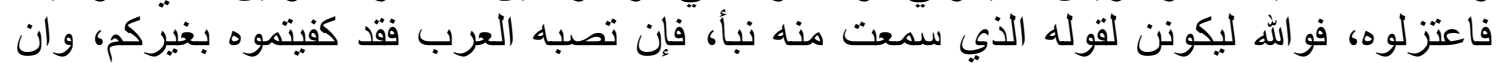

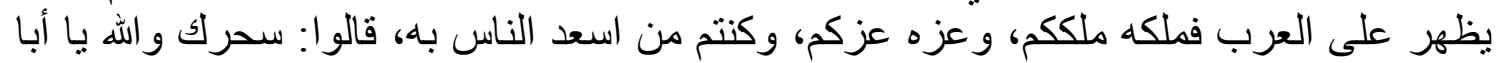

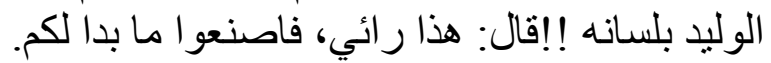

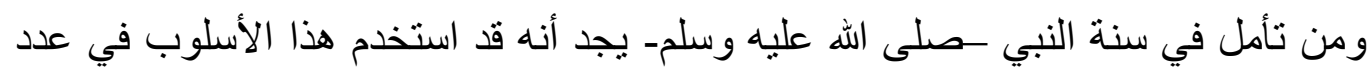

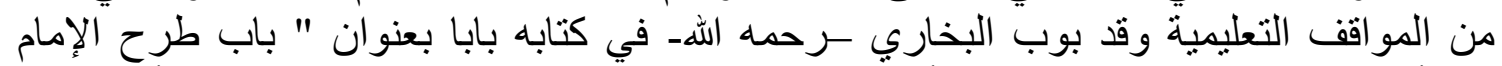

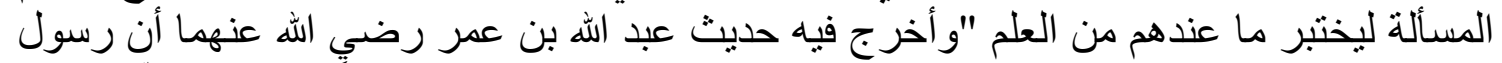

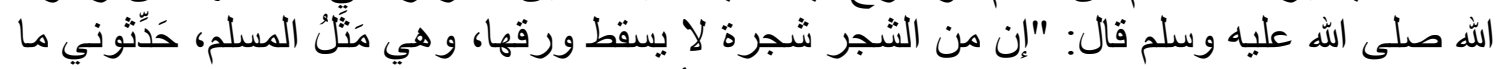

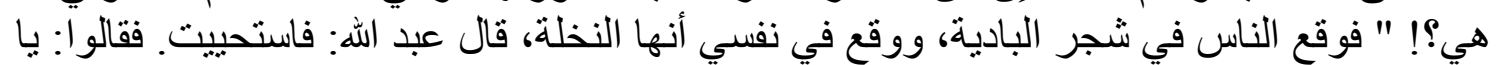

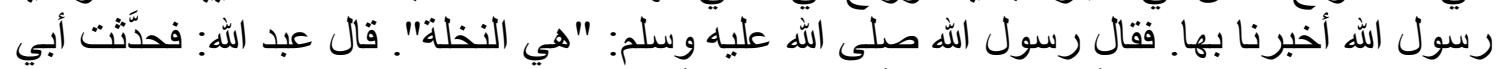

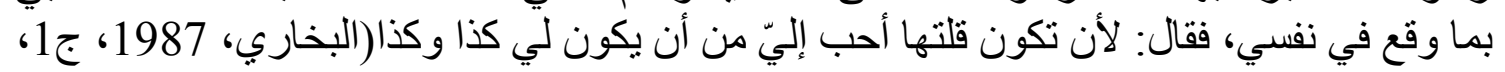

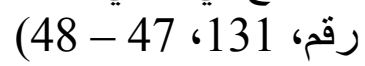

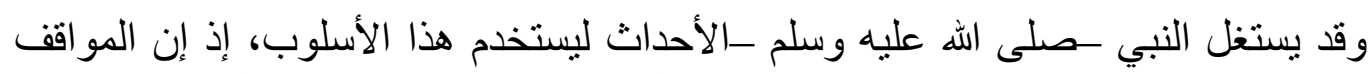

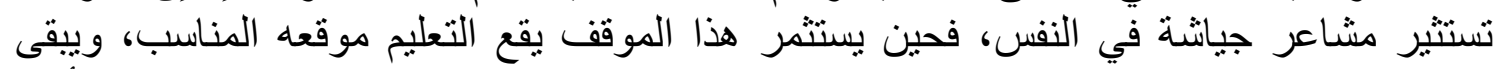

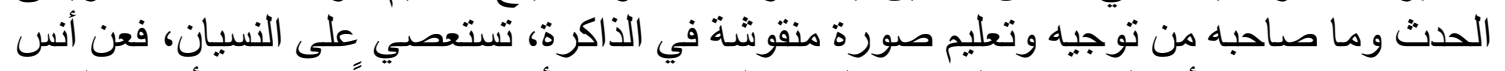

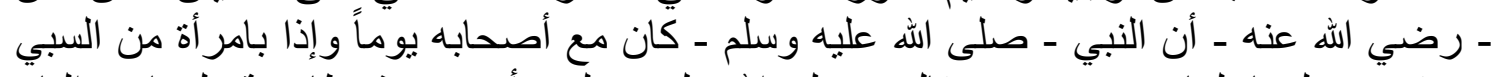

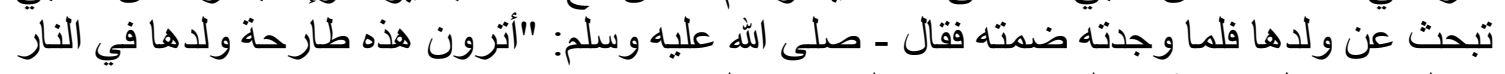

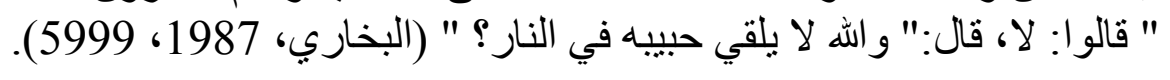

ويمكن تلخيص أهميـة أسـلوب التربيـة بـالحوار بالنسبة للطالب في النقاط التاليـة (معلم،

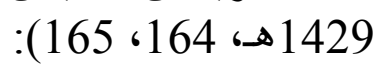

تُُكَكّن الطالب من كسب حب الآخرين و التو اصل معهم. تمنح الطالب القدرة على التأثير في الآخرين و إقناعهم. تساعدهم على تتمية وتطوير وزيادة معار فه و أفكاره و مهار اته. تحفظوتوفر للطالب الكثير من الوقت والجهد. 


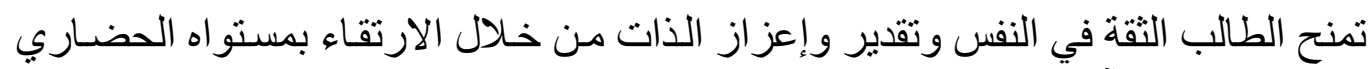

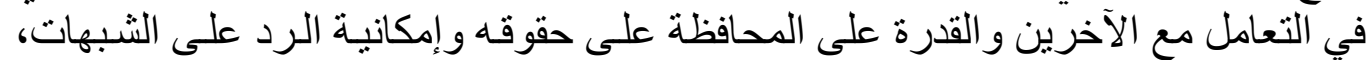
و إجلاء الحقائق و المفاهيم غير الواضحة" (الديب، 1427هـ، 222).

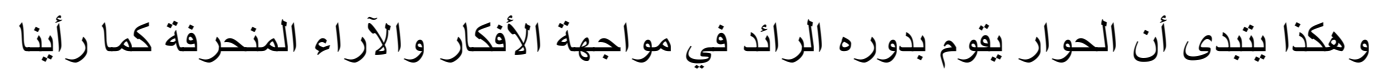

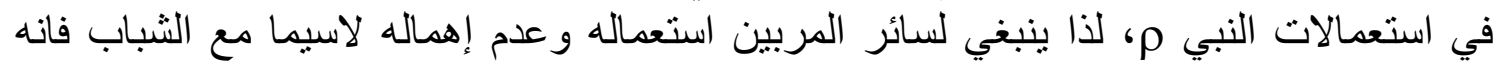

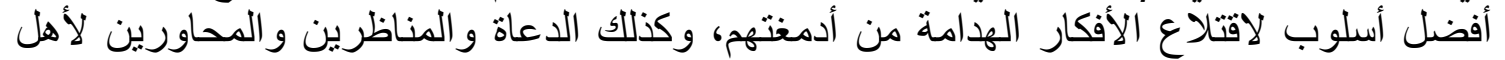

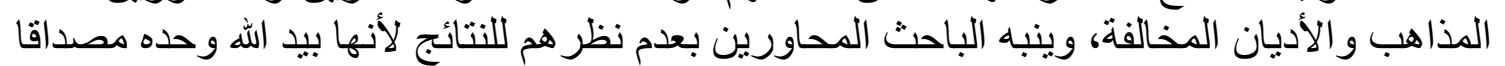

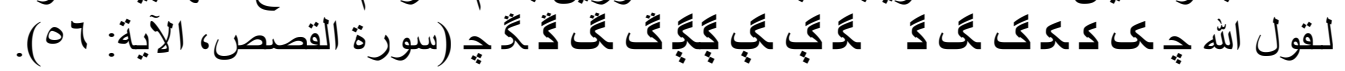

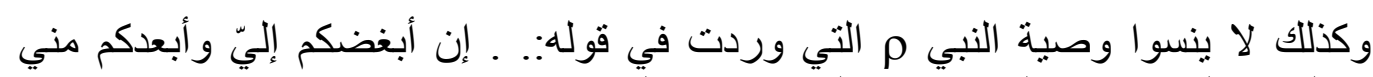

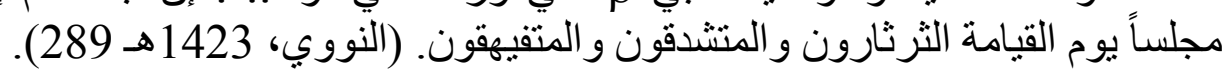

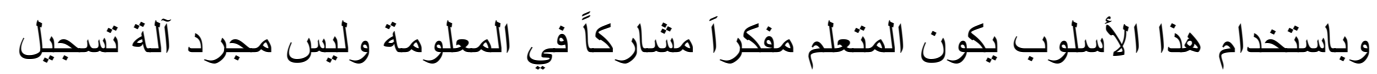
تفرغ فيه المعلومات.

فليُعلم أن الحوار أسلوب إسلامي حضاري أصيل له أهميته ومكانتة التربوية والاجتماعداعية

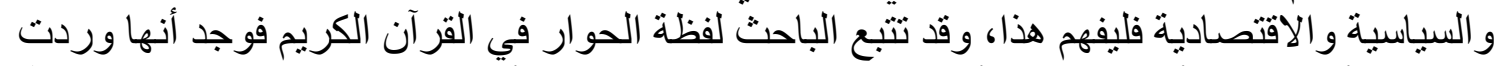

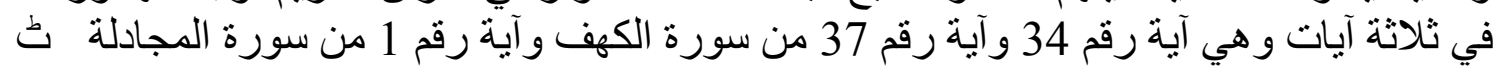

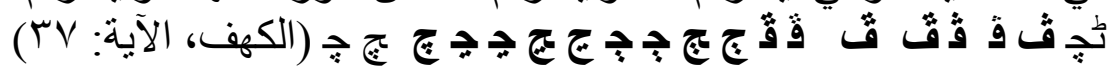

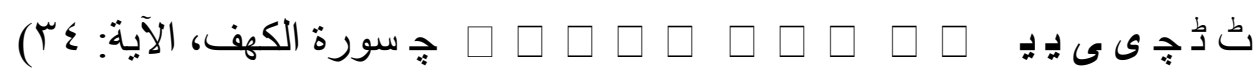

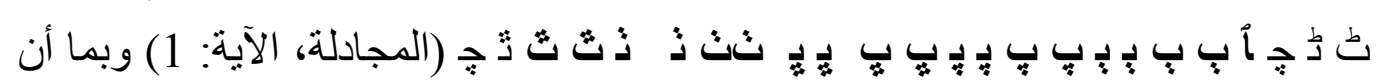

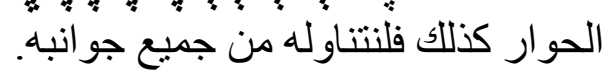

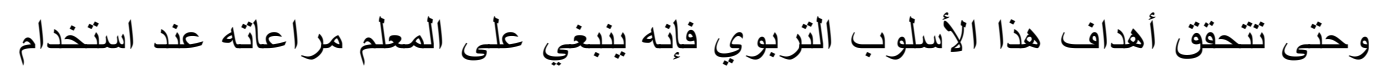

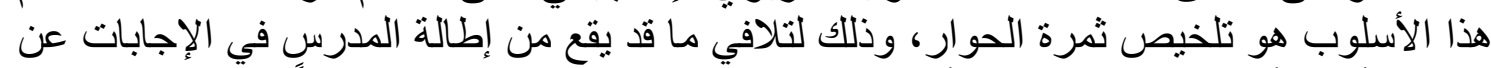

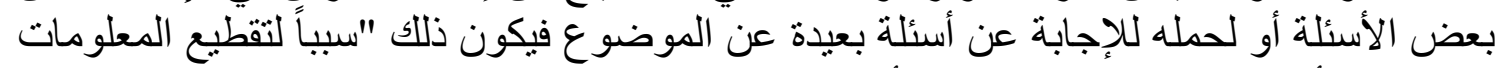

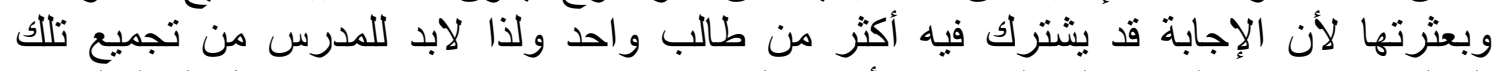

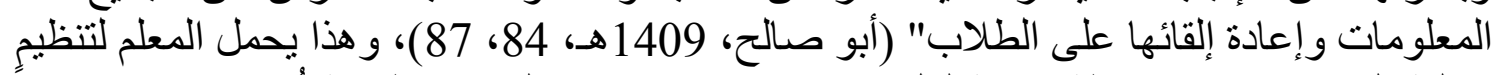

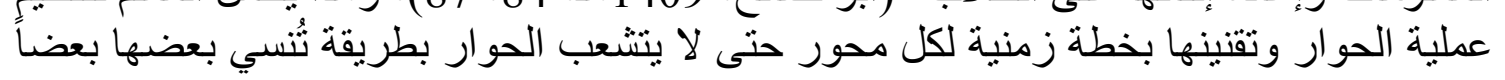
(معلم، 1429 هـ، 166).

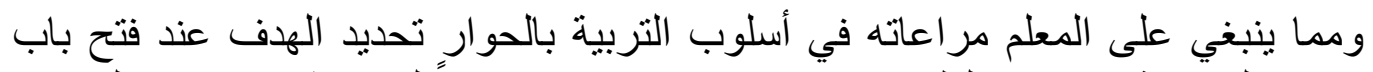

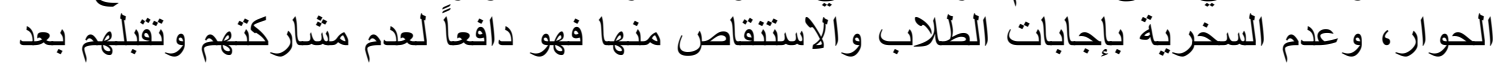

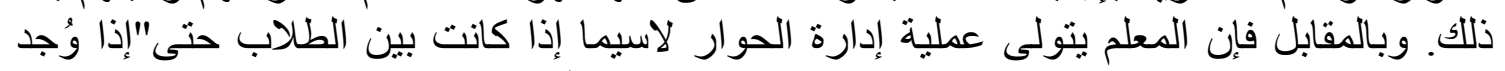

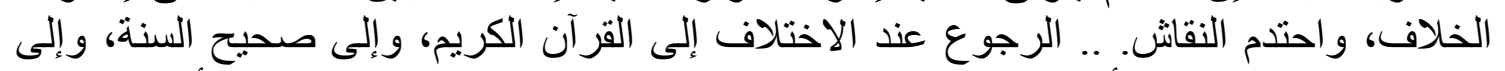

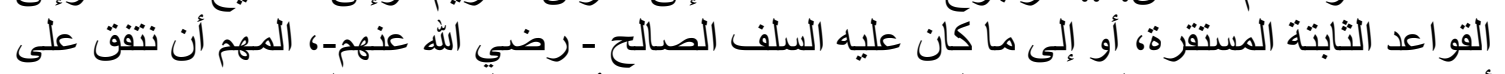

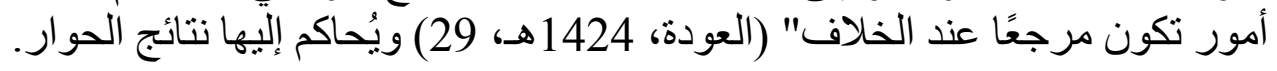
4. أسلوب الميل إلى الرفق في التعليم:

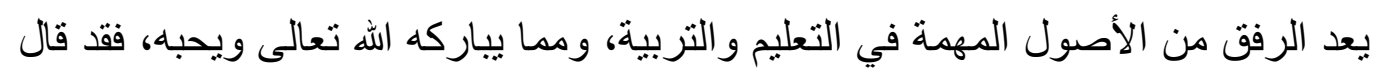

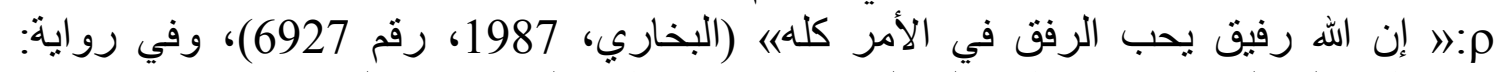

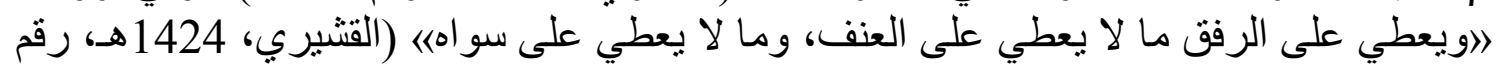




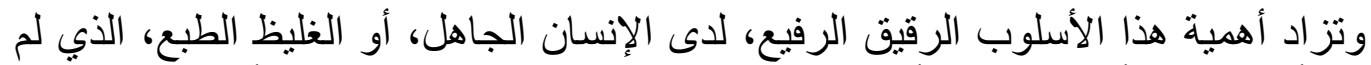

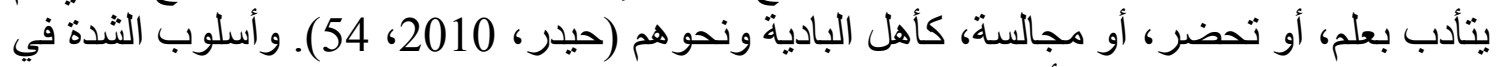

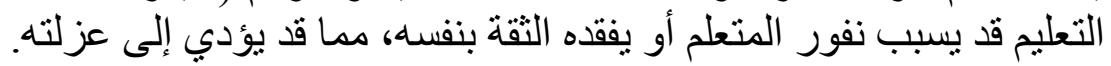

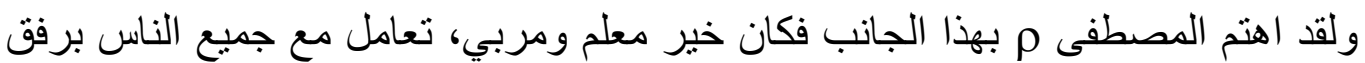

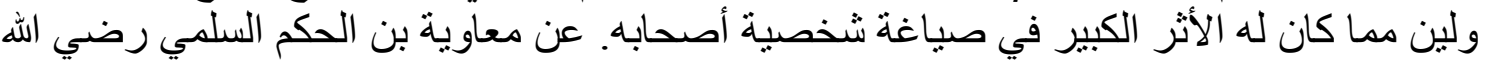

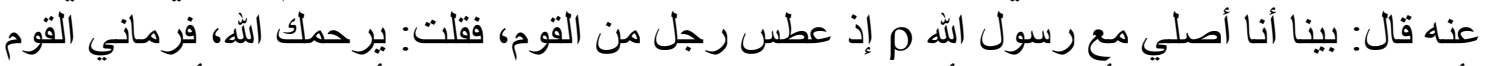

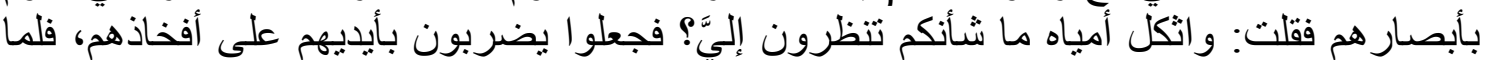

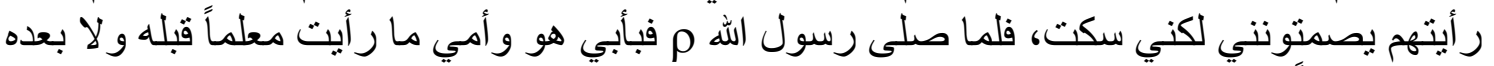

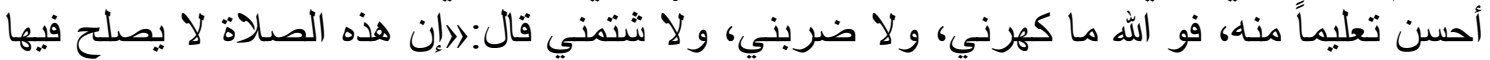
شيء من كلام الناس، إنما هو التسبيح و التكبير وقر اءة القرآنه (القنيري، التيري، 1424هـ، 537).

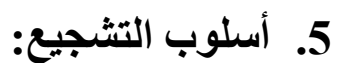

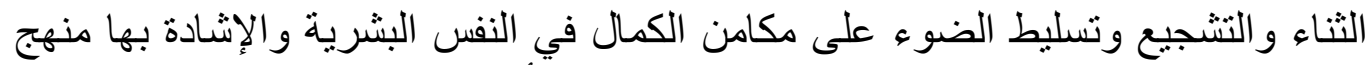

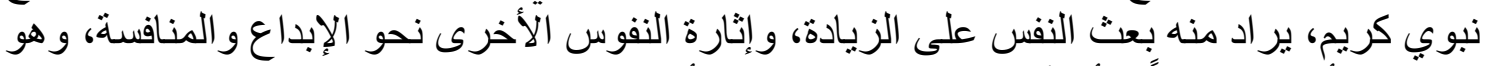

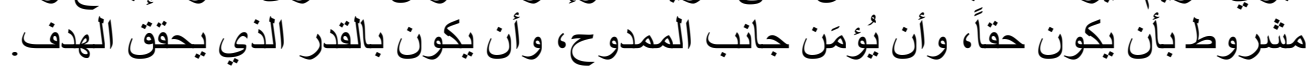

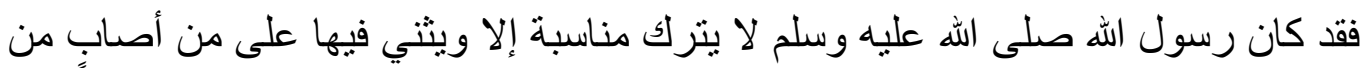

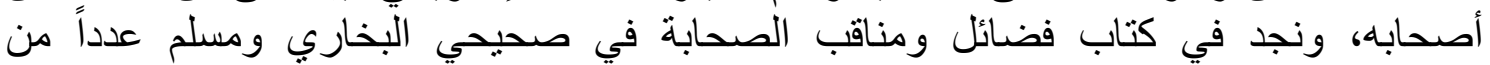

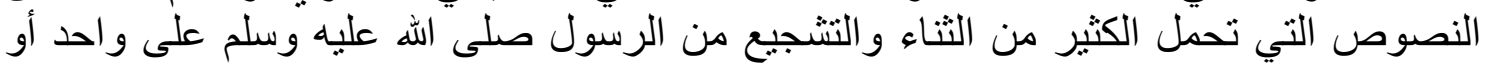

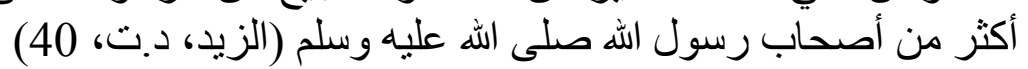

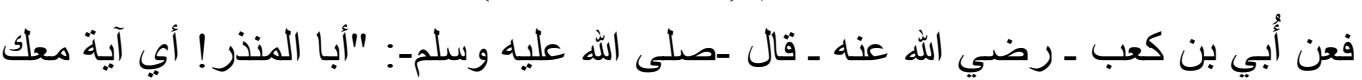

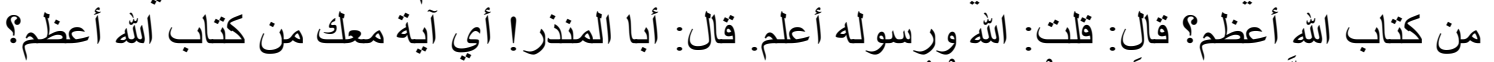

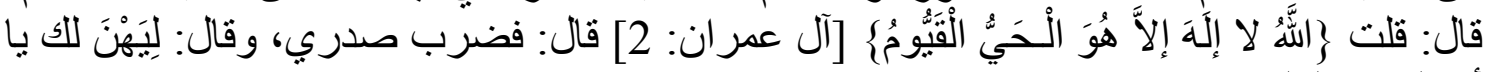

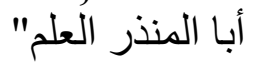

وتارة يفرك أذن المتعلم او يضع يده على كتفه تعبيراً عن الثناء بطريقة عملية.

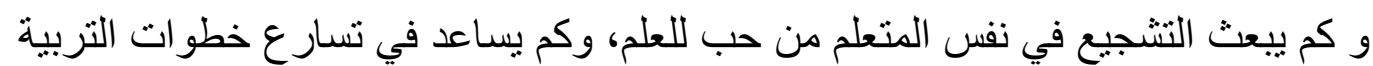

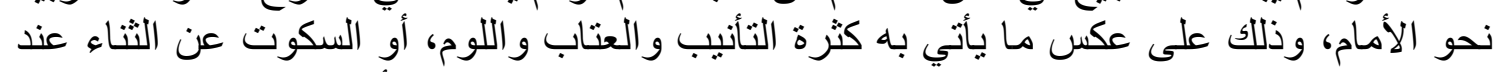

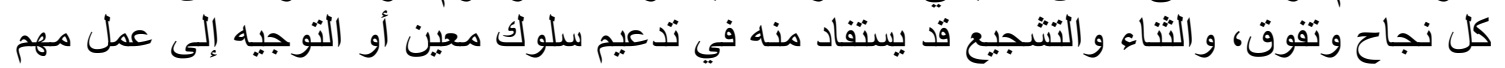

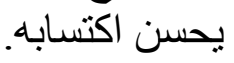

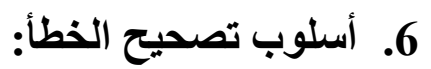
يعرف الثناوي هذا الأسلوب (1998م) بقوله: " هو جزاء أهوباء بسبب الانخراط في السلوك

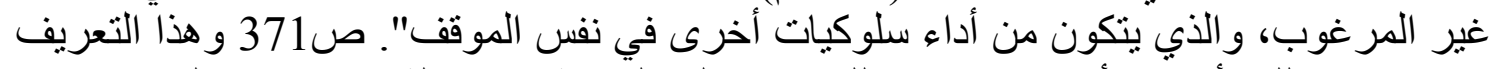

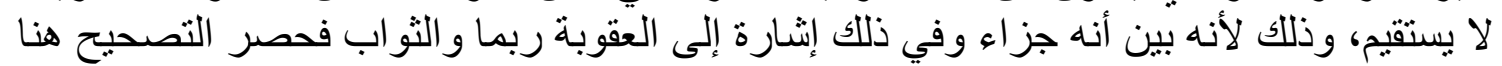
في الجزاء و هذا غير صحيح.

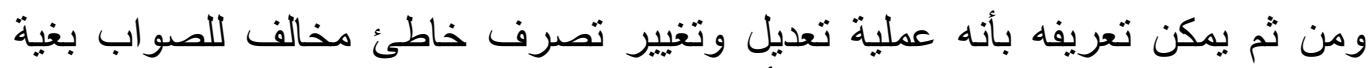
الوصول به إلى التصرف الصحيح الذي ينبغي أن يكون عليه من خلال المو اقف التربونية المختلفية 
زخرت كتب السنن والسير بالأحاديث والمواقف التي استعمل فيها النبي م هذا الأسلوب

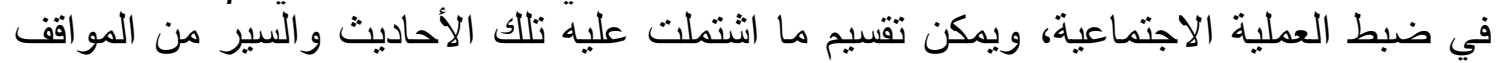

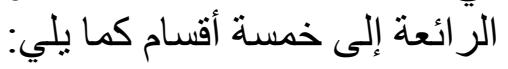

أولاً: تصحيح الخطأ بالتوجيه:

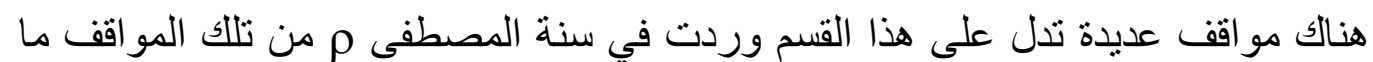

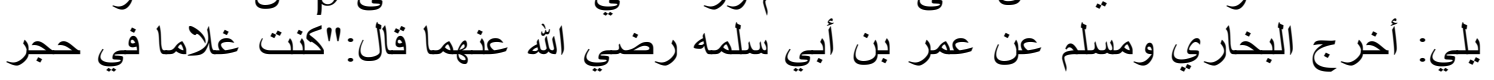

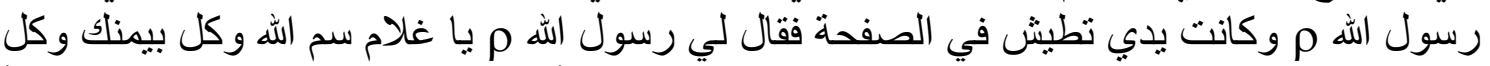

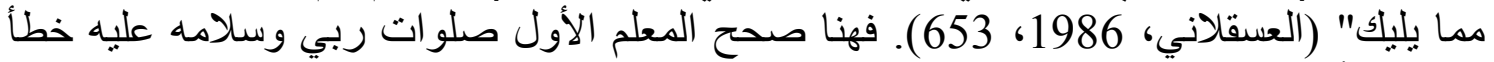

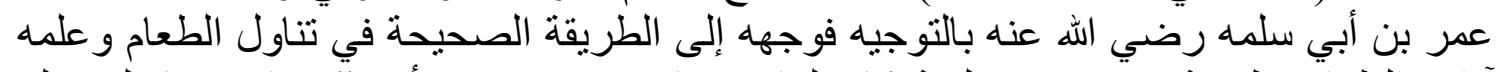

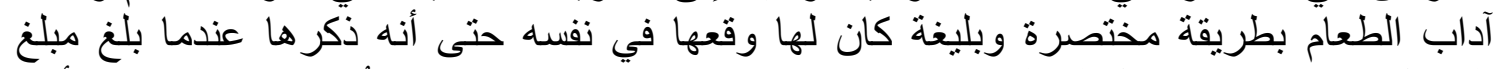

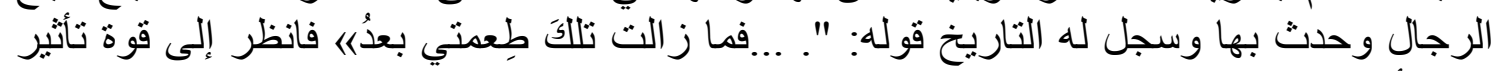
هذا الأسلوب في عملية الضبط الاجتماعي. (العسقلاني، 1986، 1983، 653).

ثانياً: تصحيح الخطأ بالملاحظة:

عن سهل بن سعد رضي الله عنه أن رسول الله م أتى بشر اب فثرب منه و عن يمينه غلام

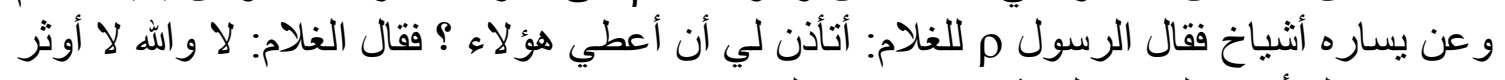

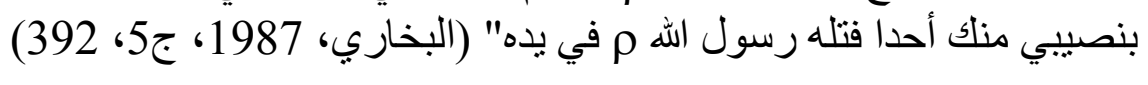

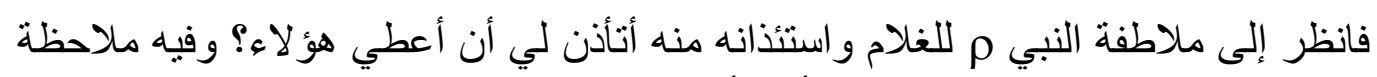

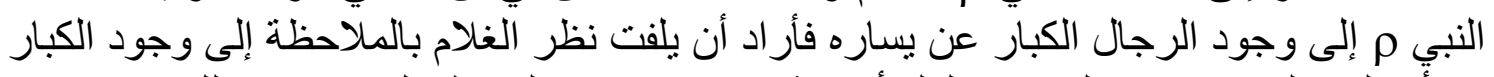

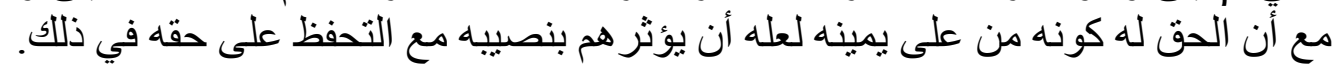

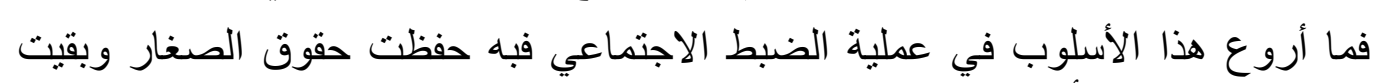
للكبار مكانتهم بدون تعسف أو سحق لكر امة الصغار وحقو فئه الصنه. ثالثاً: تصحيح الخطأ بأسلوب الإشارة:

عن أبن عباس رضي الله عنهما: كان الفضل رديف رسول الله م فجاءت امر أة من خثعم

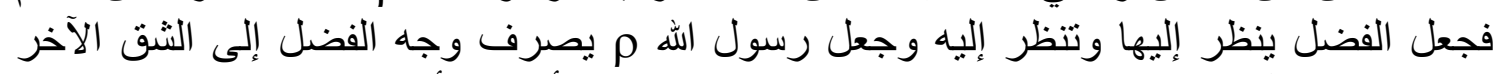

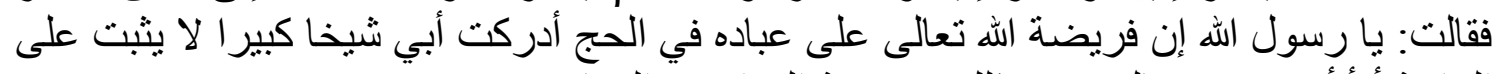

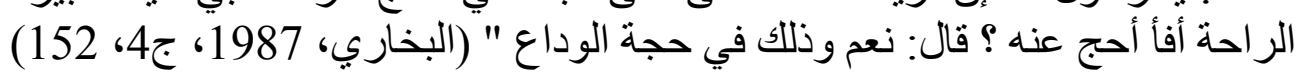
وهذا أسلوب آخر من أساليب الضبط الاجتماعي في تصحيح الخطأ بالإشارة فهنا أخطأ

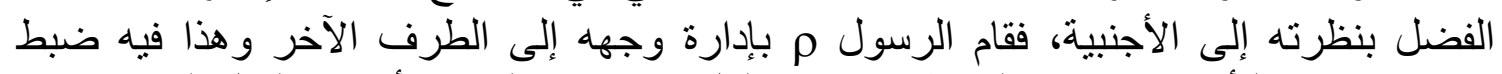

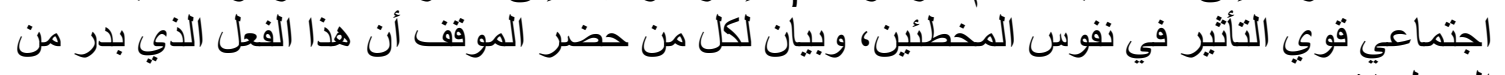
الفضل لا يصنح.

\section{رابعاً: تصحيح الخطأ بالتوبيح:}

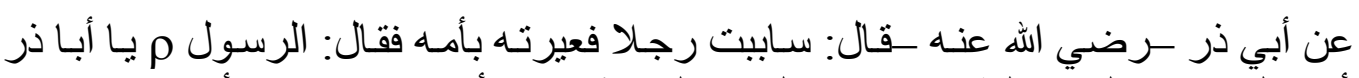

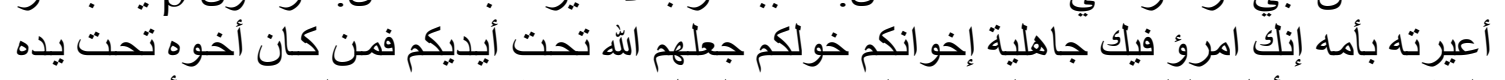

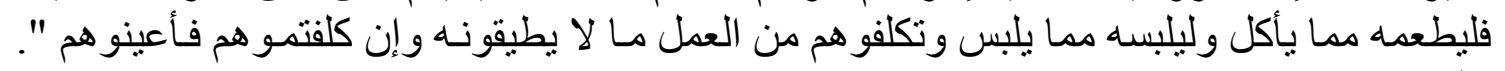

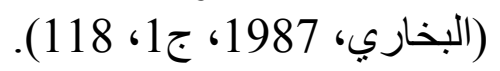




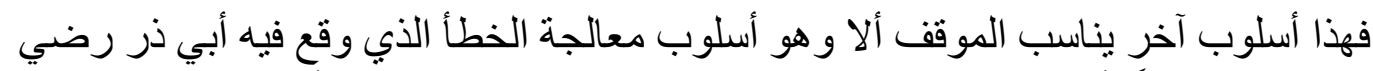

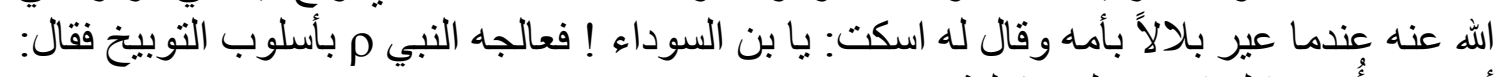

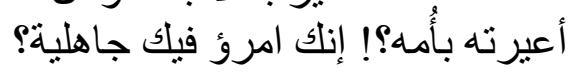

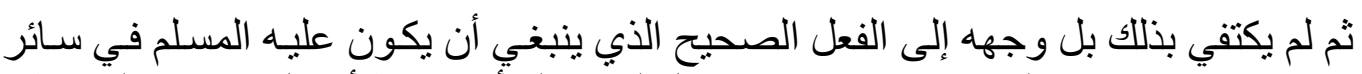

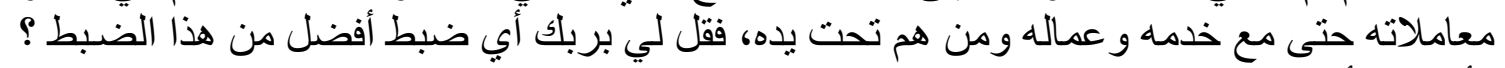
و أب دين أعظم من هذا: هذا: الدين؟ خامساً: تصحيح الخطأ بالإعادة:

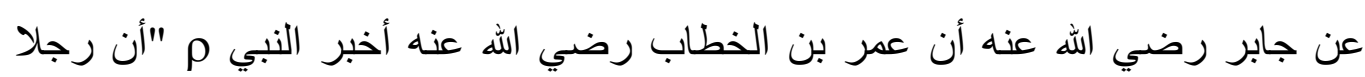

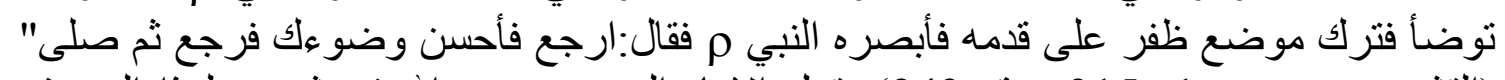

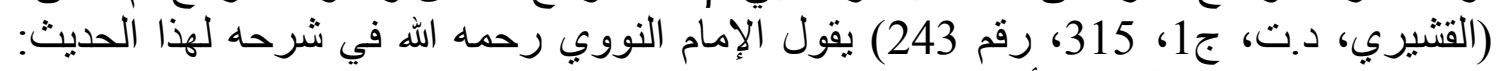

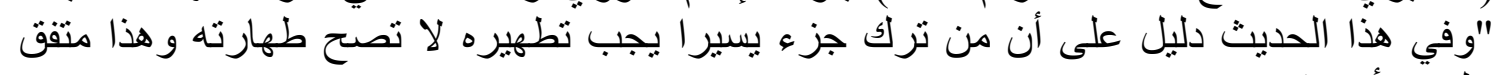

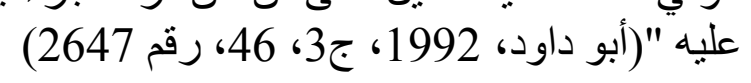

فهذا الموقف من الضوابط التعبدية في المجتمع ومما اتفق عليه سائر العلماء أنقاء أن العبادات

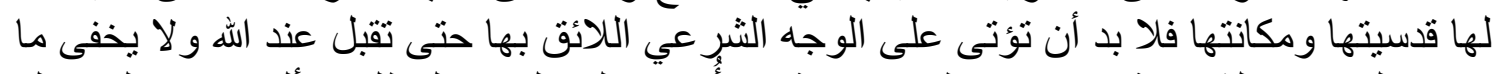

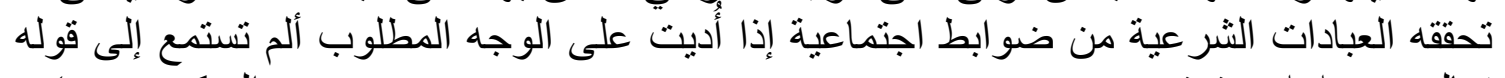

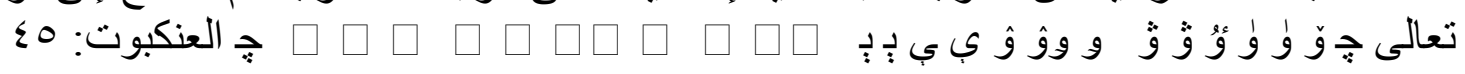

وقد بسط الباحث الحديث حول ذؤ ذللك في الفصل الأول فليرجع له لمن أراد الاستز ادة. سادساً: تصحيح الخطأ بإصلاح ما ترتب على الخطأ من ضرر أكبر:

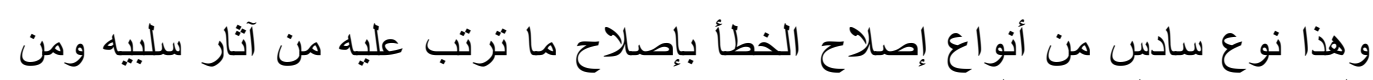
المو اقف التي تؤيد هذا النوع ما يلي:

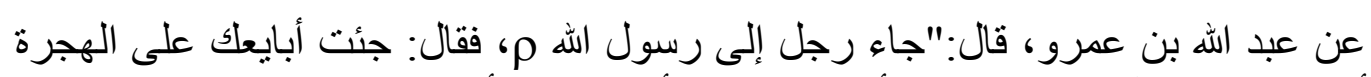

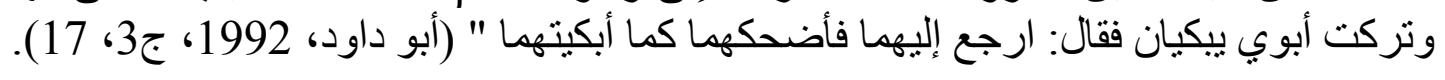

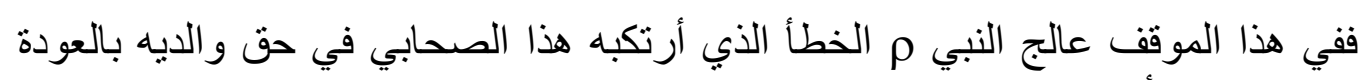
إليهما لإضحاكهما كما أبكاهما.

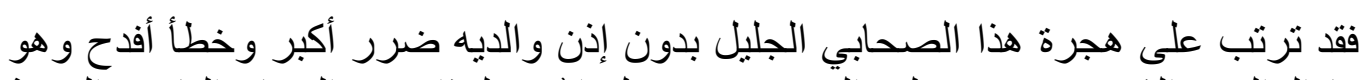

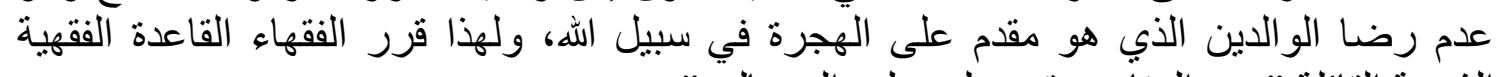

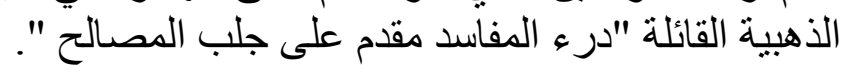

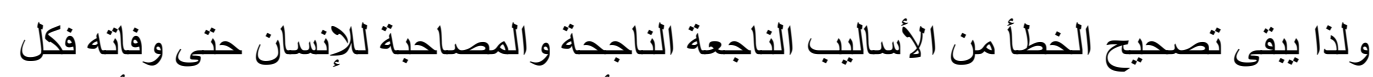

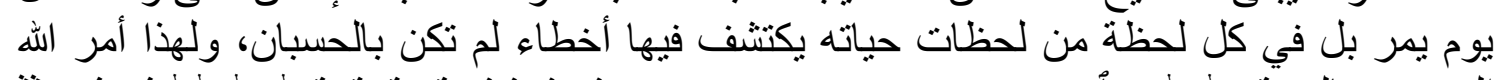

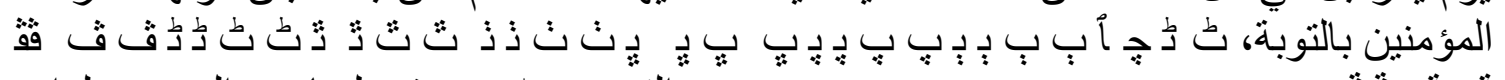

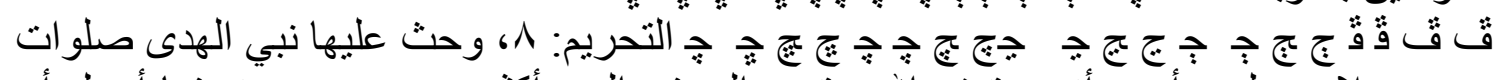

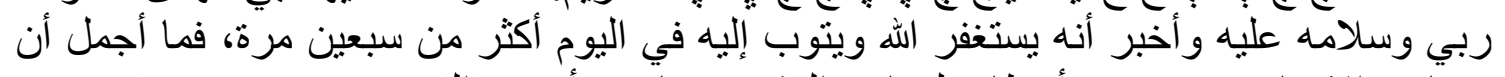

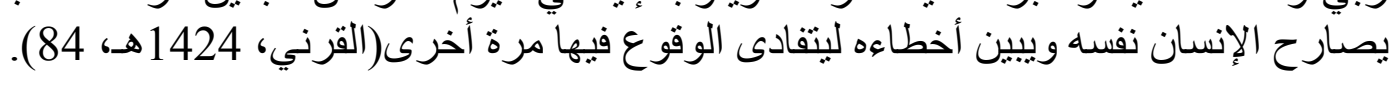




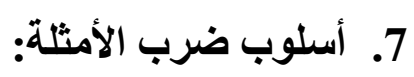

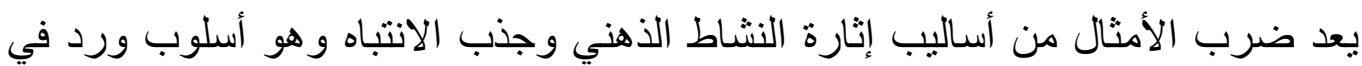
القرآن الكريم والسنة النبوية المطهرة قال تعالى: (ويضرب الله الأمثنال للناس لعلهم يتذكرون) (سورة إبر اهيم: آية25) الكردم)

و أسلوب ضرب المثل "يعتمد على تصوير المعاني وتحليلها، وهو أسلوب تربوبي عظيم

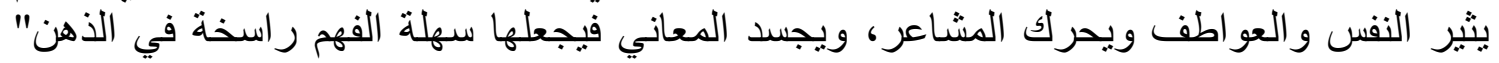
(العجمي، 1425 هـ، 168).

كما يعد أسلوب ضرب الأمثال، والتشبيهات، من أهم الأساليب في عملية التربية، خاصة

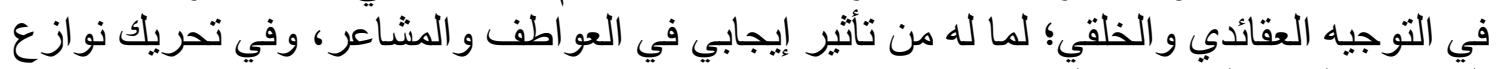

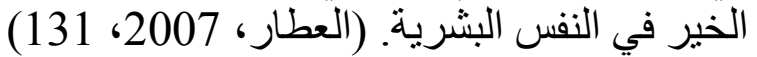
وقد عرّف المنل بأنه (تشبيه شيء بشيء في حكمه وتقريب المعقول من المحسوس أو أحد

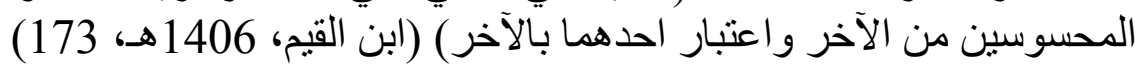

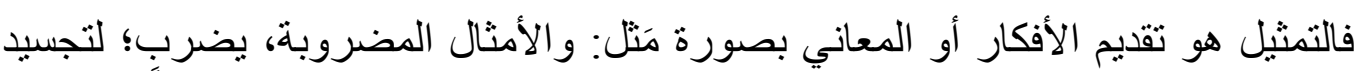

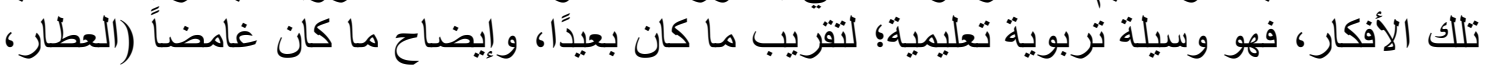
(131، 2007

وكان رسول الله صلى الله عليه وسلم يستخدم ضرب الأمثنال في مو اقف كثيرة ومن ذللك ما

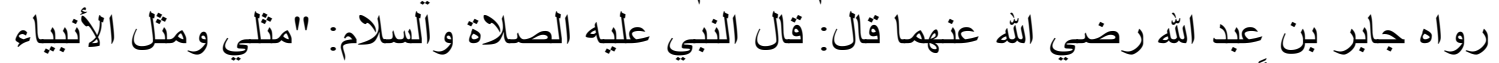

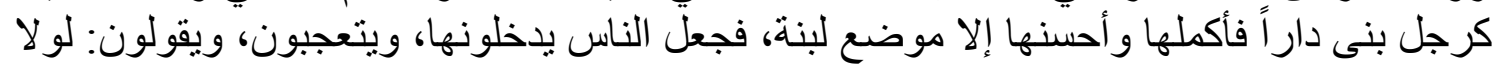

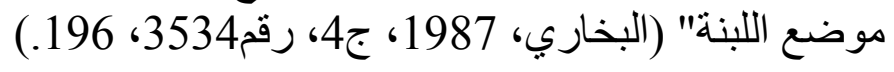
وقال صلى الله عليه وسلم: " إنما منل الجليس الصالح وجليس السوء، كحامل المسك ونافخ الكير. ..." (القشيري، 1424 هـ، رقم 2628).

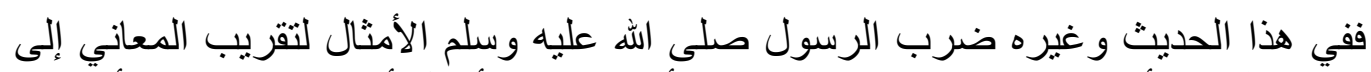

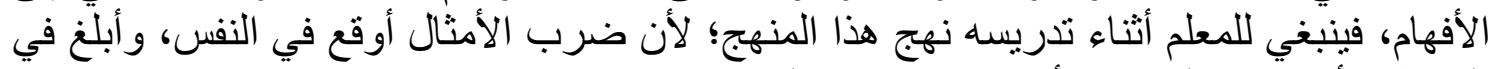

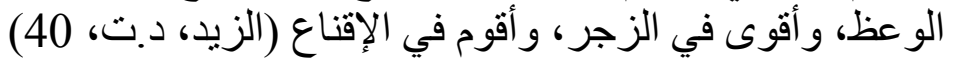
و استخدم النبيم ضرب الأمثال كأسلوب من أساليب الدعوة إلى العقيدة، فهو من أقوى الأدلة في إبراز الحقائق. و الغرض من ضرب الأمثال نتبيه الخفي بالجلي، و الغائب بالثـاهد، فيصير الحس مطابقاً للعقل، وذلك هو النهاية في الإيضاح.

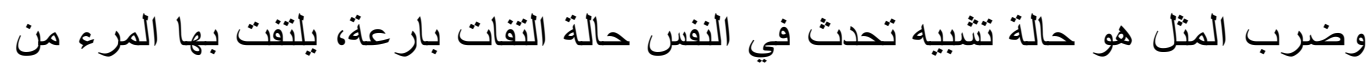

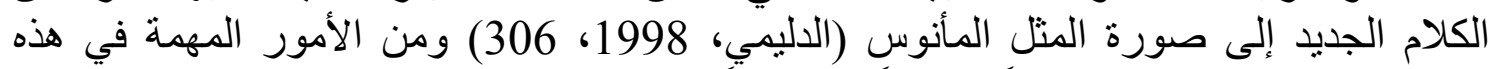

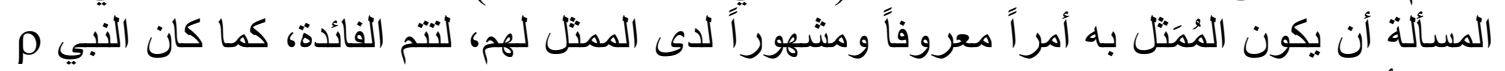

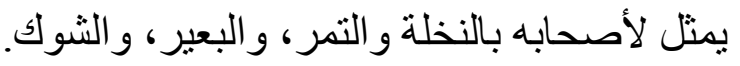

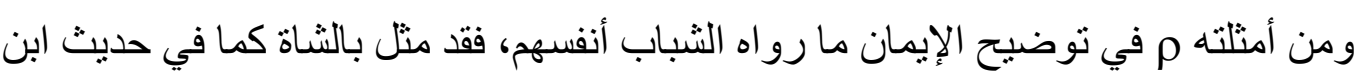

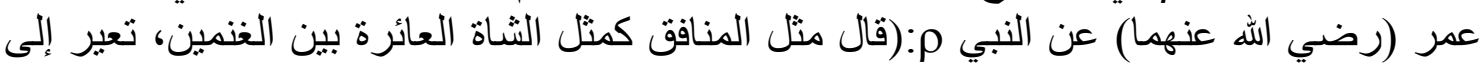

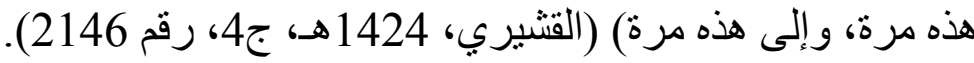


ومثل بالشوك كما يرويه أبو هريرة وأبو سعيد الخدري (رضي الله عنهما) فيقول: (...وفي في إنها

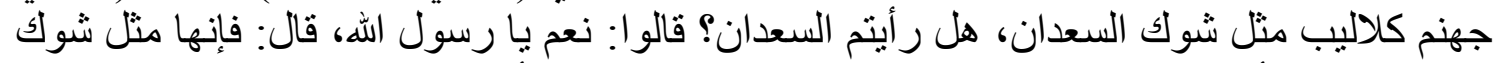

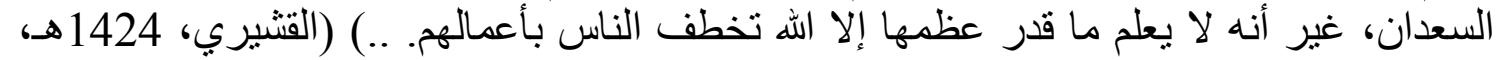

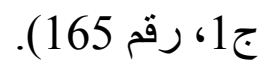

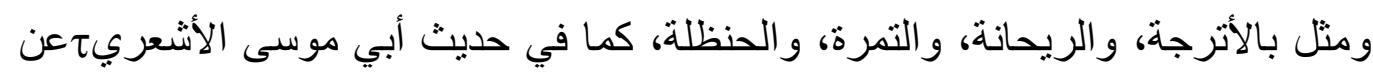

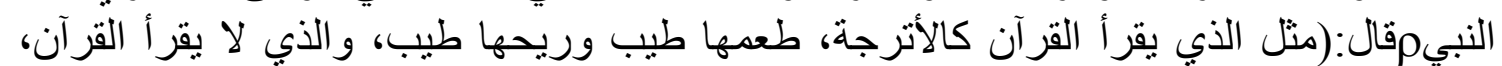

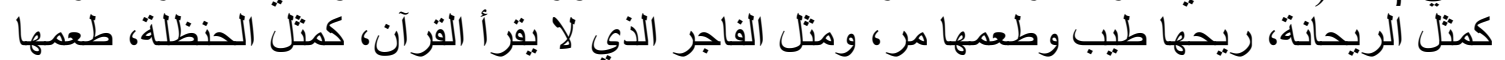

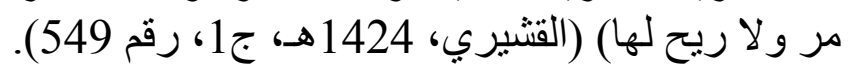

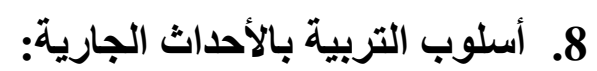

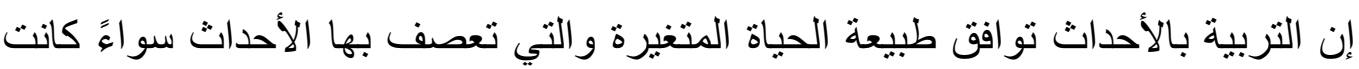

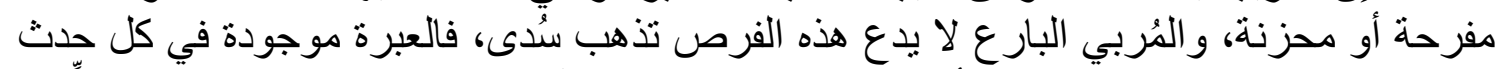

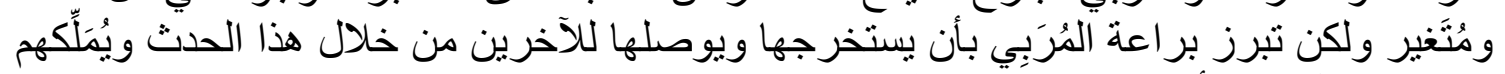

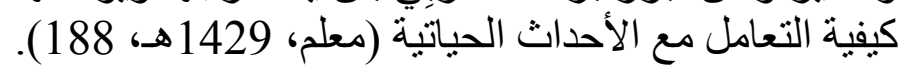

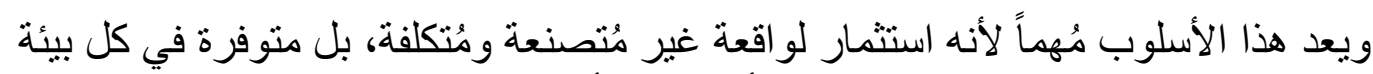

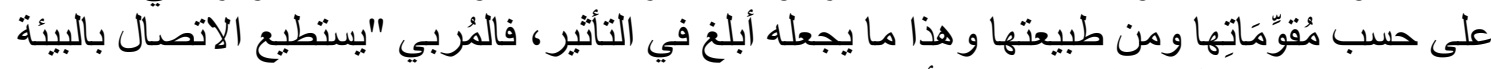

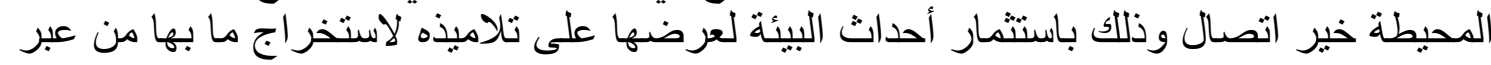

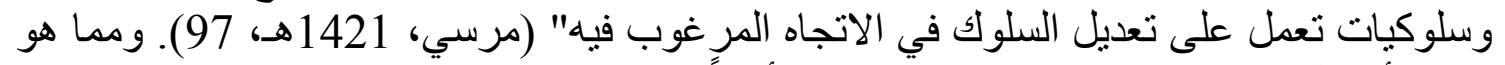

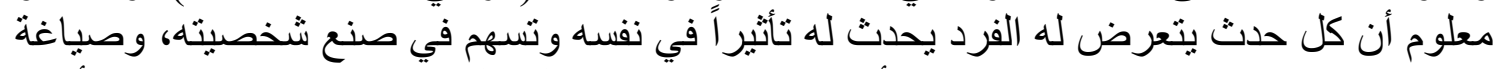

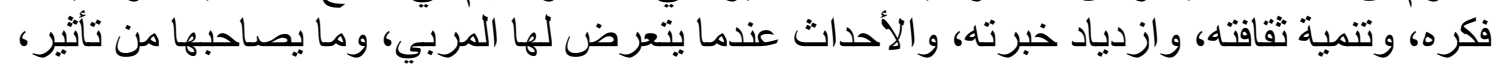

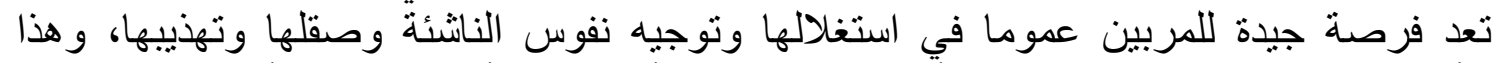

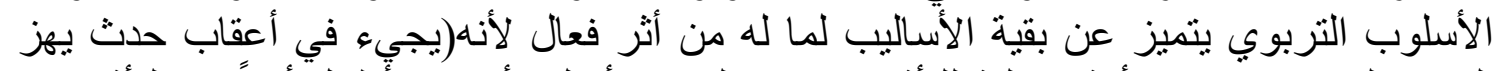

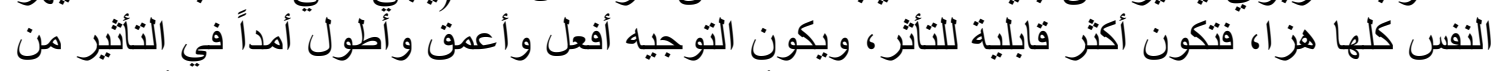

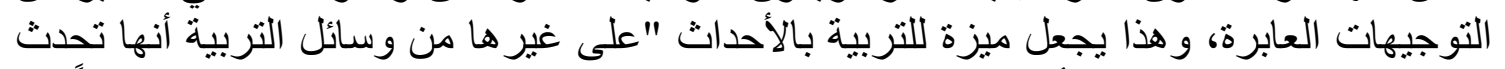

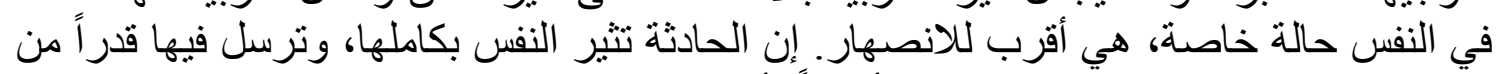

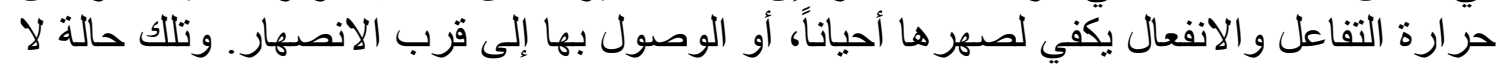

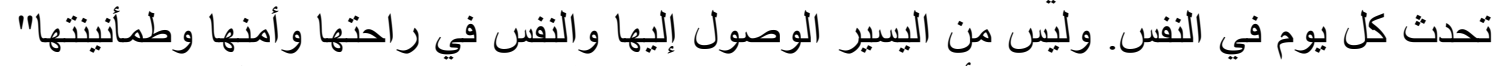
(قطب، 2011، 207، 208)، فالأحداث في الغالب تثير حالة في النفس من الداخل تحقيق التهيول التهيؤ الذهني التقبل المعلومات و التوجيهات.

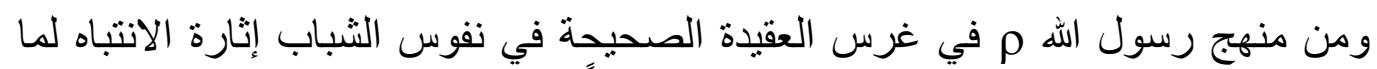

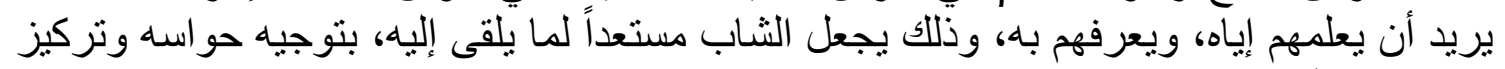

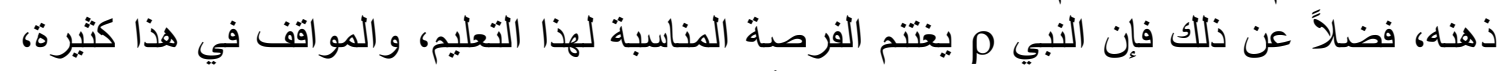

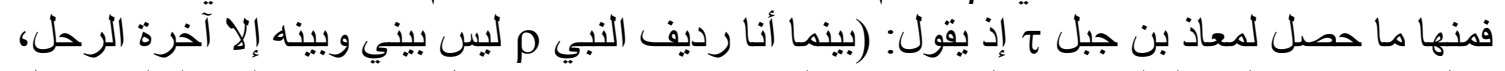

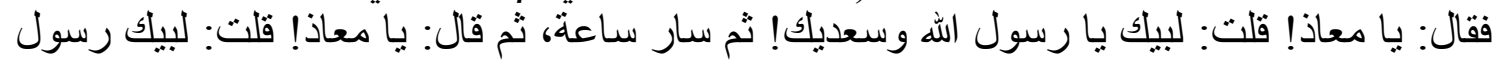

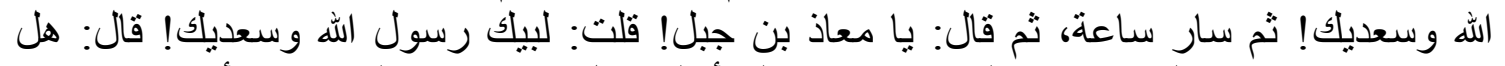

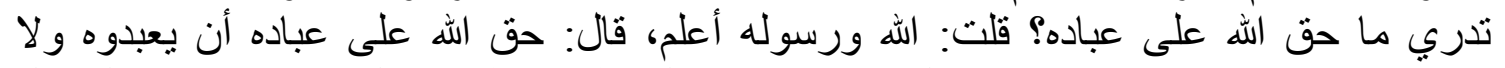

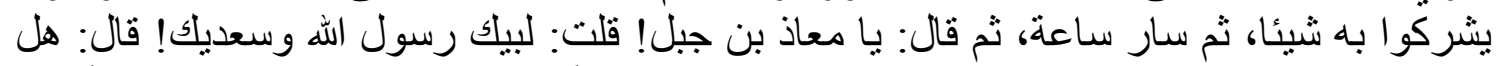

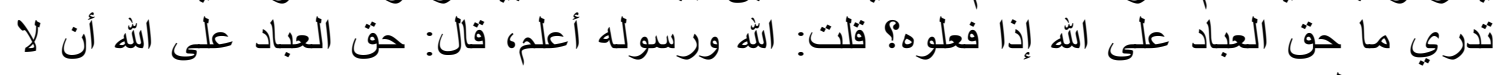

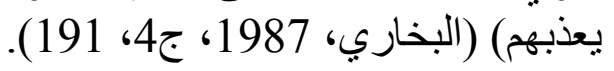


وتلقى معاذ بن جبل ح درساً بليغاً في العقبدة، وقد تأثر به تأثر اً شديداً، مما جعله لا يكتفي

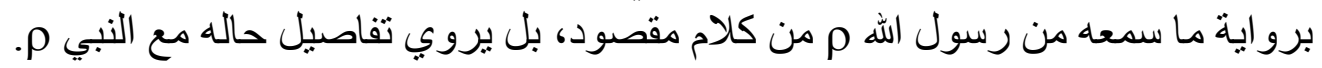

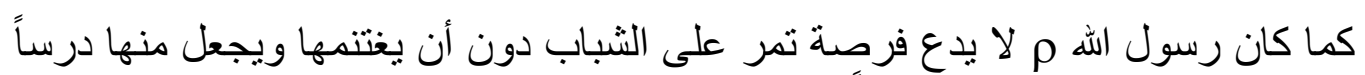

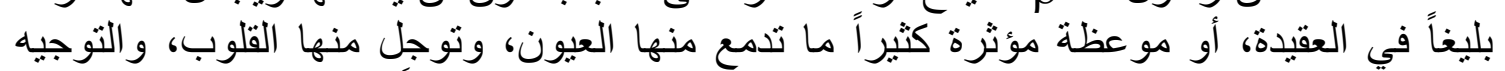

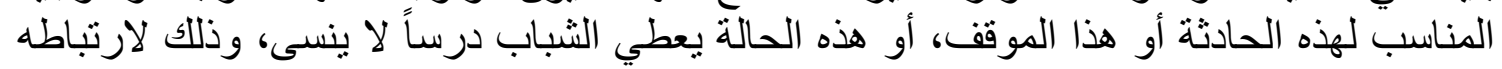
بهذا الو اقع المشاهد.

ومن أمثلة اغتنام الفرص فيما رواه علي بن أبي طالب ح قال: كنا في جنازة في بقيع

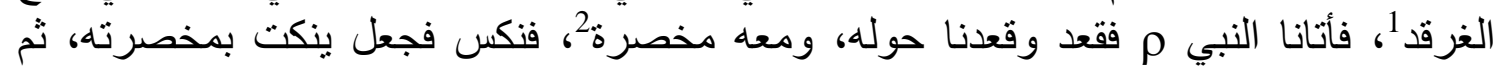

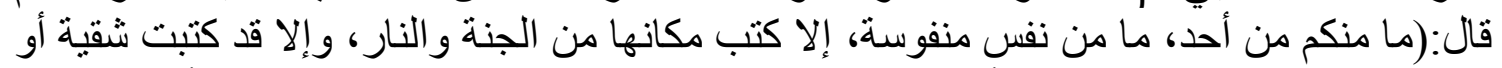

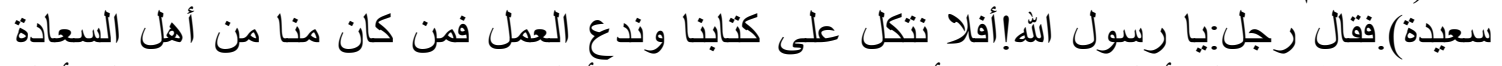

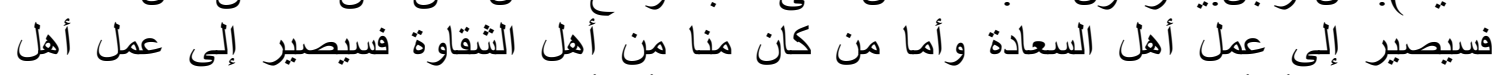

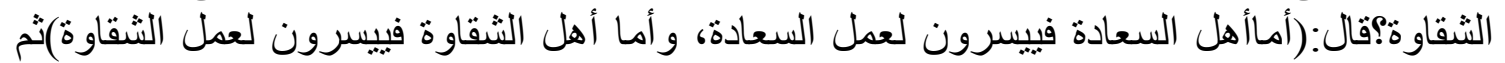

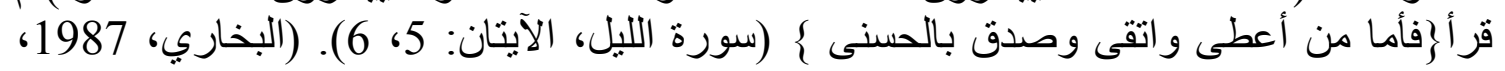

(418، (4)

ومن أمثلة التربية بالأحداث الجارية ما رواه ابن عبد الوهاب (د.ت، 442) أنه قال: وفي الوبي

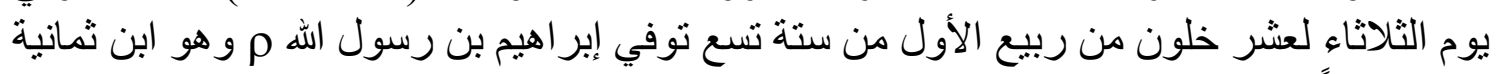

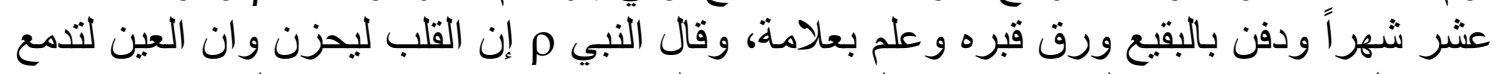

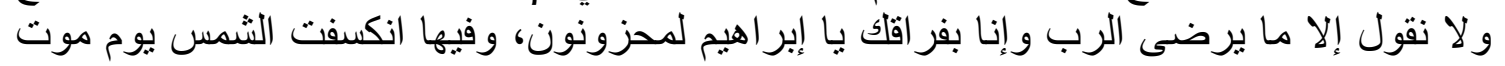

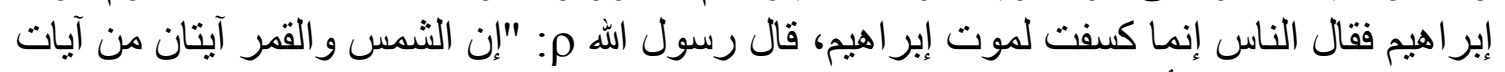

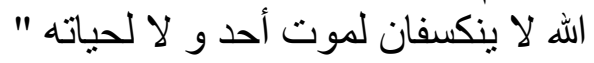

فهذا الحدث من أعظم الحو ادث التي حصلت في زمن النبي م ويمكن أن يستفاد منه ما يلي:

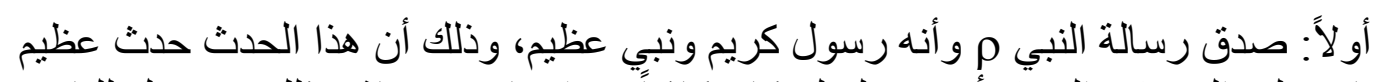

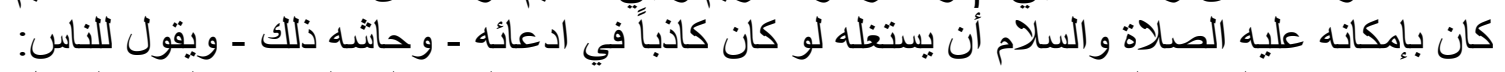

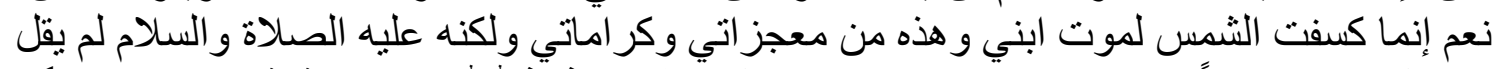

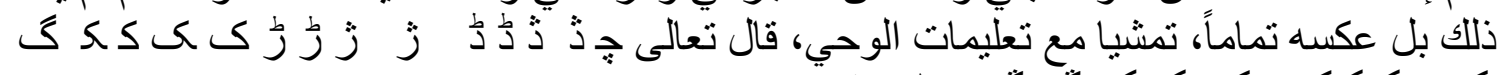

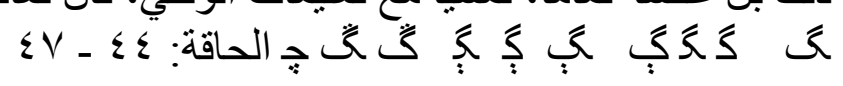

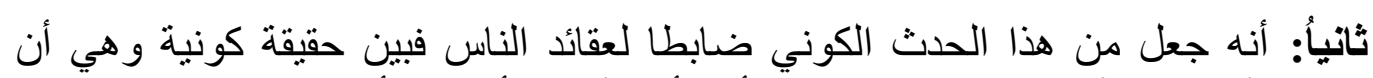

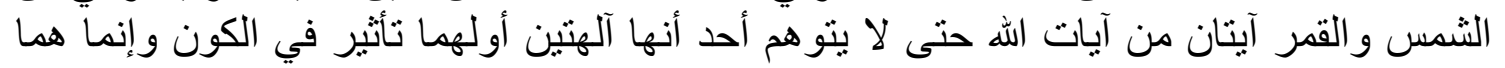

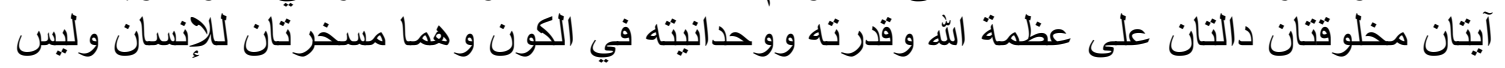

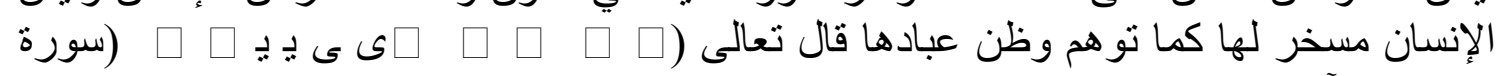

إبر اهيم، الآية: مبين مان)

1: أصل البقيع في اللغة الموضع الذي فيه أروم الثجر من ضروب شتىى، وبـه سمي بقيع الغرقد، والغرقد كبار

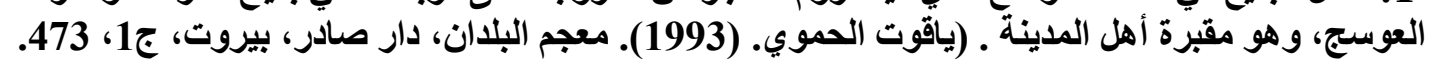

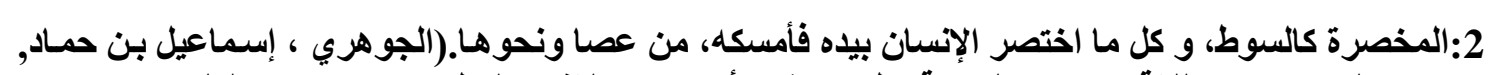

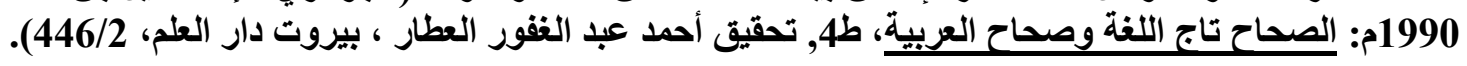


ثالثأ: بين أنهما آيتان لا يتأثران بموت أحد أو حياته و إنما لهما سنن كونيه فهي تجري في

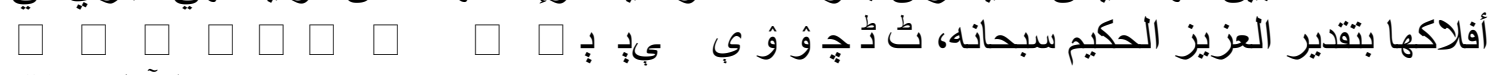

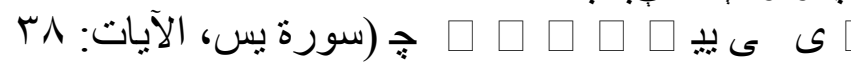

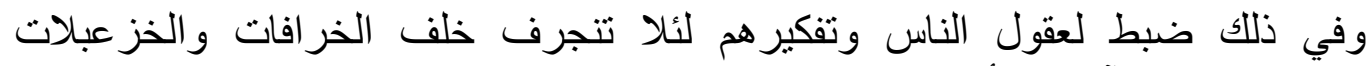

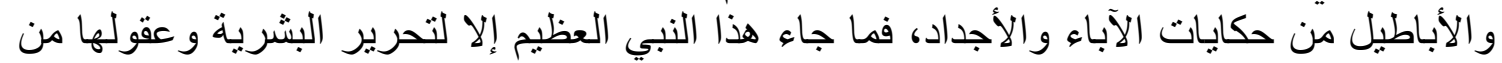

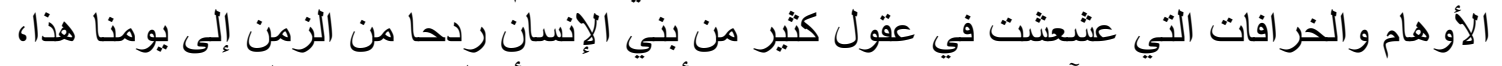

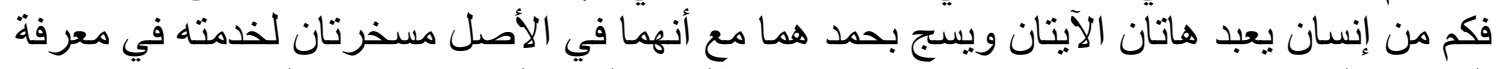

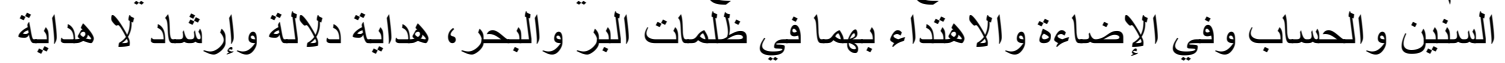

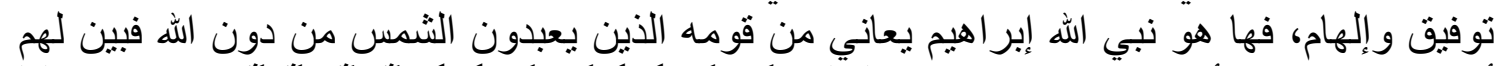

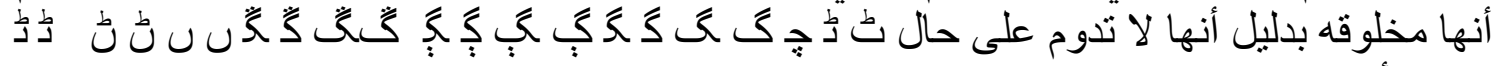
هُ جه الأنعام:78

فانظر إلى روعة استغلال هذا الحدث الكوني المهيب من قبل أستاذ الدنيا محمد بن عبدا لها

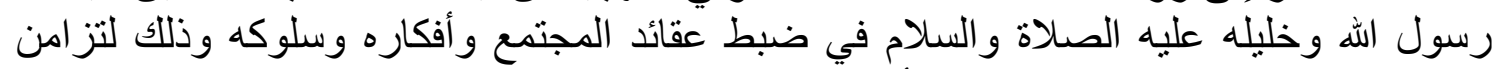

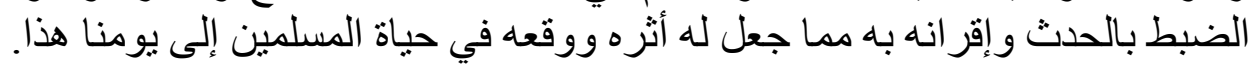
ويكون الاستغلال التربوي للحدث على صور ثناث كما يقول خليل الحدري:

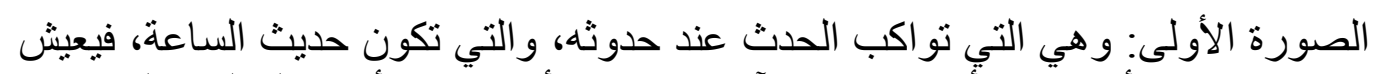

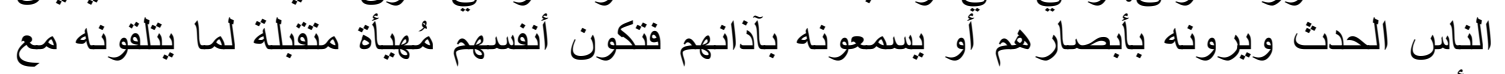
الأحداث من توجيه تربوي.

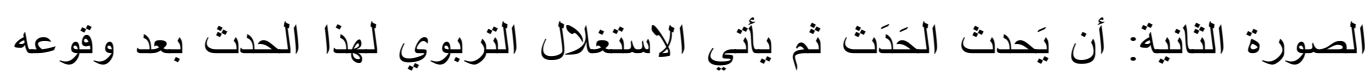

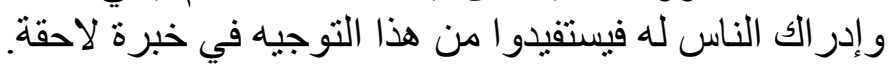

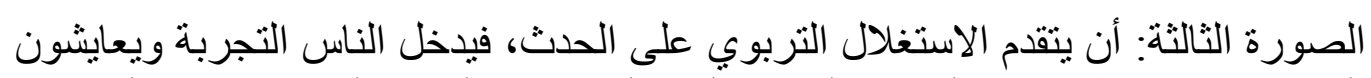

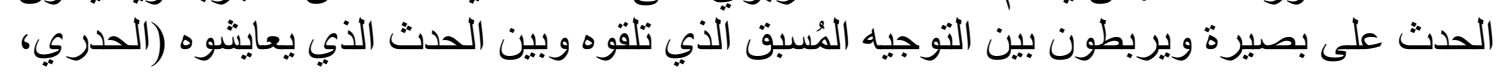
1418 148 هـ، 285 عاى

$$
\text { و استخدام هذا الأسلوب يتطلب من المعلم ما يلي (معلم، 1429 هـ، 190): }
$$

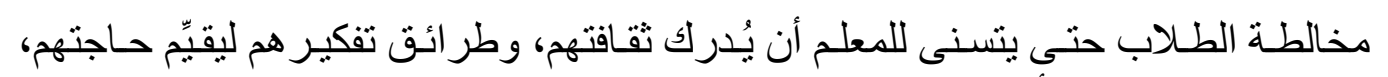

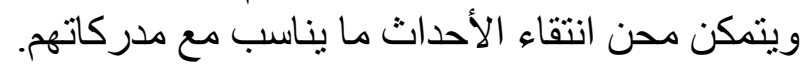

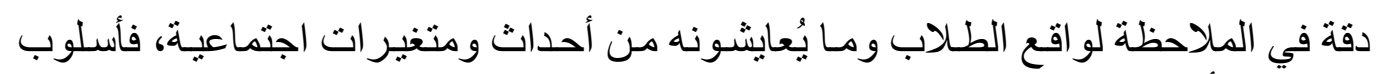

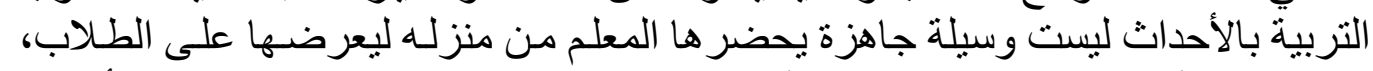

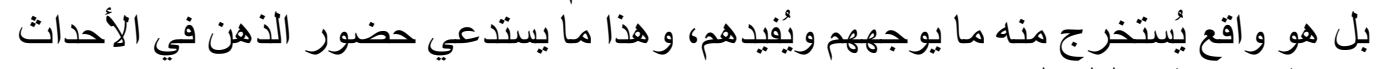

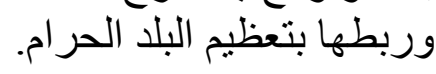

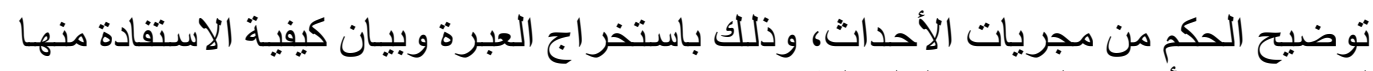
لتوظيفها في أرض الو اقع وسلوك الطناب.

$$
\text { 9. - أسلوب الترغيب والترهيب: }
$$

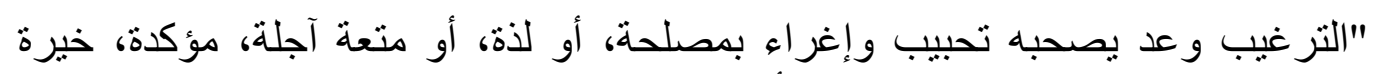

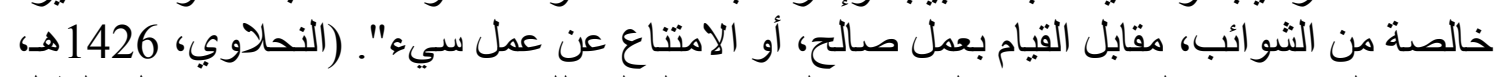
287) وليس معنى الترهيب هو التخويف المفزع و المقلق للنفس، وإنما هو تنكيل النكير عمل الطفل 
بعقوبة المخالفة ويعتبر التر غيب و التر هيب من الأساليب الناجمة في إصلاح الطفل وتأديبه ذلك لأن النفس البشرية تميل إلى الترغيب في العمل وثمرته وتخاف من التحذير من فعل الخطأ ونتائجها

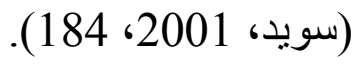

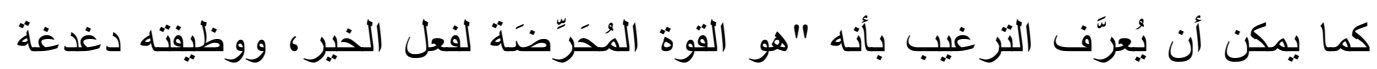

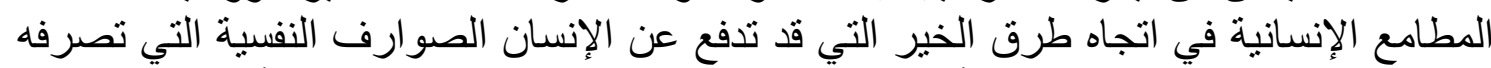

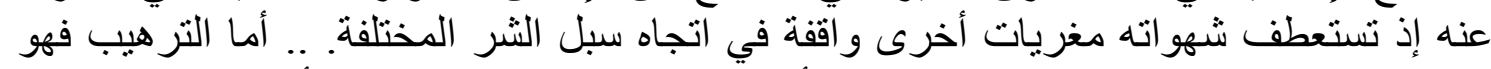

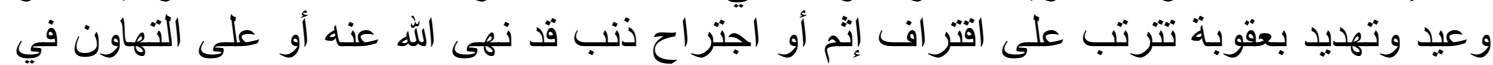

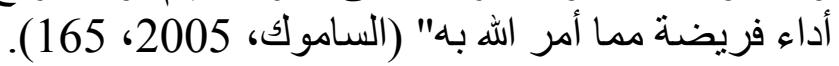

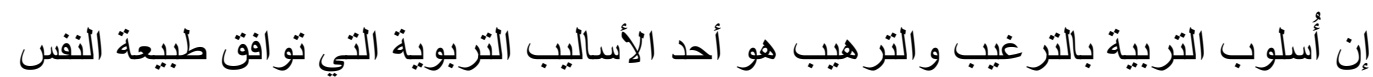

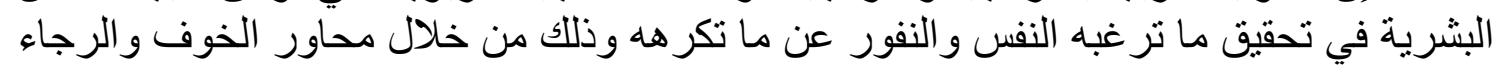

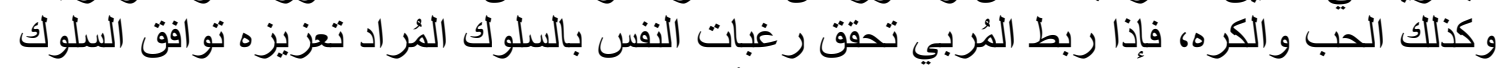

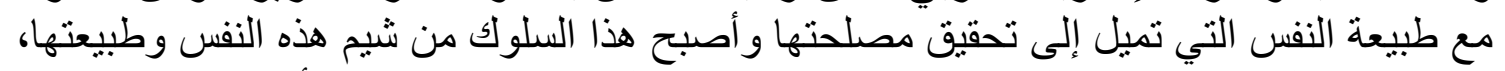

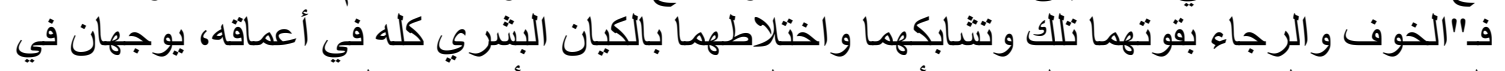

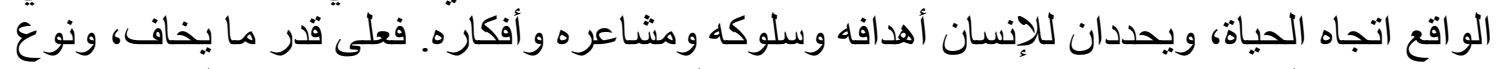

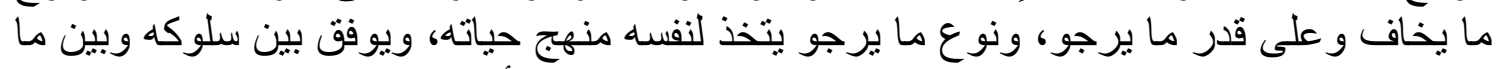
يرجو وما يخاف " (قطب، 2011، 127، 128)، فيكون بذللك التأثير على النفس البشرية باستخدام أسلوب الترغيب والترهيب شريطة أن يكون استخدام هذا الأسلوب بمقدار متوازن لا يطغى فيه

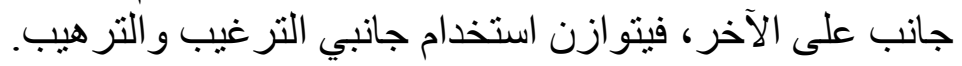

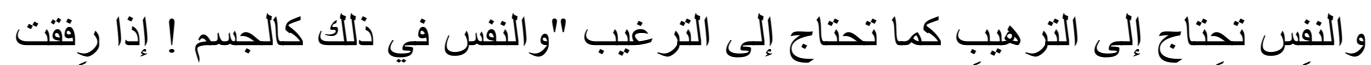

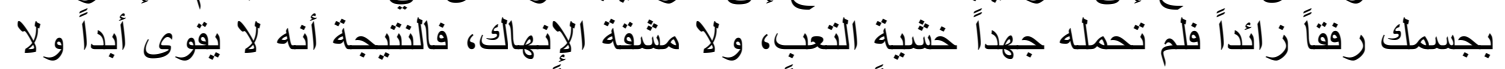

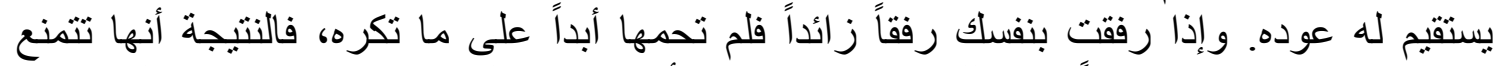

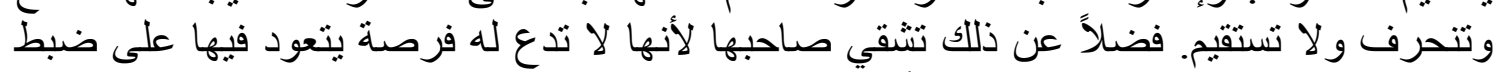

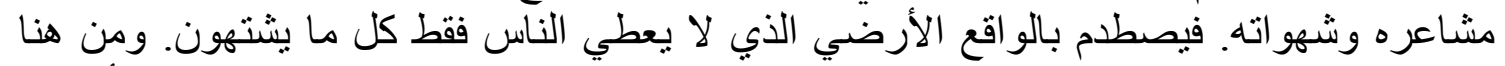

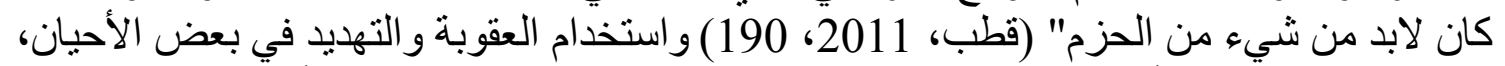

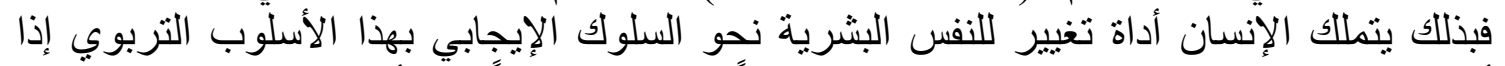

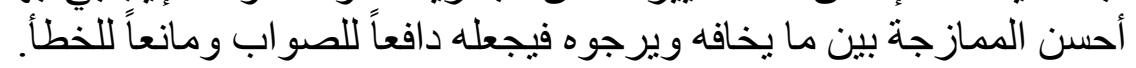

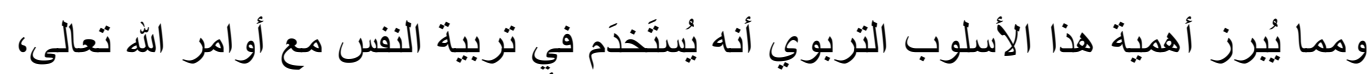

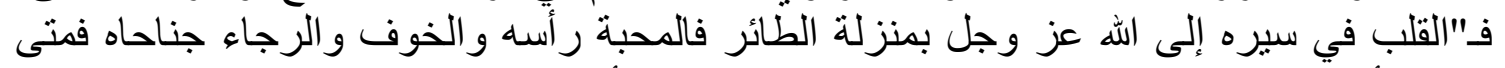

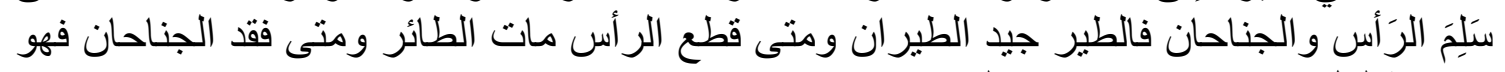

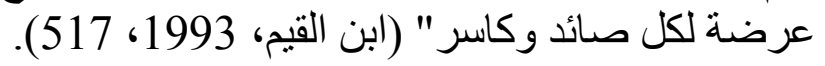

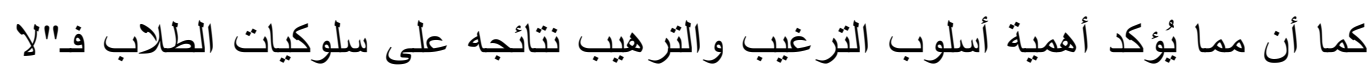

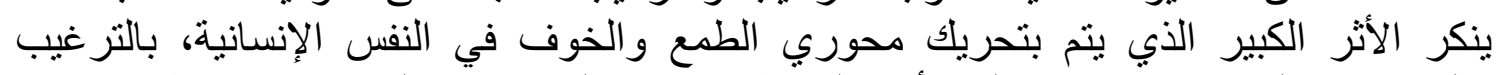

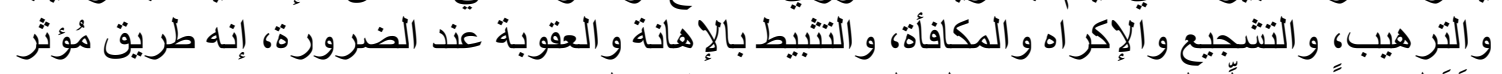

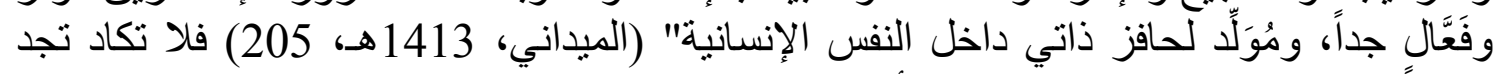

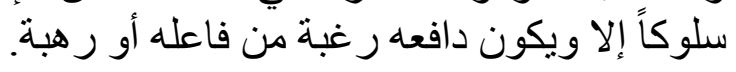
وقد أثر عن النبـي م أنه كان بيتخدمه في حالات كثيرة منها على سبيل المثال الترغيب في بر الو الدين و التر هيب من عقد التب مقهما.

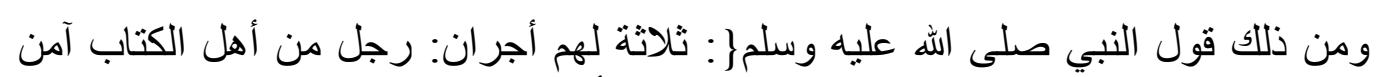

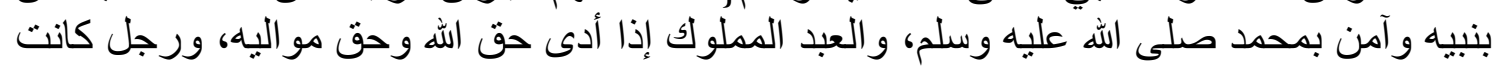


عنده أمة يطؤها فأدبها فأحسن تأديبها، و علمها فأحسن تعليمها، ثم أعتقها فتزوجها فله أجران

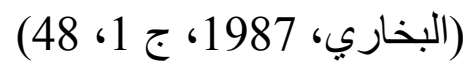

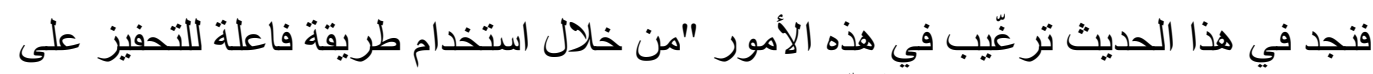

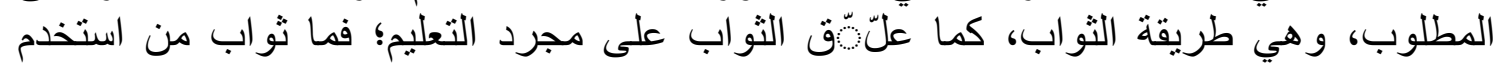

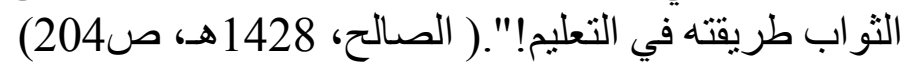

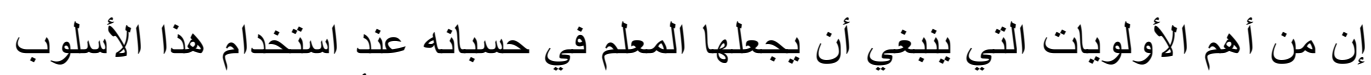

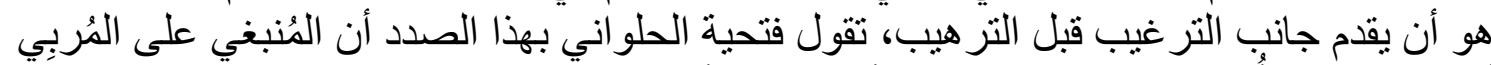

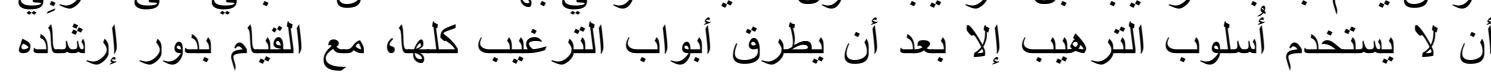

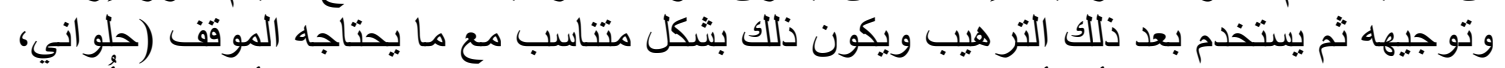

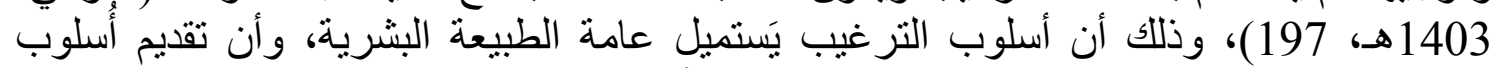

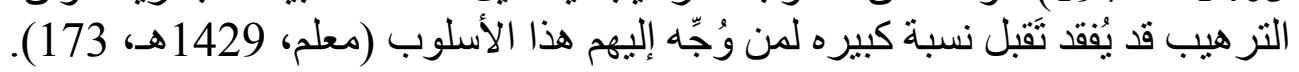

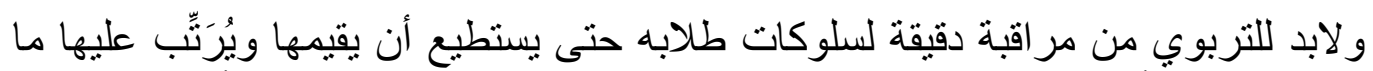

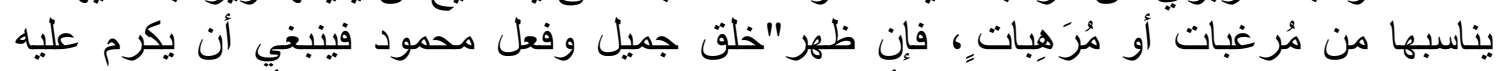

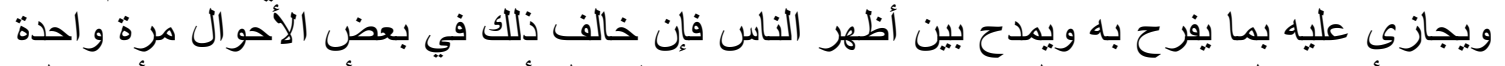

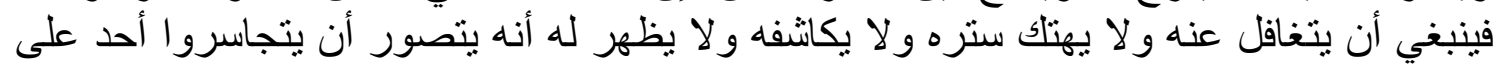

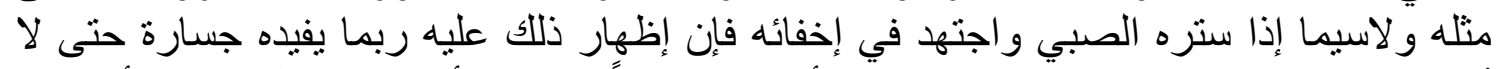

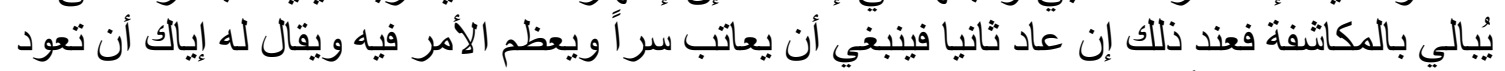

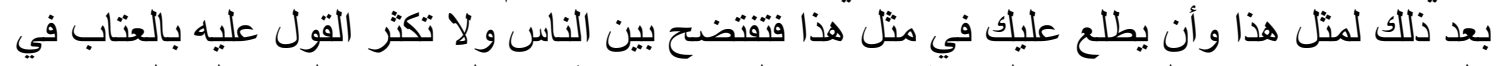

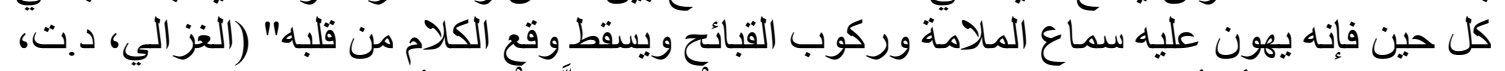

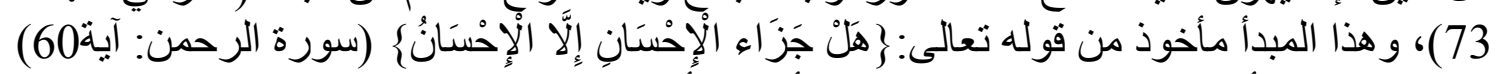

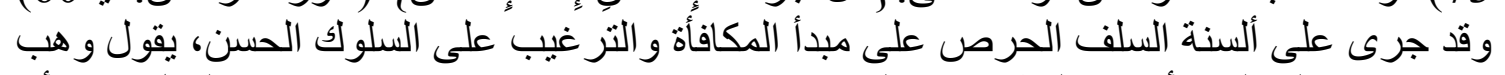

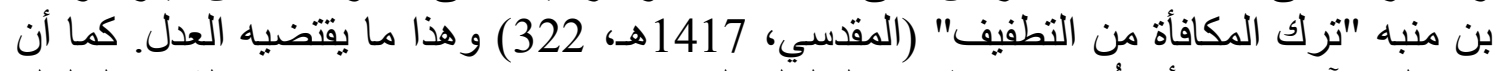

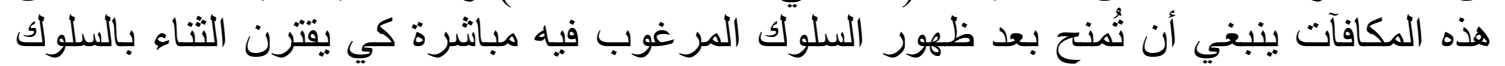

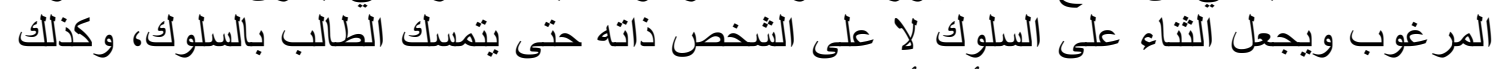

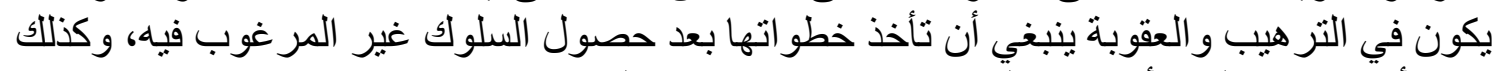

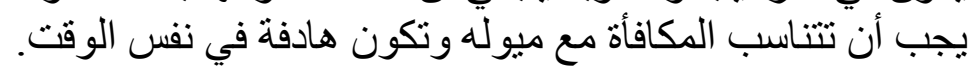

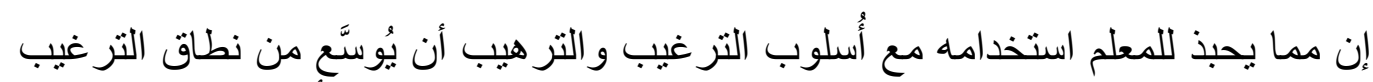

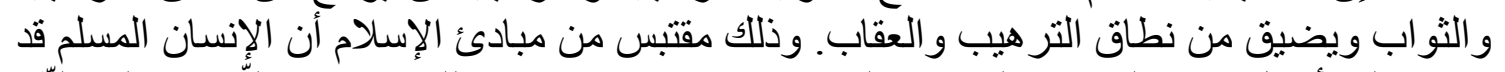

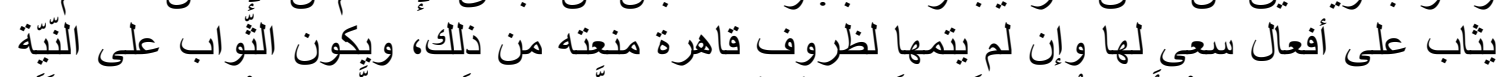

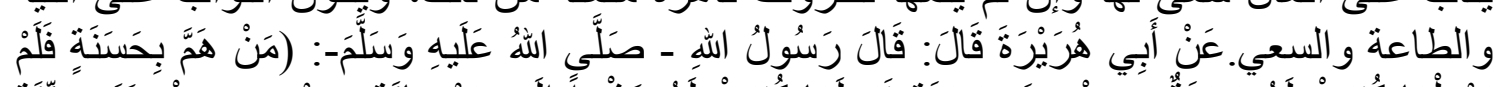

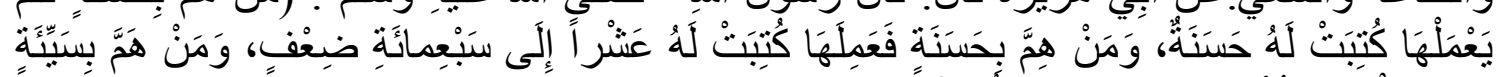

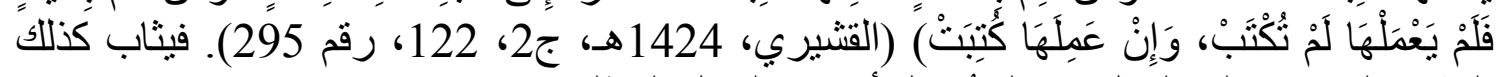

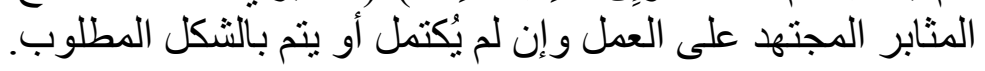

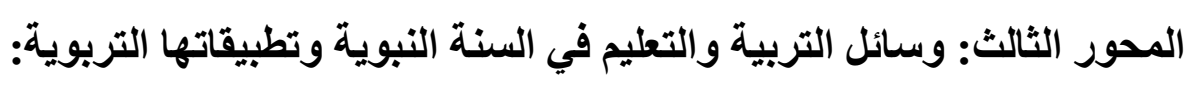

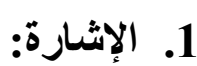
الإنشارة وسيلة تعليمية لتوضيح الفكرة، كما أن التعليم بها أبلغ. ورسول الله صلى اللهابل الله عليه

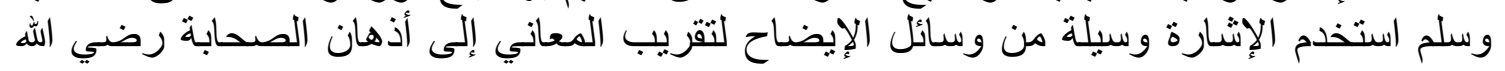


وقد استخدم رسول الله - صلى الله عليه وسلم - الإشارة ولغة الجسد في توضيح الأفكار

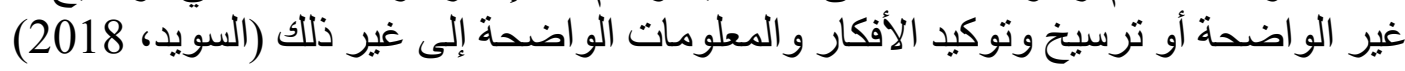

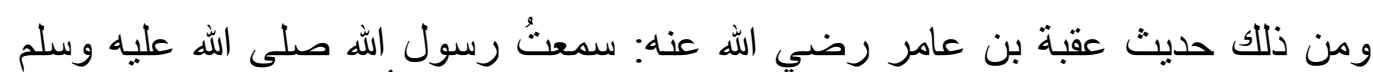

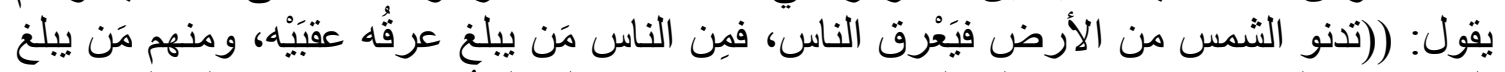

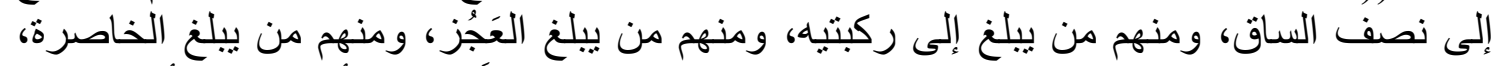

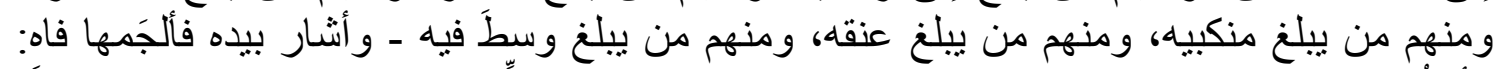

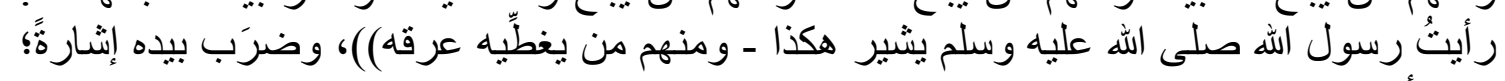
رواه أحمد.

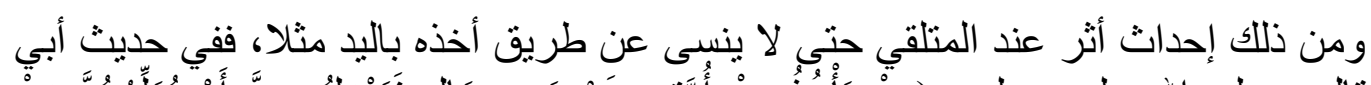

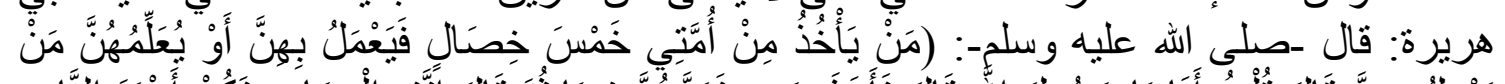

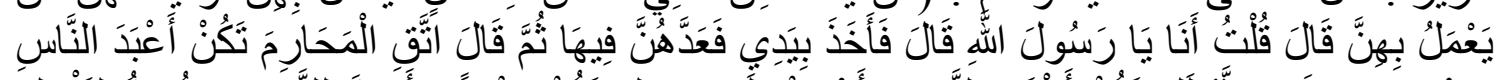

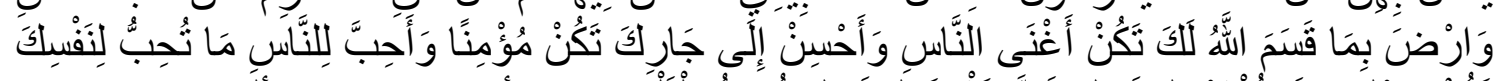

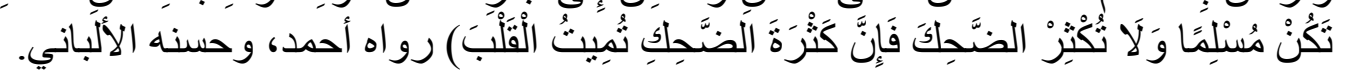

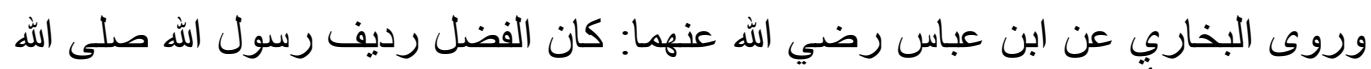

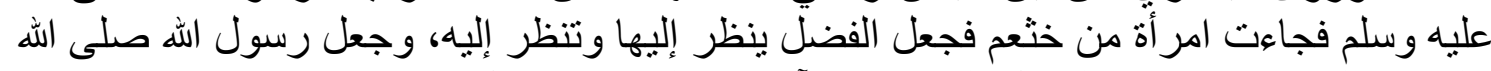

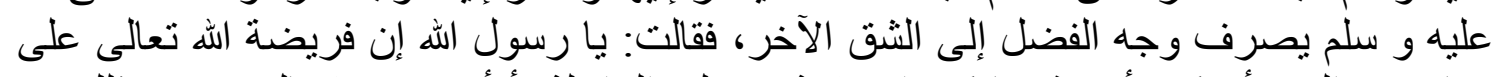

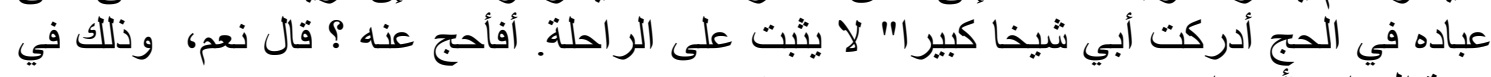

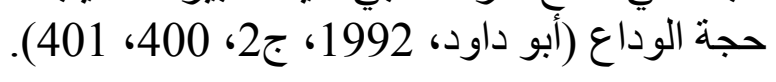

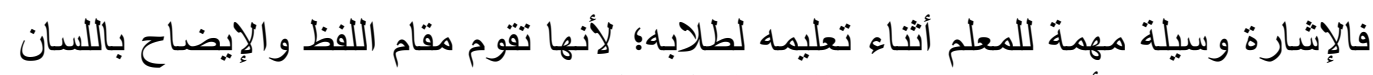

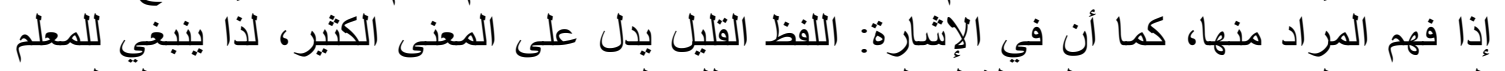

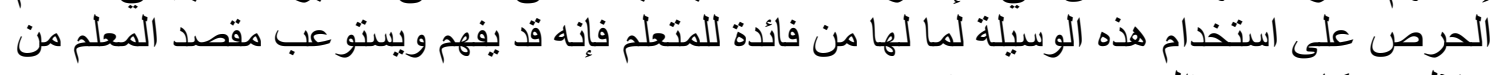

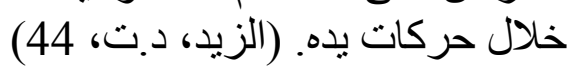

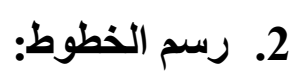

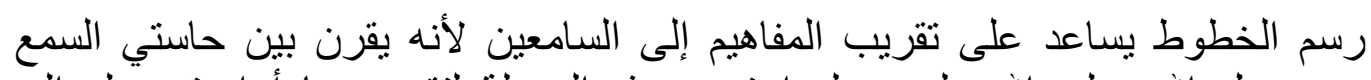

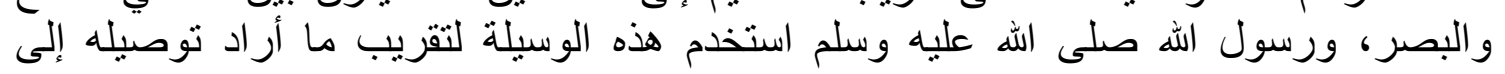

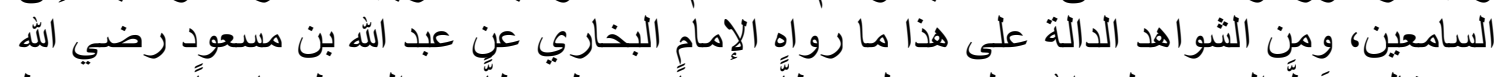

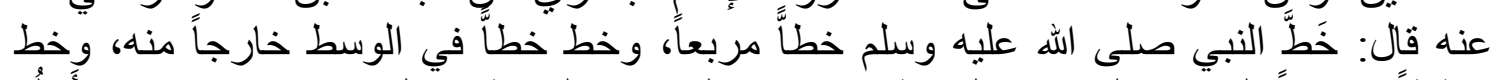

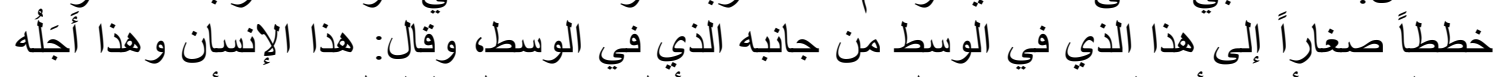

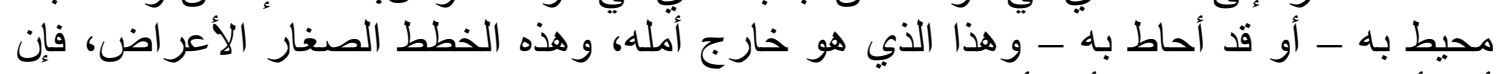

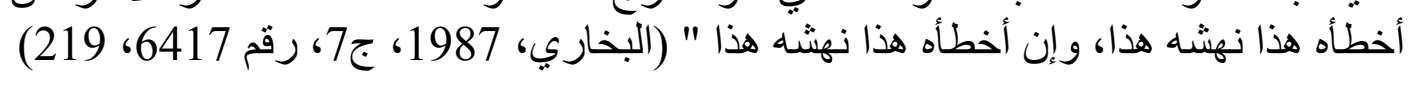
وقد مثل ابن حجر رحمه الله في كتابه القتح هذه الخطوط على النحو الآتي:
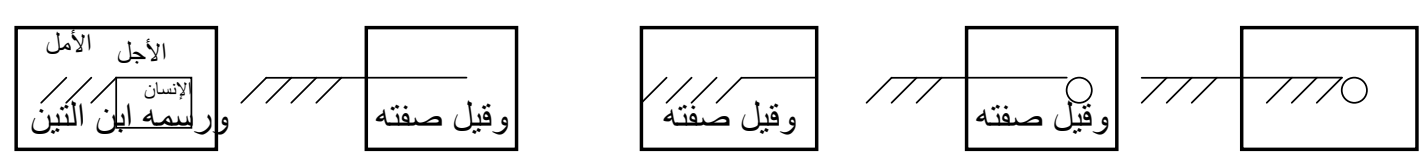

وعن ابن مسعود ح أيضاً فيقول:خط رسول الله م خطاً بيده ثم قال:(هذا سبيل الله مستقبما). قال ثم خط عن يمينه وشماله، ثم قال: (هذه السبل، وليس منها سبيل إلا عليه شيطان يدعو إليه، ثم 


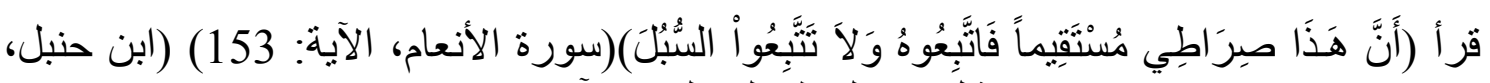
1429هـ، ج1، 435). ويمكن تمثيل هذا الخط على النحِ النحو الآتي:

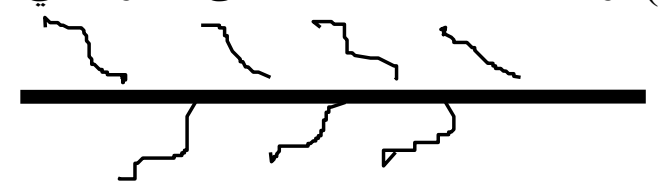

و هذه الخطوط التي وضح بها رسول الله م بعض قضايا العقيدة أمور سهلة ولكنها ذات

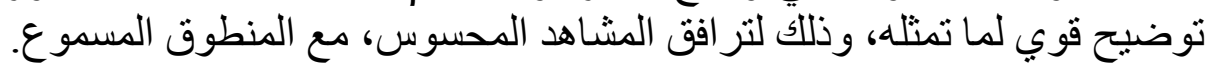

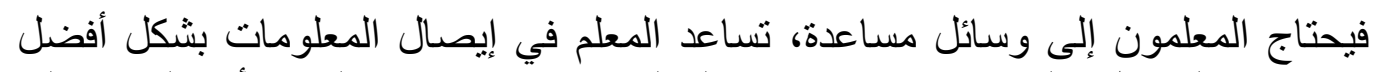

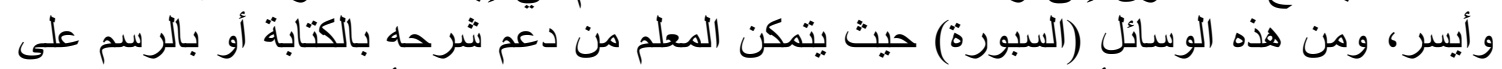

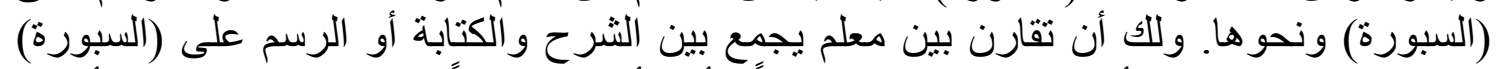

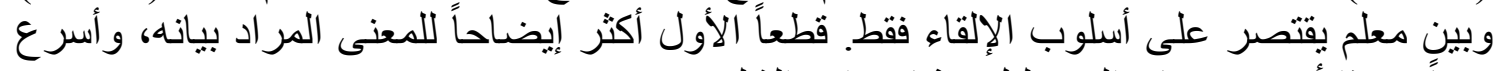

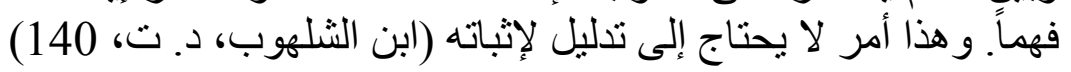
3. - استخدام الأدوات المادية:

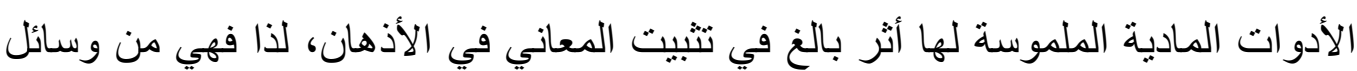

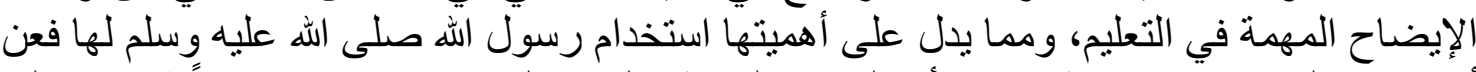

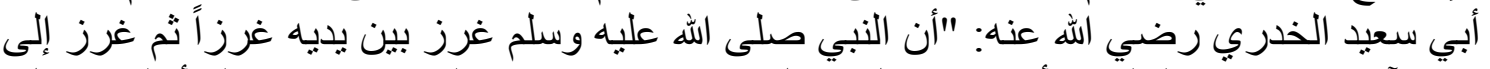

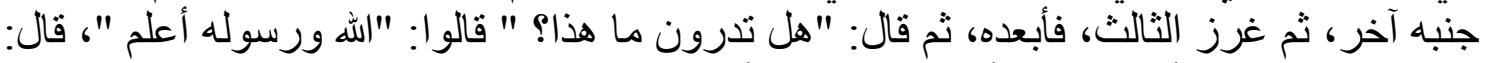

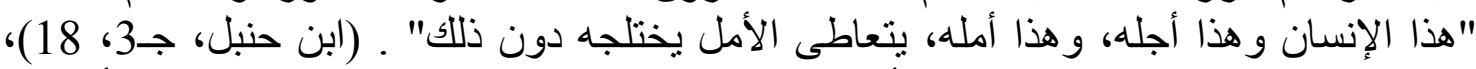

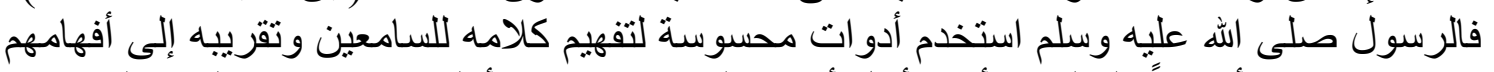

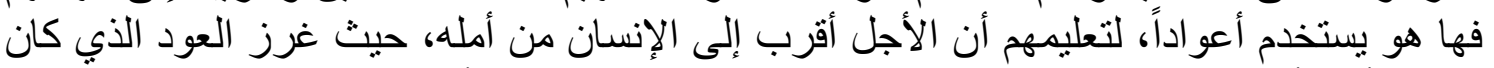

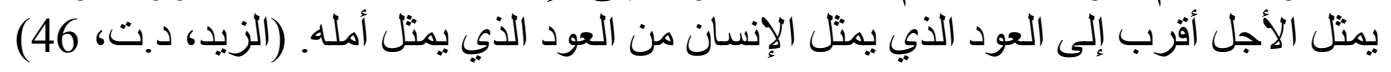

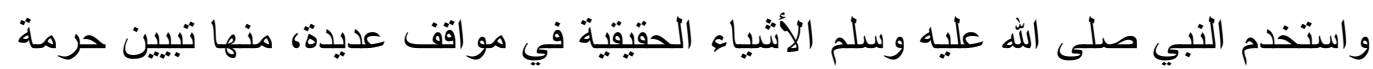

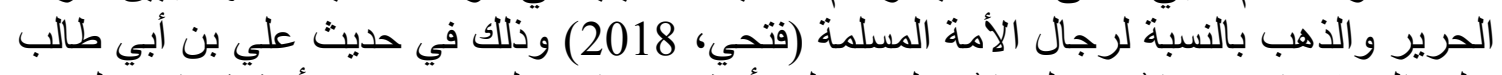

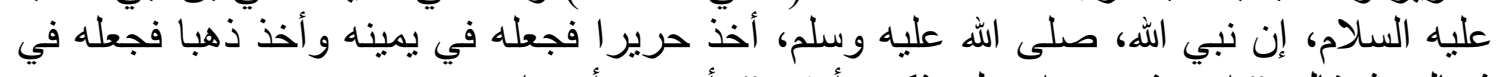

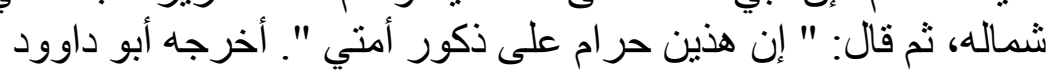

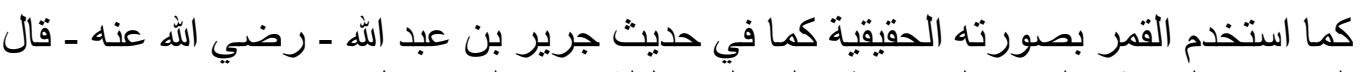

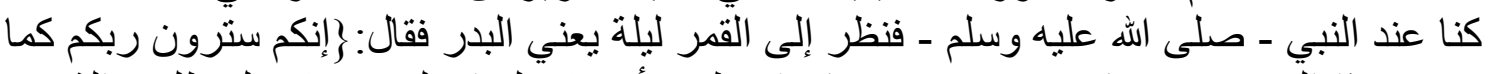

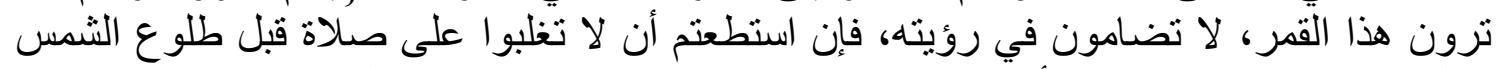

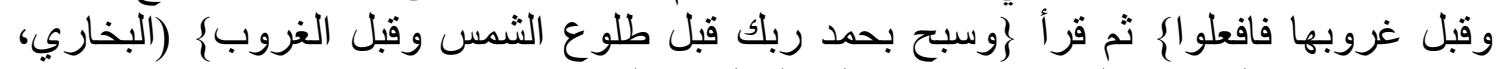
1987، 554)، ليتصور السامع ما يكون عليه الحال في الجنة.

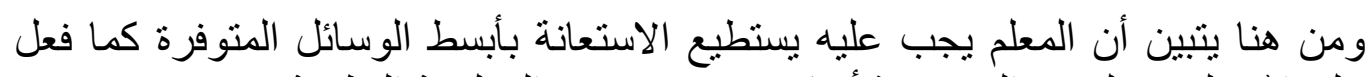

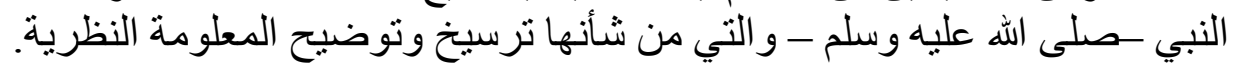

4. التعليم بالفعل والمشاهدة:

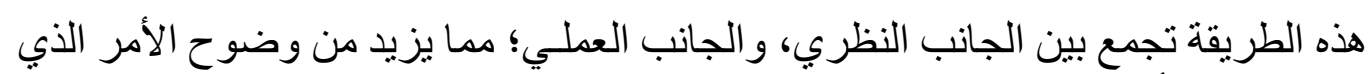

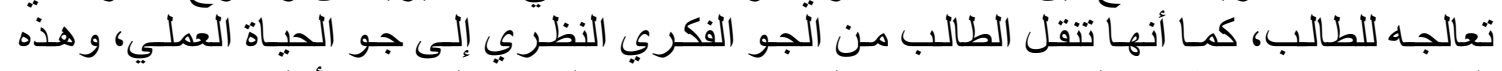

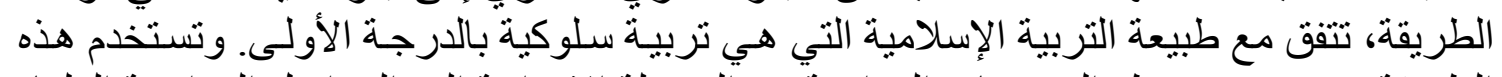
الطريقة في تدريس معظم المستويات الدراسية من ألمرحلة الابتدائية إلى المر احل الإلى الدراسية العليا، 
و تعتمد هذه الطريقة على نشاط المعلم، أو من ينوب عنه، فقد يستعين المعلم ـ مثناً ـ بتلميذ، أو أكثر

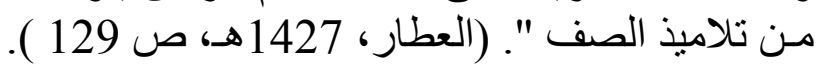

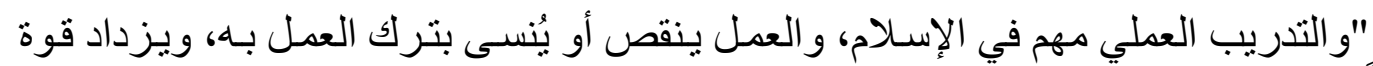

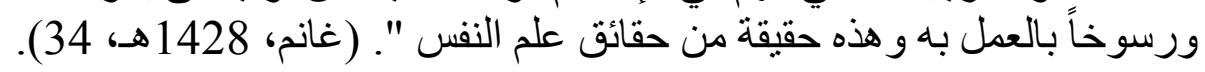

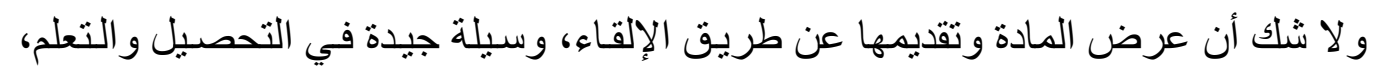

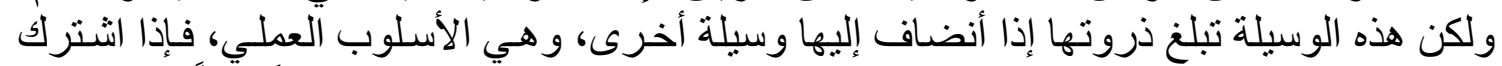

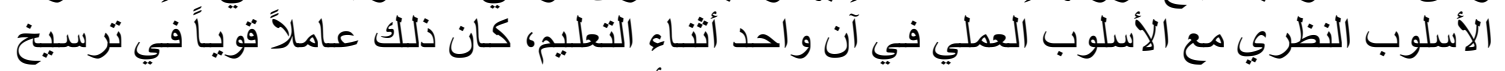

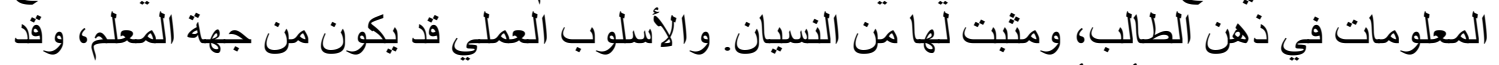
يكون من جهة المتعلم، أي أن الفعل قد يكون من المعلم، وقد يكون من المتعلم (ابن الثلهوب، دئ د.ت،

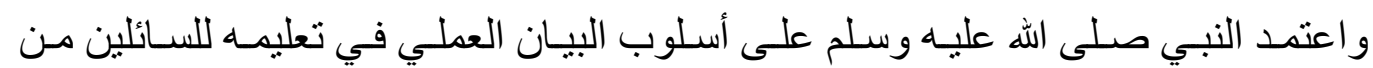

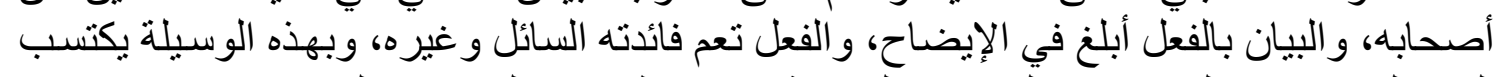

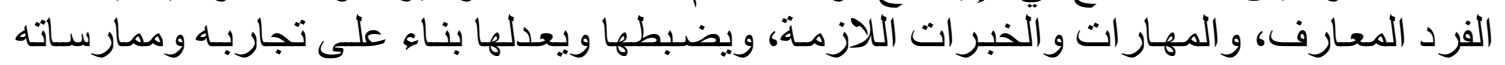

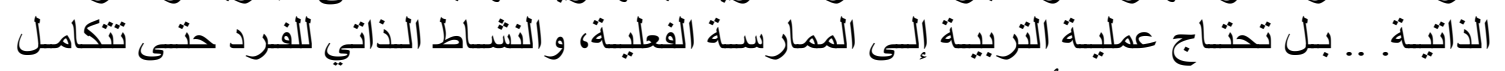

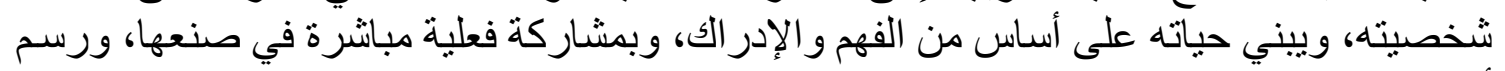

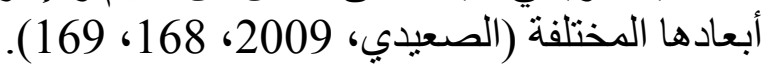

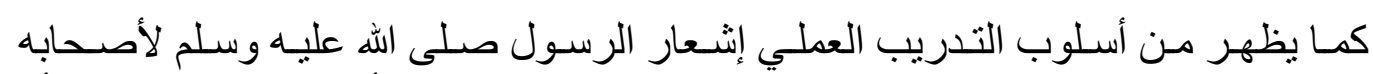

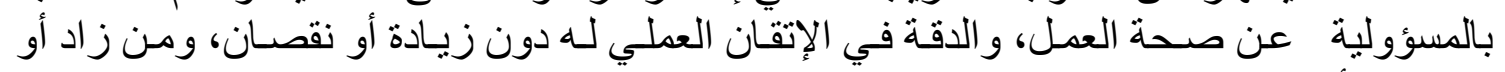

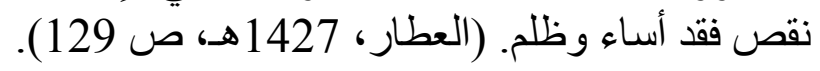

فلا يستوي أثر المعاني حين تربط بصور محسوسة، مع عرضها في صورة مجردة جافة.

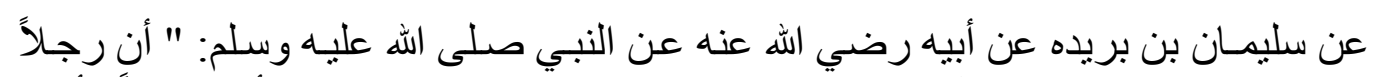

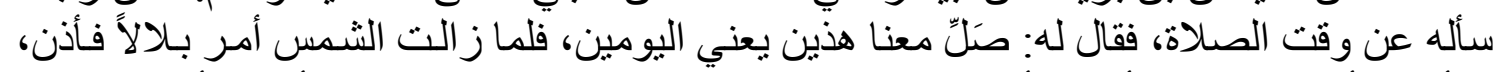

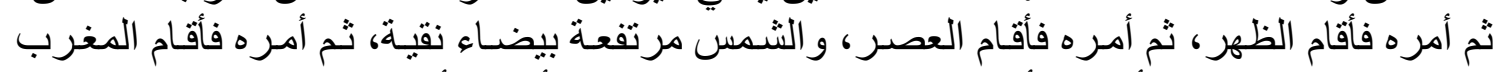

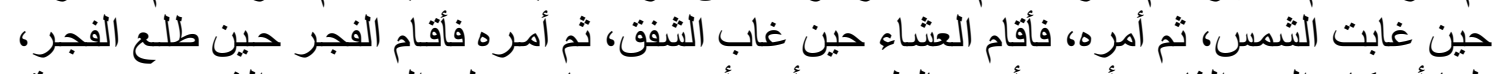

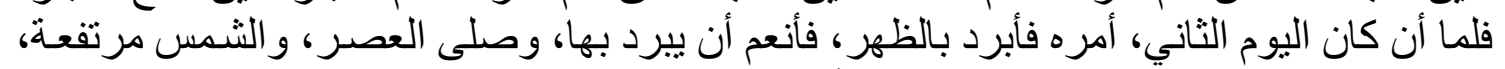

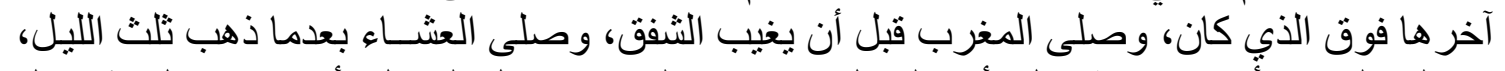

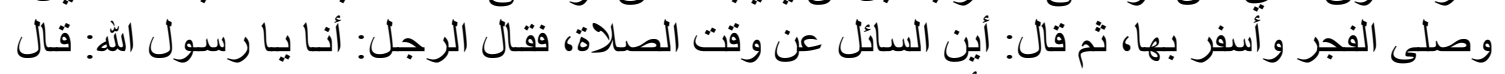

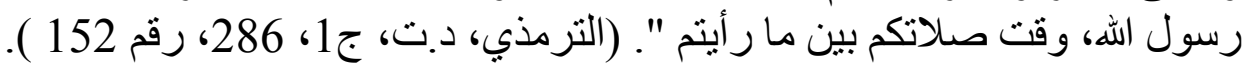

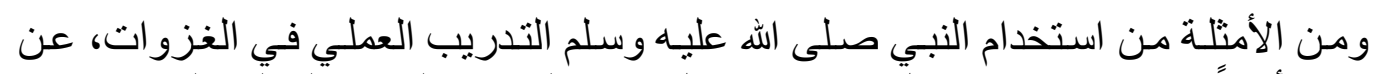

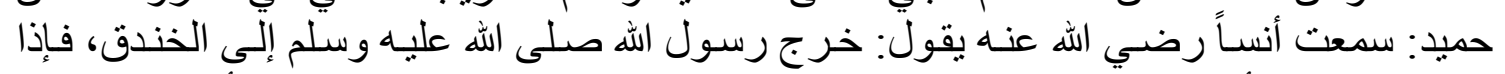

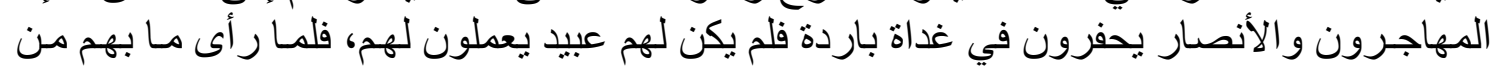

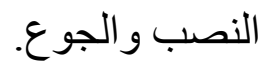

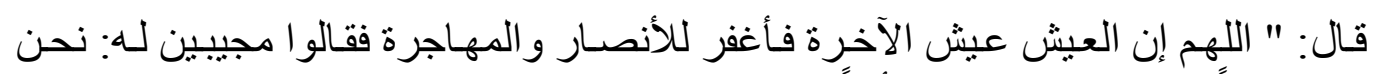

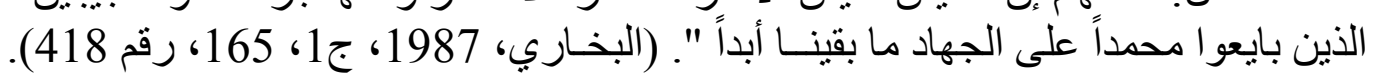

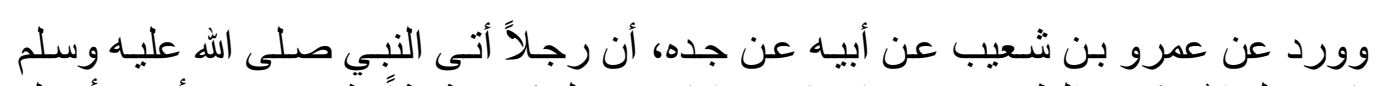

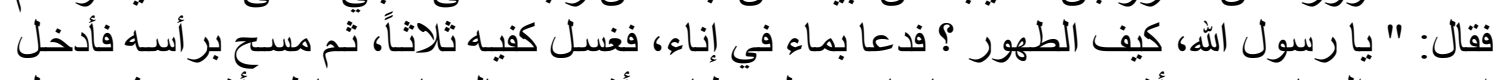

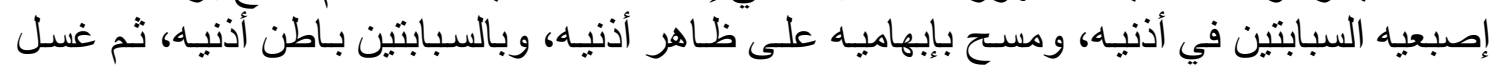




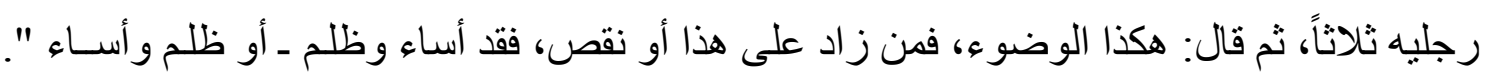

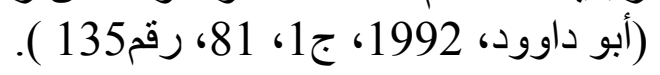

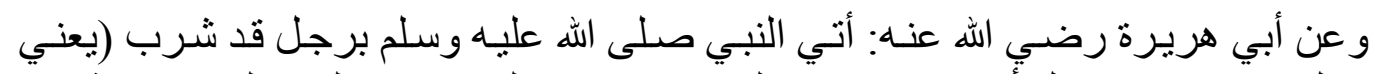

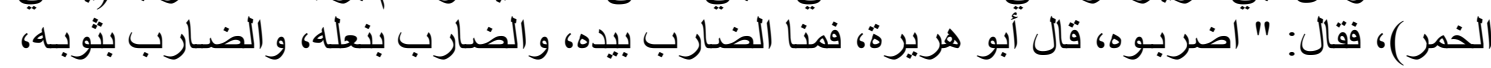

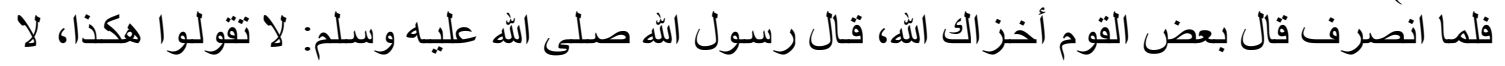

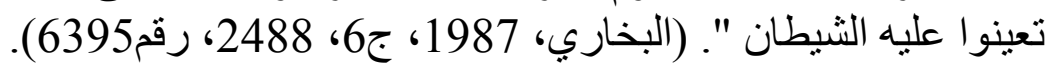

وفي هذا الحديث تدريب الرسول صلى الله عليه وسلم لأصحابه على كيفيـة تطبيق حد ركد

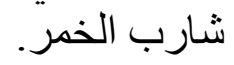

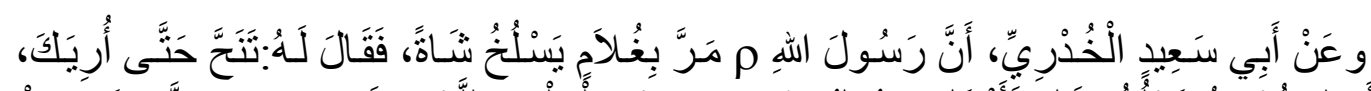

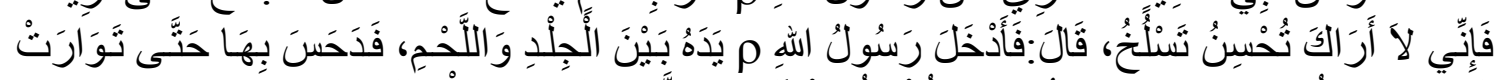

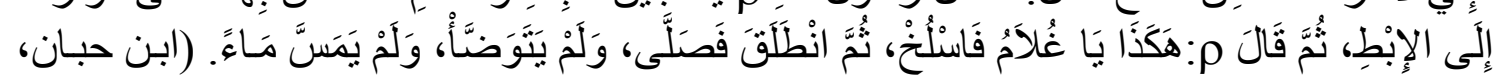

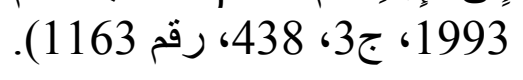

وسنة النبي -ـصلى الله عليه وسلم -ز اخرة بنماذج متنو عة استخدم فيها الرسول عليه السلام

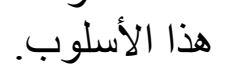

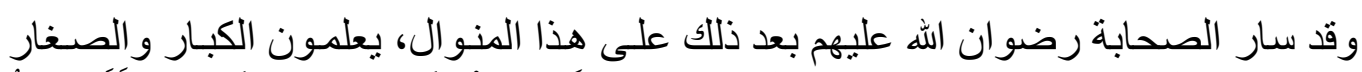

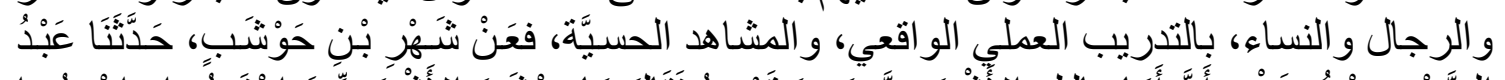

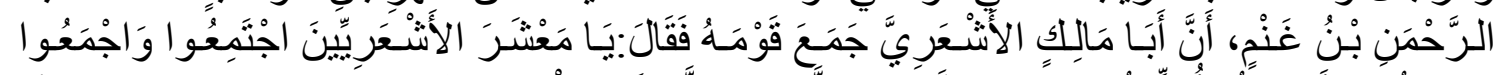

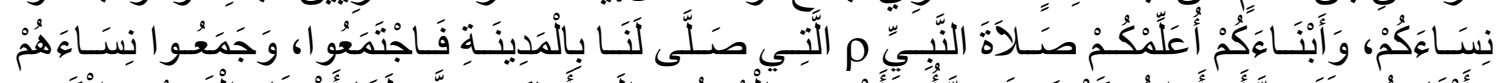

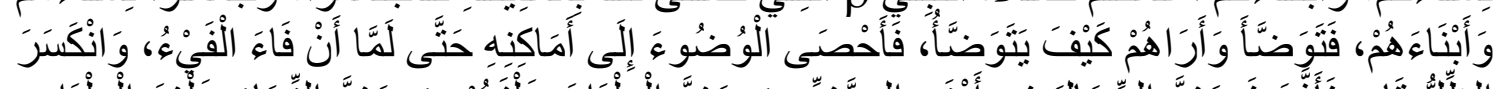

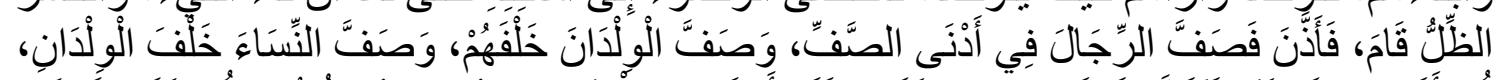

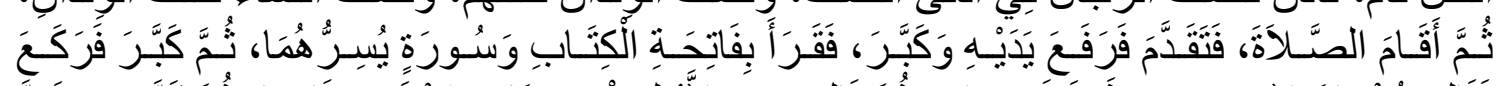

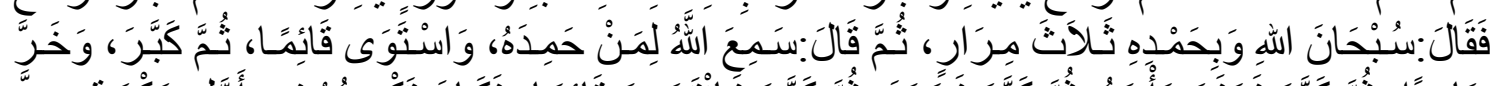

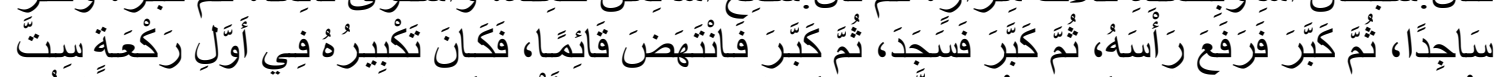

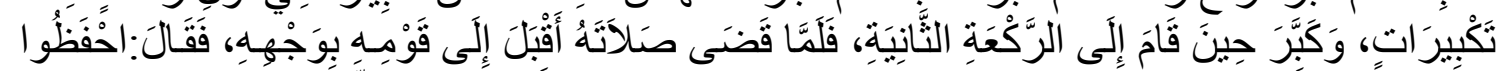

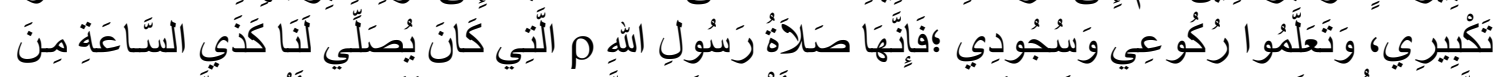

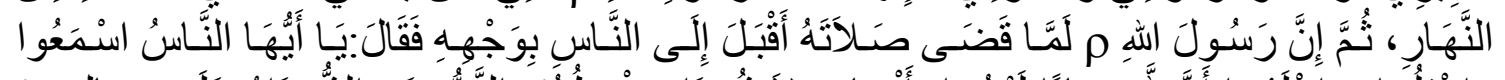

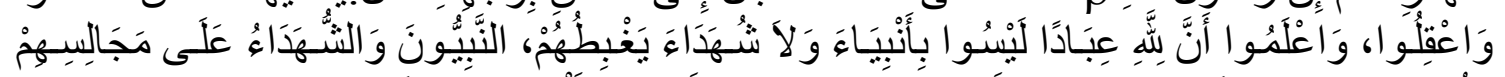

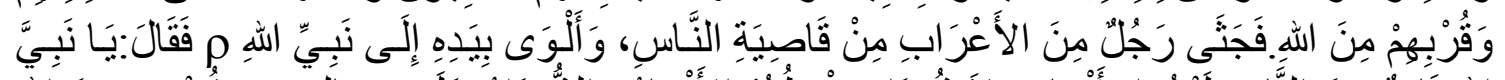

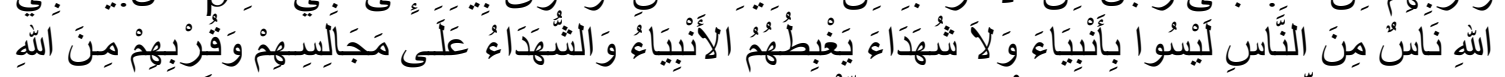

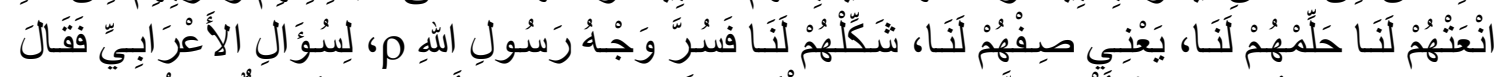

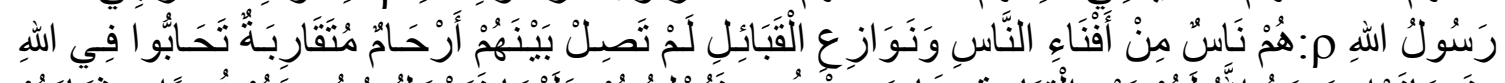

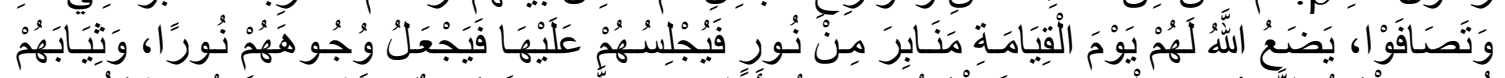

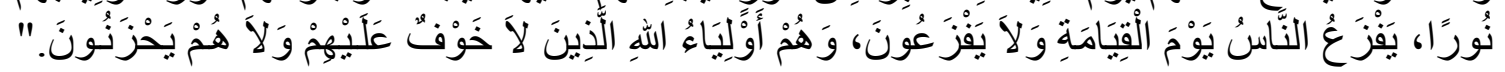

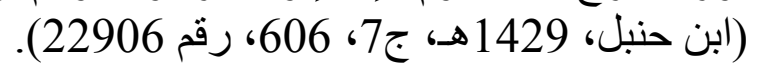

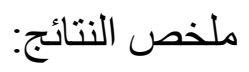

1. عرضت الدراسة للإطار الدفاهيمي لأساليب التربية والتعليم ووسائلها مبينة مفهوم كل منهما وأهميته. 


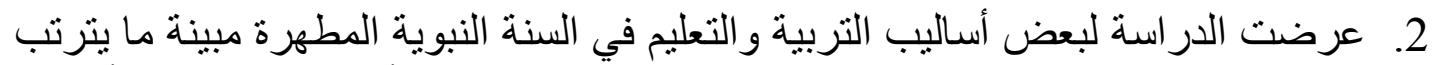

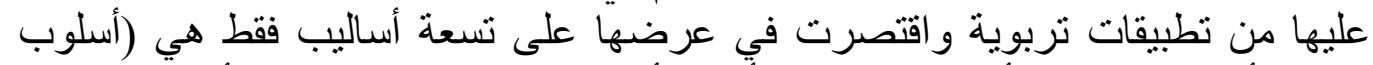

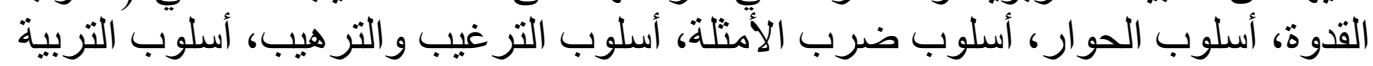

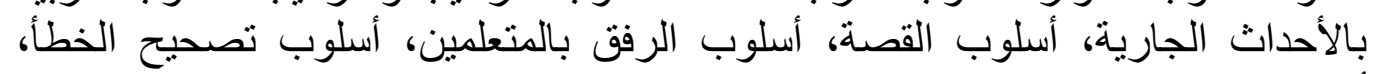

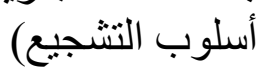

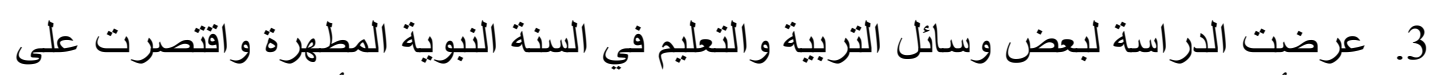

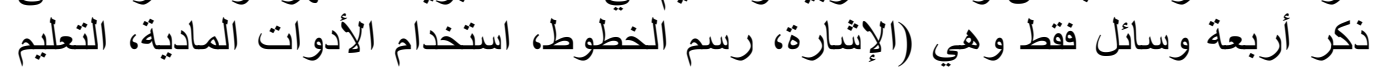

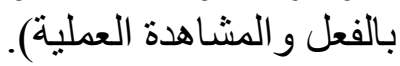

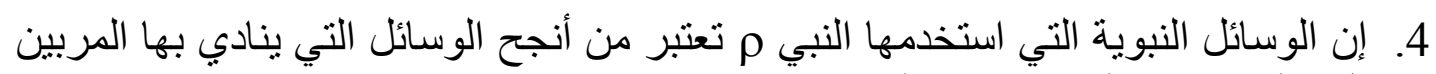

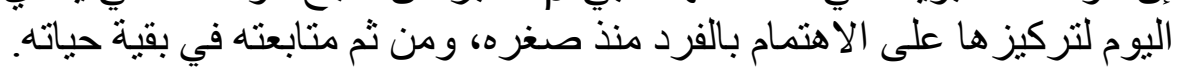

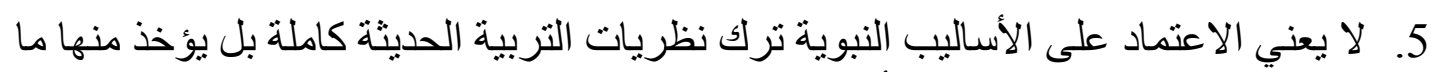

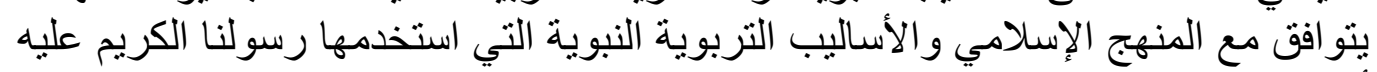

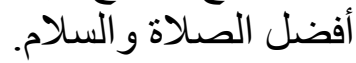

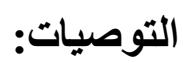

1. ضررورة الاستفادة من القرآن الكريم والسنة النبوية المطهرة في تطوير العندير العملية التعليمية

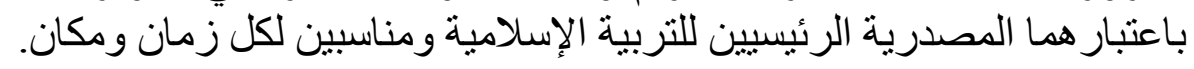

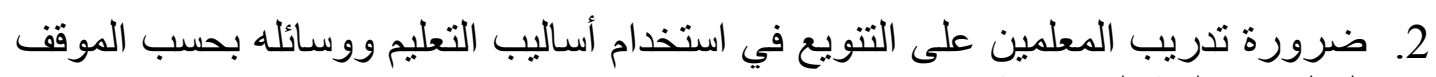
التعليمي و الفئة المستهدفة. 3. توفير المنطلبات المادية للتنويع في أساليب التعليم ووسائلة. 4. تهيئة المناخ التربوي الملائم لاستخدام الوسائل التعليمية. 5. ا ضرورة الاستفادة من المستحدثات التكنولوجية في تطوير أساليب ووسائل التعليه.

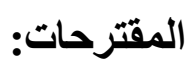

$$
\begin{aligned}
& \text { 1. أساليب التربية و التعليم في القرآن الكريم. }
\end{aligned}
$$

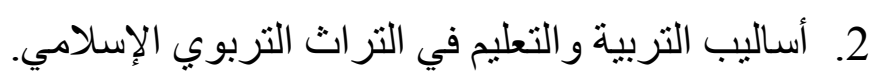

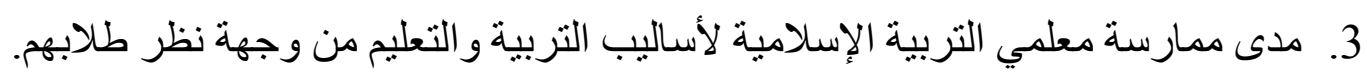

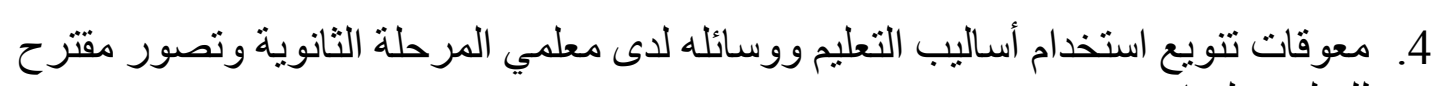
للتغلب عليها. 
إبر اهيم، صبحي طه رشيد. (1403هـ). التربية الإسلامية وأساليب تدريسها، دار الأرقم للكتب، ابن القيم، محمد بن أبي بكر شمس الدين. (1406هـ). الأمثال في القرآن، مكتبة الصحابة.

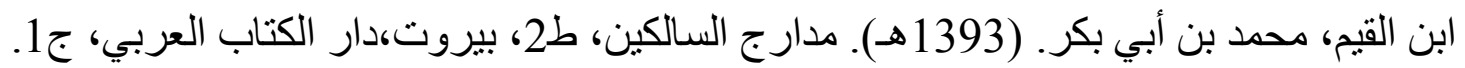

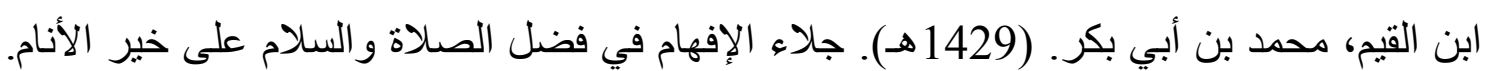
مكة المكرمة، دار عالم الفو ائد.

ابن القيم، محمد بن أبي بكر. (1971). اركة الحفة المودود بأحكام المولود، تحقيق: عبد القادر الأرناؤوط، مكتبة دار البيان، دمشق.

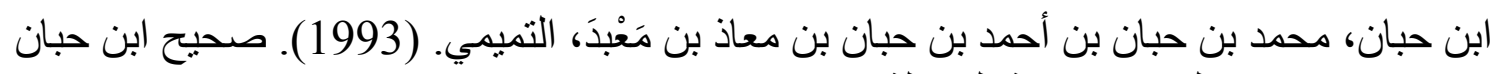

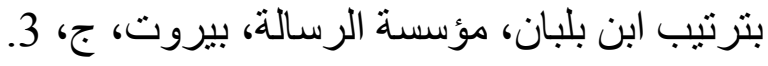

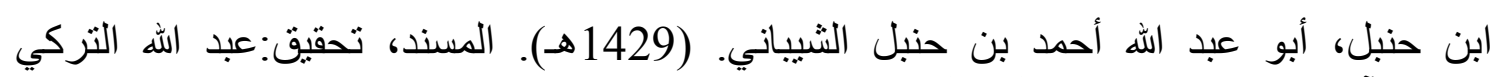
وآخرون، ط2، مؤسسة الرسالة، بيروت، لبنان. 
ابن رجب، عبد الرحمن بن أحمد. (1408 هـ). جامع العلوم والحكم. بيروت، دار المعرفة.

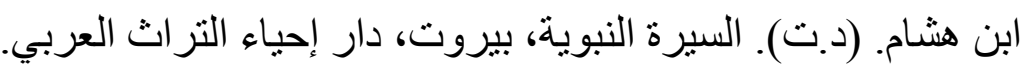
أبو داود، سليمان الأشعث. (1992). سنن أبي داود، بيروت، دار الجيل. أبو دف، محمود. (2002). بعض الأساليب التربوية المستنبطة من خلال السنة النبوية رسالة الإدية ماجستير غير منشورة، جامعة الأز هر، مصر.

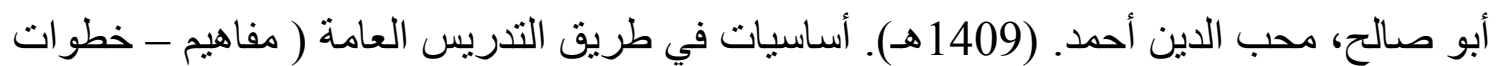

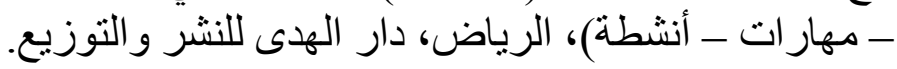
أبو طور، عبد المعطي محمود. (2001). معالم تربية المحدثين في القرن الثالث، ط1, مصر ، دار الثرار

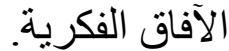

أبو غُدَّة، عبد الفتاح. (2003). الرسولة المعلم وأساليبه في التعليم، ط3، مكتبة المطبوعات

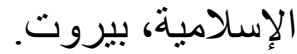

آل سلمان، مشهور بن حسن. (1415هـ). المروءة وخوارمها، الخبر، السعودية، دار العفان للنشر

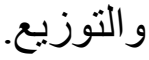

بخش، أميرة بنت طه بن عبد اله. (1428 هـ). مفهوم الأمن الفكري في الإسلام وتطبيقاته التربوية رسالة ماجستير، جامعة أم القرى، كلية التربية، مكة المكرمة.

البشري، محمد بن شاكر. (2006). نحو تربية إسلامية راشدة من الطفولة حتى البلوغ، صدر عن التربه

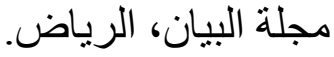

بكار، عبد الكريم. (1428هـ). تأسيس عقلية الطفل، جدة : مركز الراية للتنمية الفكرية.

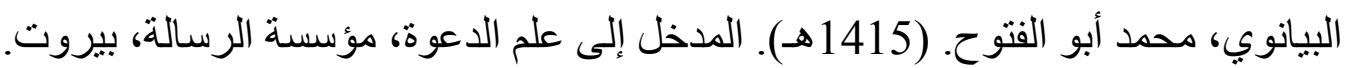

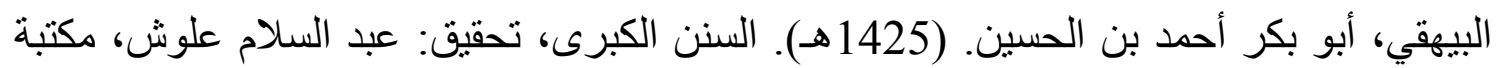

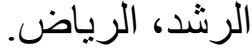

الترمذي، أبو عيسى محمد بن عيسى. ( د.ت). الجامع الصحيح، وهو سنن الترمذي، تحقيق: أحمد محمد شاكر، دار الحديث، القاهرة.

جان، محمد صالح بن علي. (1998). المرشد النفيس إلى أسلمة طرق التدريس، للآباء و الدعاة

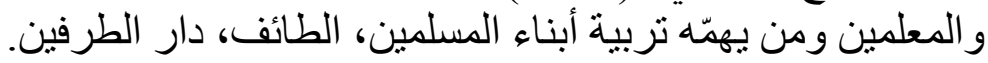
الجندي، أنور. (1975). التربية وبناء الأجيال في ضوء الإسلام. دار الكتاب اللبناني للطباعة و النشر والتوزيع. الجوهري، إسماعيل بن حماد. (1990). الصحاح تاج اللغة وصحاح العربية، ط4، تحقيق أحمد عبد الغفور العطار، بيروت دار العلم. الحازمي، خالد بن حامد. (2002). المشكلات التربوية الأسرية والأساليب العلاجية، دار عالم المارئ الكتب للطباعة و النشر و التوزيع، الرياض.

حافظ، حبيبة بنت مصطفى بن علي. (2007). استخدام المعلم أساليب التربية النبوية في تعديل

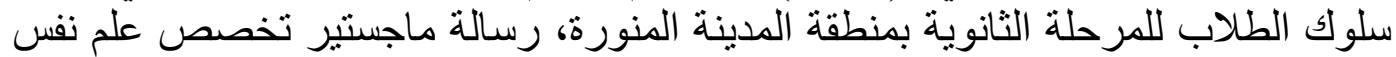
تربوي، الجامعة الوطنية، الجمهورية اليمنية. 
الحدري، خليل بن عبد الله. (1318هـ). التربية الوقائية في الإسلام ومدى استفادة المدرسة الثانوية منها، رسالة ماجستير منشورة، مكة المكرمة، جامعة التهة أم القرى.

الحلو اني، فتحية عمر. (1403 هـ). در اسة ناقدة لأساليب التربية المعاصرة في ضوء الإسلام، جدة : تهامة.

الحموي، ياقوت. (1993). معجم البلدان، دار صسادر، بيروت، ج1.

حيدر ، حازم سعيد. (2010). المقومات الثخصية لمعلم القرآن، مجمع الملك فهذ لطباعة المصحف الثريف.

الدويش، محمد بن عبد الله.(2000). المُدَرَسُ ومهارات التوجيه، ط4، مدار الوطن للنشر، الرياض.

الدويش، محمد. (1437هـ). التربية النبوية، مركز البيان للبحوث والدر اسات. الديب، إبر اهيم. (1427هـ). أسس ومهار ات بناء القيم التربوية وتطبيقاتها في العملية التعليمية، المنصورة : مؤسسة أم القرى اللترجمة و التوزيع.

الديلمي، عبد الوهاب بن لطف. (1998). معالم الدعوة في قصص القرآن الكريم، ج1، مكتبة الإرشاد.

رضوان، أبو الفتوح، وآخرون. (1978). المدرس في المدرسة والمجتمع ،القاهرة، مكتبة الأنجلو. رمضان، رمضان محمد (1990). أثر تفاعل أسلوب تعلم المعلّم والأسلوب المعرفي وأسلوب التعلم لدى المتعلم على التحصيل الدراسي، رسانئ رسالة دكتوراه (غير منشورة) كلية التربية بينها، جامعة الزقازيق.

الزيد، حصة بنت عبد الكريم. (د.ت). أهمية دراسة السيرة النبوية للمعلمين، مركز الملك فهر

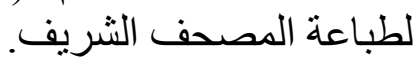

الساموك، سعدون. (2005). الأساليب التعليمية للتربية الإسلامية، عمَّان، دار وائل للنشر و التوزيع.

السقاف، عمرو طه. (1428هـ). فقه الدعوة إلى الله من خلال كتاب الأدب المفرد للإمام البخاري،

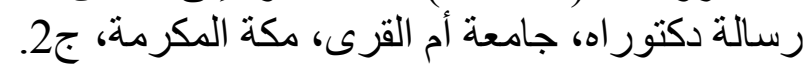

سلامة، سالم أحمد. (2001). أساليب النبي صلى الله عليه وسلم في تصحيح الخطأ عند الصحابة رضوان الله عليهم). مجلة البحوث و الدر اسات التربوية الفلسطينية، العدد 6، صل صل 1 - 40). السويد، سليمان بن أحمد. (2018). مقال لغة الجسد في التعليم النبوي، رابط الموضوع: http://www.alukah.net/social/0/95749/\#ixzz4NALBfNGC سويد، محمد نور بن عبد الحفيظ. (2001). التربية النبوية للطفل، دار ابن كثير، دمثق. الشعر اوي، محمد منولي. (1997).تفسير الشعر اوي الخاوطر، مطابع أخبار اليوم. الثلهوب، فؤاد بن عبد العزيز. (د.ت). المعلم الأول صلى الله عليه وسلم، على موقع وزارة الأوقاف السعودية.

الثمري، هدى علي جواد. (2003). طرق تدريس التربية الإسلامية، دار الثروق للنشر ورالتوزيع، عمان، الأردن. 
الثناوي، محمد محروس. (1998). العلاج السلوكي الحديث، دار قباء، القاهرة.

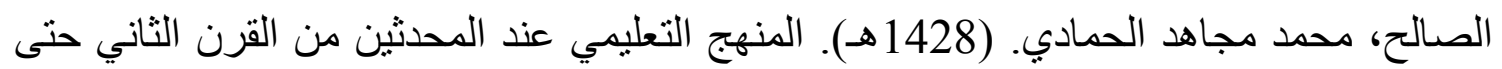
القرن الر ابع، رسالة ماجستير, الجامعة الإسلامية المدينة المنورة.

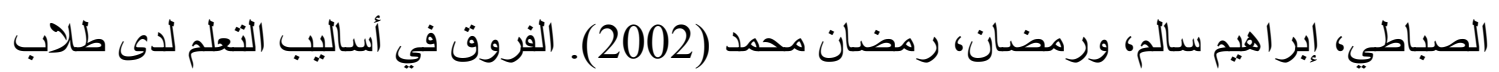

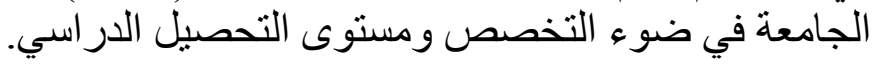
الصباغ، محمد لطفي. (1403 هـ). التصوير الفني في الحديث النبوي ،بيروت فئوي : المكتب الإسلامي.

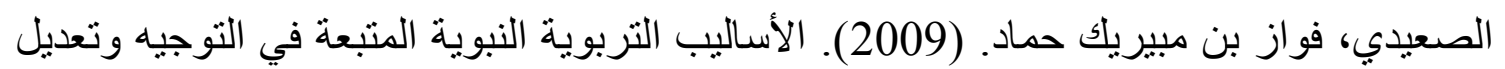

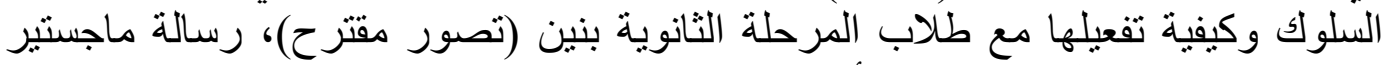

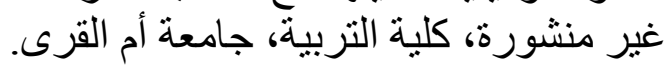

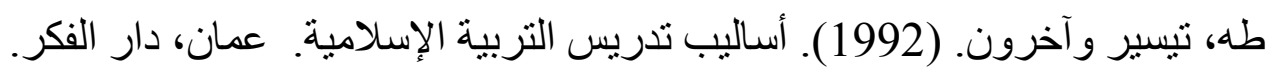
عبد القادر، أحمد عبد القادر. (1420هـ). القصص النبوي، مجلة المستقبل العدد 93، محرم.

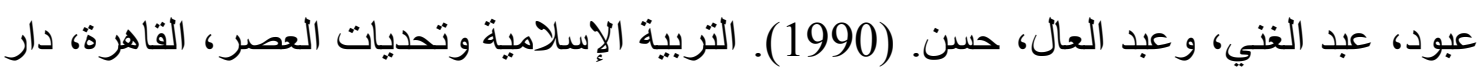

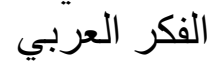

عبيدات، ذوقان. (1424هـ). البحث العلمي، جدة، إثر اقات. العجمي، محمد عبد السلام وآخرون. (1425هـ). تربية الطفل في الإسلام النظرية والترات التطبيق.

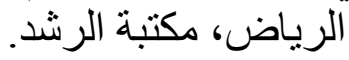

العقلاني، أحمد علي. (1986). فتح الباري صحيح بشرح صحيح البخاري، ط3، الدكتبة السلفية

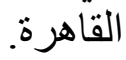

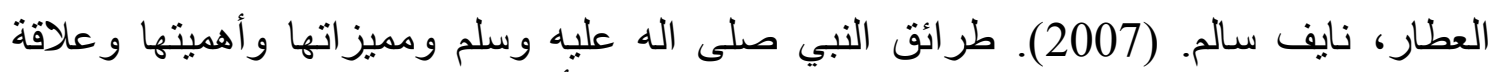

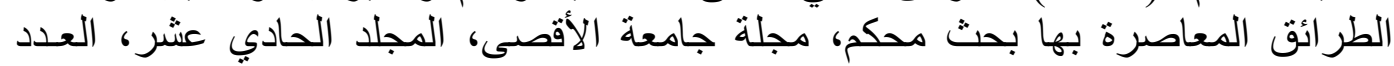

العودة، سلمان بن فهـ. (1424 هـ). أدب الحوار، الرياض، العبيكان.

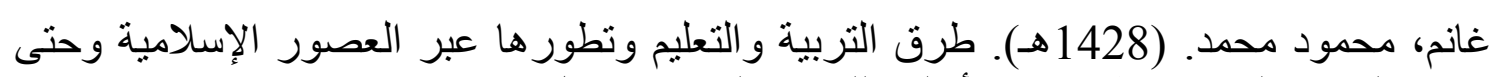
العصر الحديث، ط1، دار الأندلس للنشر و التوزيع، حائل.

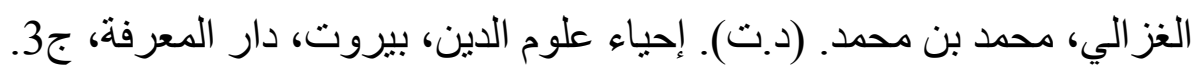

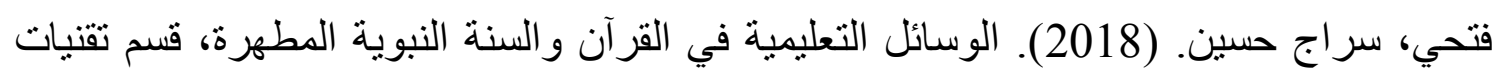

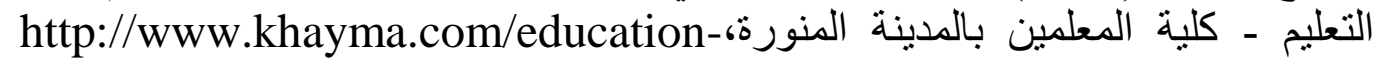
technology/w3.htm

القرني، غازي بن محمد بن دميس. (1424هـ). أساليب النبي صلى الله عليه وسله وسلم في عملية الضبط الاجتماعي وتطبيقاتها في الواقع المعاصر، رسالئ رسالة ماجستير غير منشورة، كلية

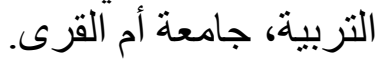

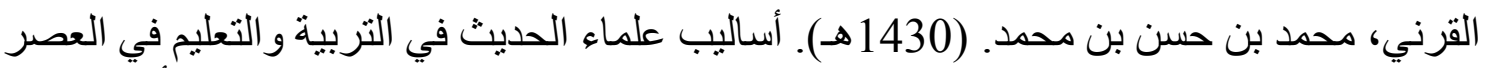

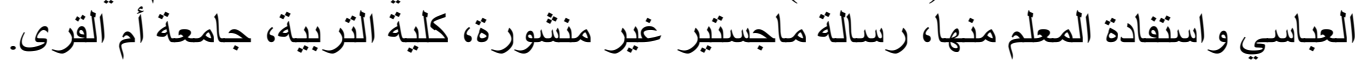
قطب، محمد. (1417هـ). ركائز الإيمان. الرياض، دار اشبيليا للنشر و التوزيع. 
قطب، محمد. (2011). منهج التربية الإسلامية، دار الشروق، ط14، جـ جات 2.

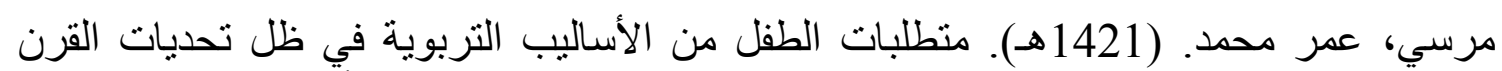
الحادي والعشرين، رسالة ماجستير غير منشورة، كلية التربية، قسم أصول التربية لتربية، جامعة الترنة

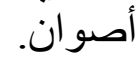

مطاو ع، إبراهيم، و عزيز واصف. (1406هـ). التربية العملية وأسس طرق التدريس، دار النهضة

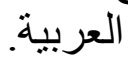

معلم، وسيم عبد الرحمن محمد. (1429 هـ). الأساليب التربوية لتعظيم البلد الحر ام لطلاب المرحلة

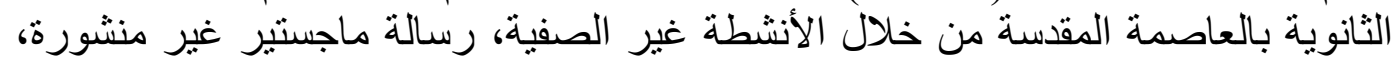
كلية التربية، جامعة أم القرى.

المقدس، محمد بن مفلح. (1417 هـ). الآداب الشر عية، تحقيق شعيب الأرنؤوطو وعر القيام، ط2، بيروت، مؤسسة الرسالة.

الميداني، عبد الرحمن حسن. (1413هـ). الأخلاق الإسلامية، ط2، دمثق، دار العلم، ج1.

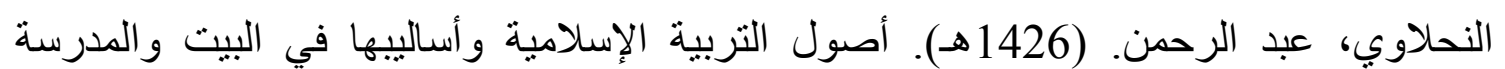
و وألمجتمع، ط23، دمشق، دار الفكر.

النووي، محي الدين أبي زكريا يحي بن شرف، دمن. (1423 هـ). رياض الصالحين، ط3، دار الزمان

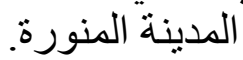

